\title{
Modeling of Hydrologic Conditions and Solute Movement in Processed Oil Shale Waste Embankments Under Simulated Climatic Conditions
}

\section{Topical Report}

Tim L. Reeves

John P. Turner

Victor R. Hasfurther

Quentin D. Skinner

Work Performed Under Contract No.: DE-FC21-86LC11084

\author{
For \\ U.S. Department of Energy \\ Office of Fossil Energy \\ Morgantown Energy Technology Center \\ P.O. Box 880 \\ Morgantown, West Virginia 26507-0880 \\ By \\ University of Wyoming \\ Department of Range Management \\ P.O. Box 3354 \\ Laramie, Wyoming 82071-3354
}

June 1992 


\section{Table of Contents}

1.0 Introduction ............................................................................................. 1

1.1. Executive Summary …................................................................... 2

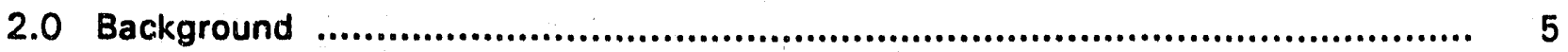

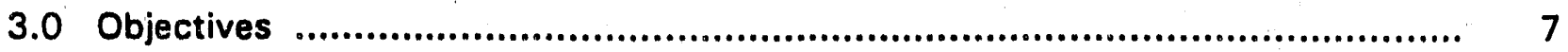

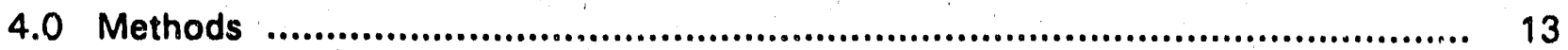

4.1 Description of Study Sites _................................................................. 13

4.1.1 Rio Blanco Oil Shale Co., Tract C-a .......................................... 13

4.1.2 Environmental Simulation Laboratory ......................................... 14

4.2 Bench Scale Research Program .......................................................... 16

4.2.1 Leachate Chemistry _................................................................ 16

4.2.2 Geotechnical and Hydrologic Properties ..................................... 17

4.3 Lysimeter Testing Program ............................................................... 21

4.3.1 Placement of Shale and Instrumentation in Lysimeters .................... 23

4.3.2 Coring Program for Geotechnical and Chemical Analysis ................ 26

4.3.3 Leachate Chemistry and Flux .................................................. 27

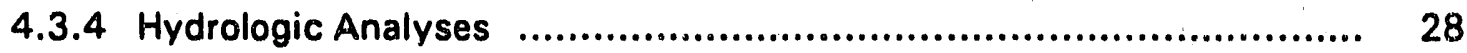

4.3.5 Stress Testing ..................................................................... 32

4.4 Computer Modeling Program ............................................................ 33

4.4.1 Hydrologic Modeling ............................................................... 33

4.4.2 Geotechnical Modeling ............................................................. 34

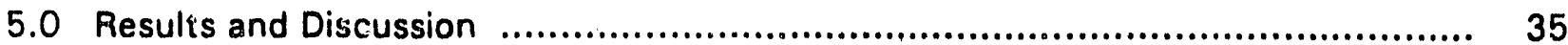

5.1 Bench Scale Research Program ..................................................... 35

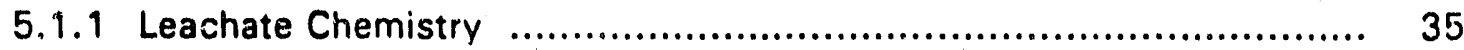




\section{Table of Contents (Continued)}

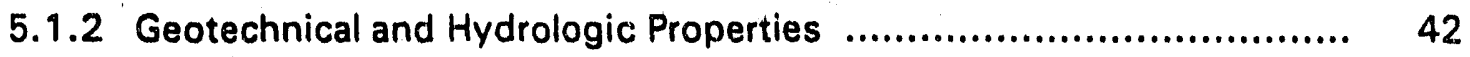

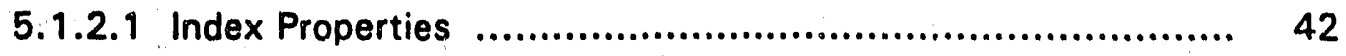

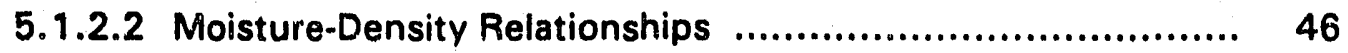

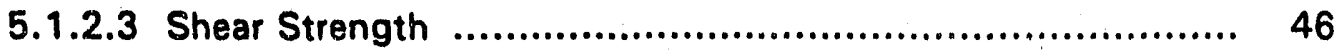

5.1.2.4 Hydraulic Conductivity .......................................... 51

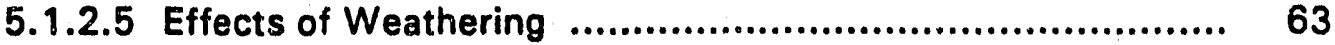

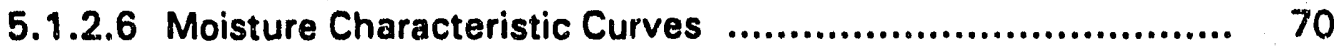

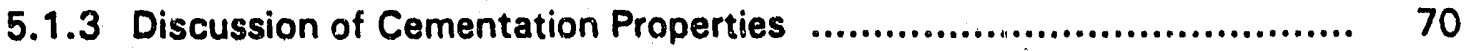

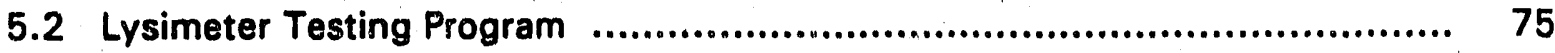

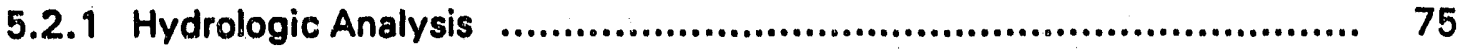

5.3 Computer Modeling Program .................................................. 87

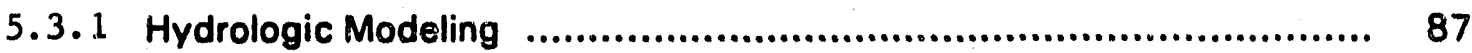

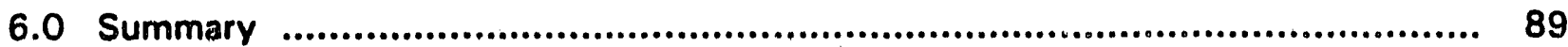

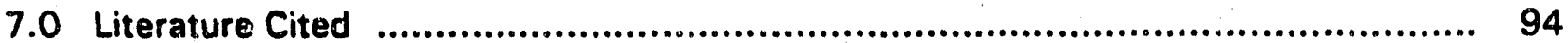




\section{List of Figures}

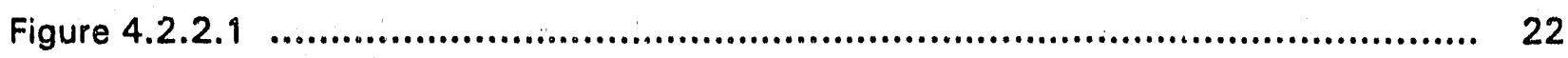

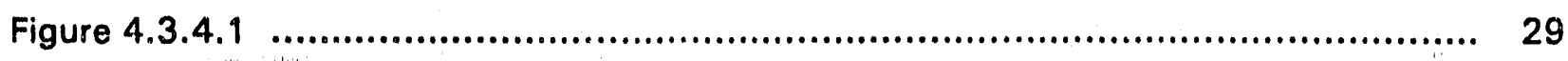

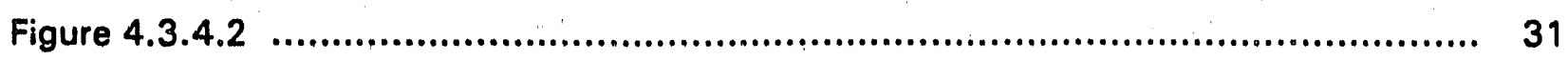

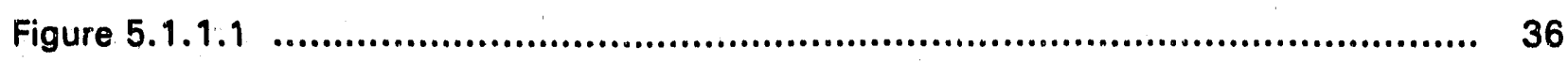

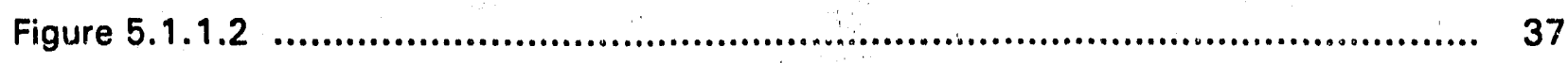

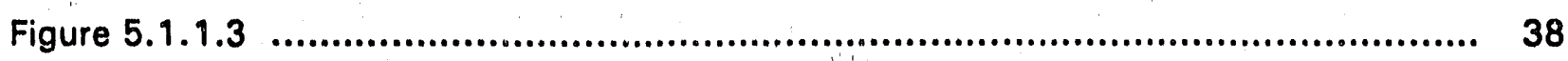

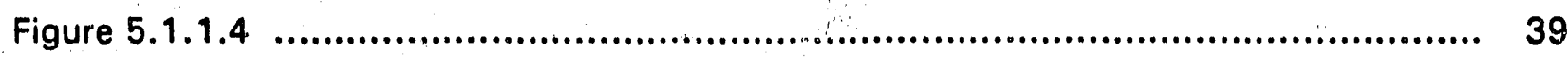

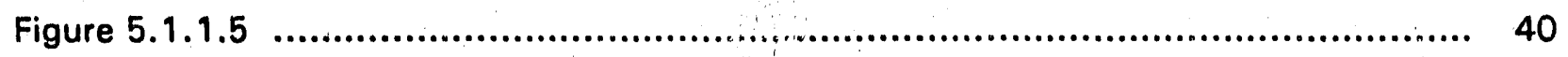

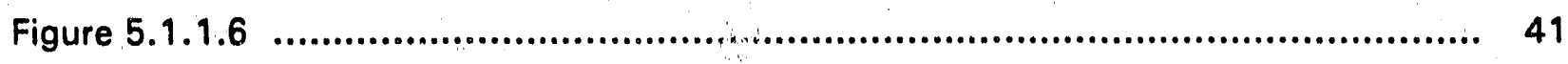

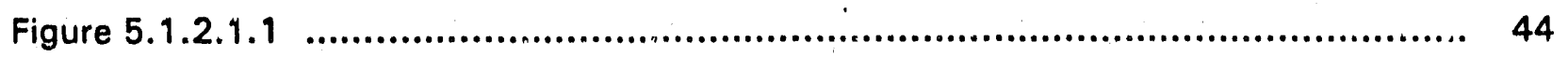

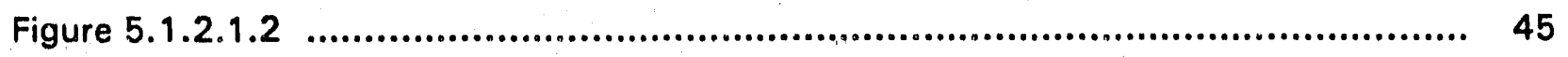

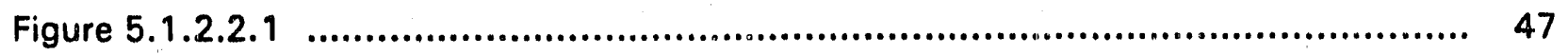

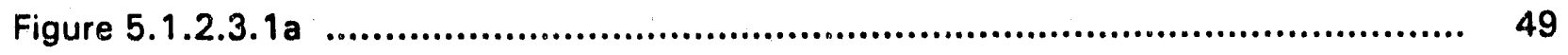

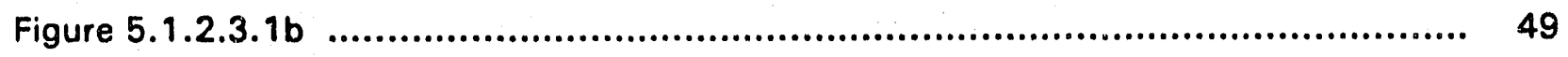

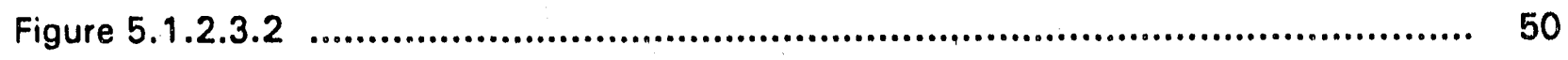

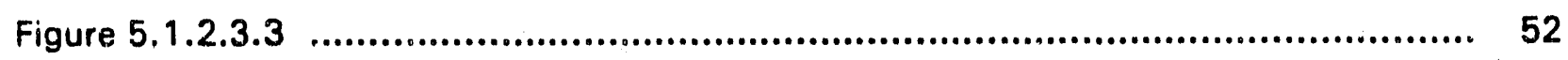

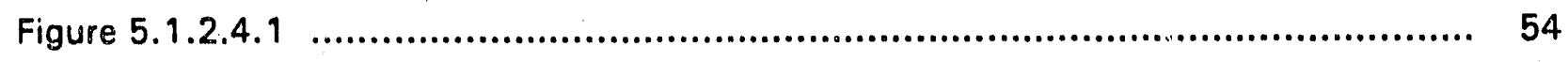

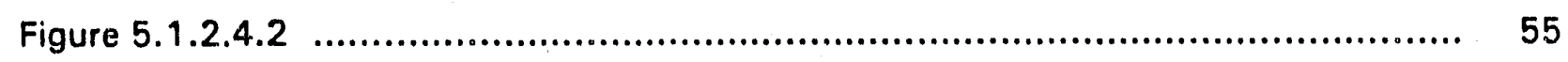

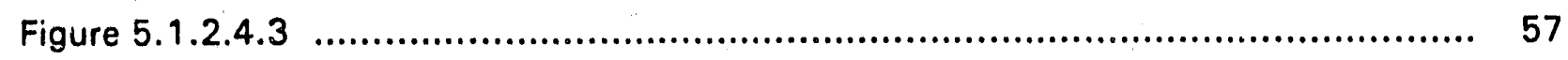

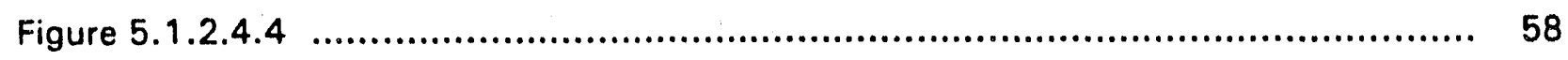

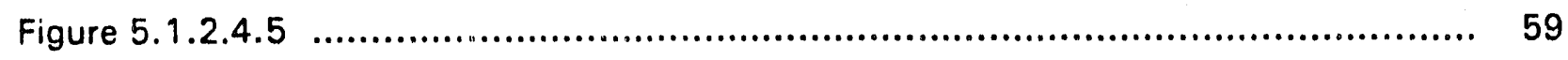

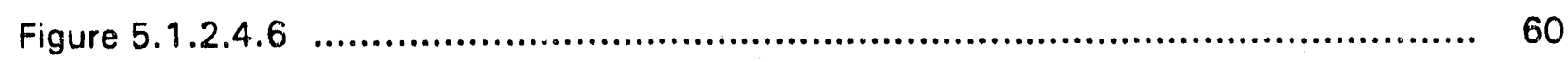

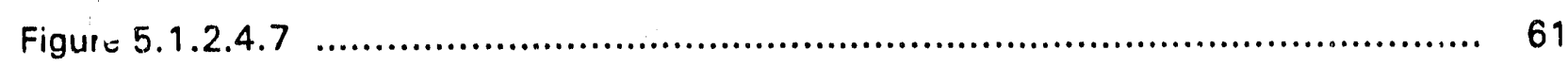




\section{List of Figures (Continued)}

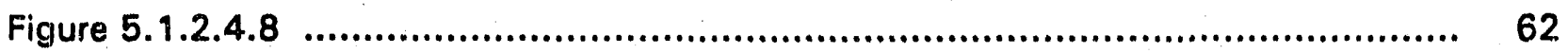

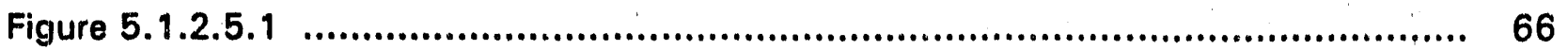

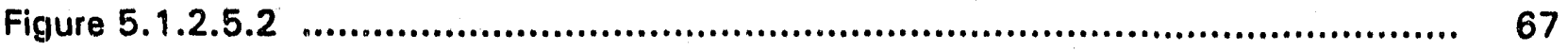

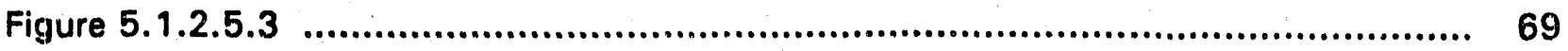

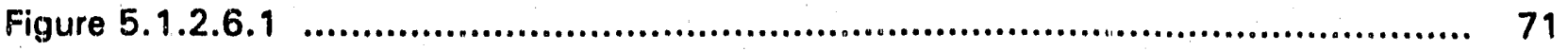

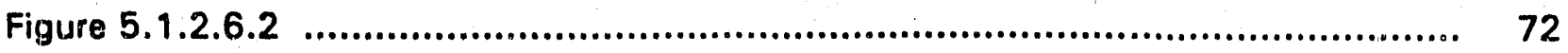

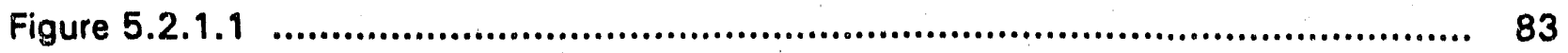

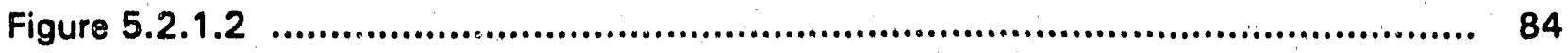

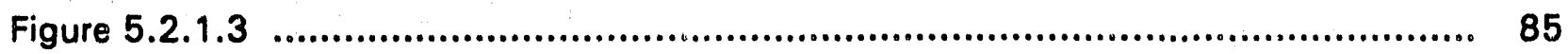

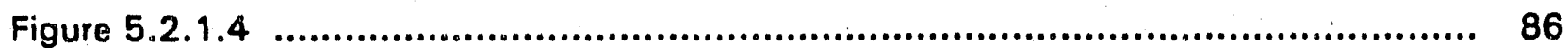




\section{List of Tables}

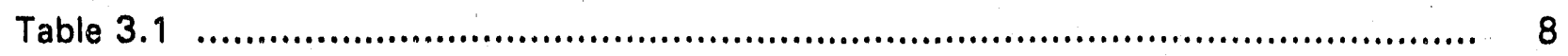

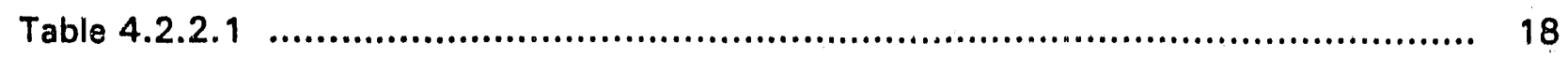

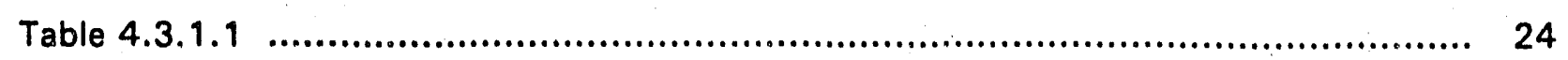

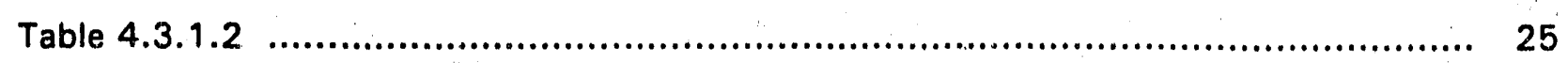

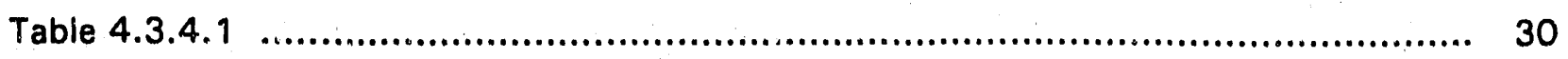

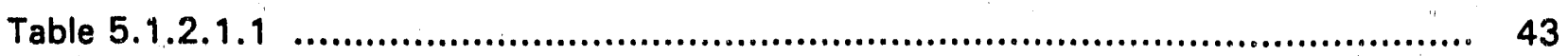

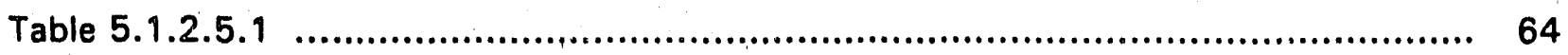

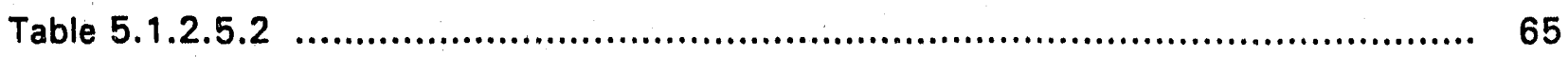

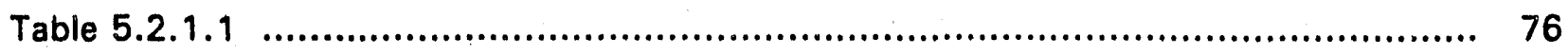

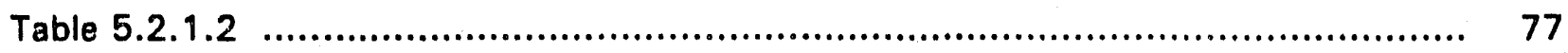

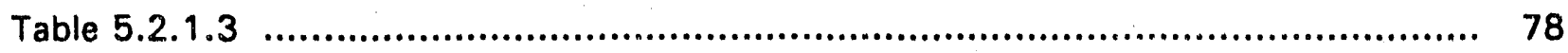

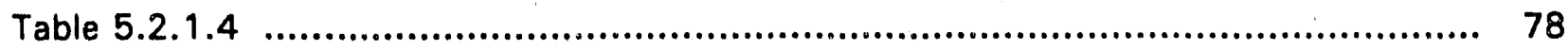

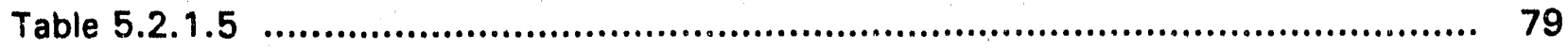

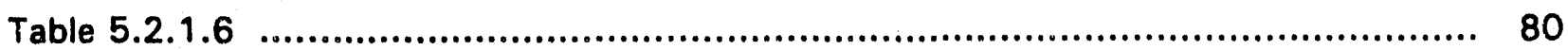

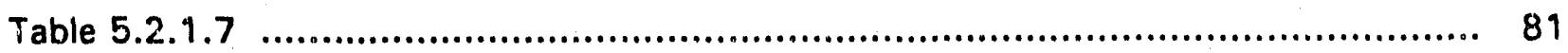

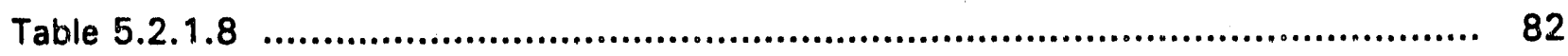

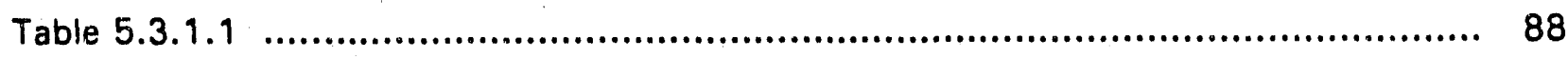




\subsection{INTRODUCTION}

This research program was initiated in 1986 under a Cooperative Agreement between the U.S. Department of Energy, Laramie Projects Office and the University of Wyoming (UW), Contract Number DE-FC21-86LC1 1084. Cooperative agreements were also established between the University of Wyoming and Rio Blanco Oil Shale Co., Inc. (RBOSC) in 1987 and between the University of Wyoming and Exxon USA, Colony Shale Oil Project, in 1988.

The scope of this program is to study interacting hydrologic, geotechnical, and chemical factors affecting the behavior and disposal of combusted processed oil shale. The research combines bench-scale resting with large-scale testing sufficient to describe commercial-scale embankment behavior. The large-scale testing was accomplished by constructing five lysimeters, each $7.3 \times 3.0 \times 3.0 \mathrm{~m}$ deep, filled with processed oil shale that has been retorted and combusted by the Lurgi-Ruhrgas (Lurgi) process (Schmalfield 1975). Approximately 400 tons of Lurgi processed oil shale waste was provided by RBOSC to carry out this study.

Three of the lysimeters were established at the RBOSC Tract C-a in the Piceance Basin near Rifle, Colorado. Two lysimeters were established in the Environmental Simulation Laboratory (ESL) at UW. The ESL was specifically designed and constructed so that a large range of climatic conditions could be physically applied to the processed oil shale which was placed in the lysimeter cells. A detailed description of this facility is presented in section 4.1.

This report discusses and summarizes results from scientific efforts conducted between October 1986 and March 1991. The original cooperative agreement between UW and DOE was modified and extended until 1993. This is interim report which presents final results from tasks which have been concluded to date, and partial/interim results from tasks still in progress or partially completed. 


\subsection{EXECUTIVE SUMMARY}

The scope of this program is to study interacting hydrologic, geotechnical, and chemical factors affecting the behavior and disposal of combusted processed oil shale. The research combines bench-scale testing with large scale research sufficient to describe commercial scale embankment behavior. The large scale approach was accomplished by establishing five Iysimeters, each $7.3 \times 3.0 \times 3.0 \mathrm{~m}$ deep, filled with processed oil shale that has been retorted and combusted by the Lurgi-Ruhrgas (Lurgi) process (Schmalfield 1975). Approximately 400 tons of Lurgi processed oil shale waste was provided by RBOSC to carry out this study.

Three of the lysimeters were established at the RBOSC Tract C-a in the Piceance Basin near Fifle, Colorado. Two lysimeters were established in the Environmental Simulation Laboratory (ESL) at UW. The ESL was specifically designed and constructed so that a large range of climatic conditions could be physically applied to the processed oil shale which was filled in the lysimeter cells. A detailed description of this facility is presented in section 4.1.

Research objectives were designed to evaluate hydrologic, geotechnical, and chemical properties and conditions which would affect the design and performance of large-scale emban ants. The objectives of this research are:

- Assess the unsaturated movement and redistribution of water and the development of potential saturated zones and drainage in disposed processed oil shale under natural and simulated climatic conditions.

- Assess the unsaturated movement of solubles and major chemical constituents in disposed processed oil shale under natural and simulated climatic conditions. 
- Assess the physical and constitutive properties of the processed oil snale and determine potential changes in these properties caused by disposal and weathering by natural and simulated climatic conditions.

- Assess the use of previously developed computer model(s) to describe the infiltration, unsaturated movement, redistribution, and drainage of water in disposed processed oil shale.

- Evaluate the stability of field scale processed oil shale solid waste embankments using computer models.

This is an interim project report which presents final results from tasks and objec ives which have been concluded to date, and partial/interim results from tasks still in progress or partially completed. A final report of the project will be developed upon completion of Amendment AOO8 in March 1993.

Results from the bench-scale research program, primarily designed to describe the initial physical, chemical and hydrologic properties of the Lurgi processed oil shale, are principally complete and presented in this report. These data include potential leachate chemistry, mechanical and constitutive properties such as grain size distribution, Atterberg limits, moisture density relationships, shear strength, and saturated and unsaturated hydraulic conductivity.

Results which have been presented in this report from the large-scale lysimeter research program and the computer modeling research program are interim or partially complete at this date. These data include in situ hydrologic analyses for infiltration, flux and hydraulic properties, in situ chemical analyses, in situ stress analysis, and those from the computer model research program. Final results from these research programs are dependent on completion of all in situ 
tests and the inal destructive sampling of the processed shale in the lysimeters at the conclusion of the research program. 


\subsection{BACKGROUND}

The development of a mature oil shale industry in the United States will largely depend on technology development for the solid waste disposal of processed shale in a manner that is physically stable, prevents or minimizes the release of toxic or potentially toxic compounds to the anvironment, and provides an economically acceptable post land use. The licensing of a commercial oil shale operation to dispose of processed oil shale in a surface embankment will require accurate estimates of the physical stability of the proposed embankment, including the petential risk of failure (safety factors), estimates of the potential release of pollutants to the environment, including surface and ground water systems, the rate of release of such pollutants, and changes in these processes or environmental impacts with time (Reeves et al. 1986).

A detailed knowledge of soil water behavior within a processed oil shale embankment is of primary importance to the design of a physically and chemically stable waste embankment. Geotechnical design and knowledge of the movement of potentially toxic salts and other solubles is primarily dependent on the accurate measuiement of water infiltration, flux, direction, and velocity in both saturated and unsaturated zones.

Many hydrological, geotechnical, chemical, and environmental processes associated with processed oil shale waste embankments will be estimated by computer models. Estimates produced by these models will be used to modify or create embankment designs to meet federal and state regulatory performance criteria, or to analyze existing embankments for performance. Unfortunately, the licensing of a commercial-scale embankment may have to be strongly based on estimates made from computer models regarding performance. This would be especially true for the performance evaluation of time dependant variables. It is necessary, therefore, that developed computer models that are used to estimate the hydrologic, geochemical, or 
geotechnical properties of engineered embankments be verified and tested by field and laboratory research, physical models, embankment prototypes, etc. (Reeves et al. 1986). 


\subsection{OBJECTIVES}

The purpose of this research is to physically model, study, and describe the hydrologic, geotechnical, and chemical properties associated with the disposal of processed oil shale in large embankments. A primary effort of this program is the study of the redistribution and mov'ement of water and percolates in disposed processed oil shale and to evaluate the use of developed computer models to describe these processes. Research objectives were designed to evaluate hydrologic, geotechnical, and chemical properties and conditions which would affect the design and performance of large-scale embankments. The objectives of this research are:

- Assess the unsaturated movement and redistribution of water and the development of potential saturated zones and drainage in disposed processed oil shale under natural and simulated' climatic conditions.

- Assess the unsaturated movement of solubles and major chemical constituents in disposed processed oil shale under natural and simulated climatic conditions.

- Assess the physical and constitutive properties of the processed oil shale and determine potential changes in these properties caused by disposal and weathering by natural and simulated climatic conditions.

1 Simulated climatic regimes refer to those created and produced in the Environmental Simulation Laboratory (ESL). 
- Assess the use of previously developed computer model(s) to describe the infiltration, unsaturated movement, redistribution, and drainage of water in disposed processed oil shale.

- Evaluate the stability of field scale processed oil shale solid waste embankments using computer models.

Table 3.1 provides an outline of detailed sub-objectives (tasks) associated with the above stated main objectives for this research program.

\section{Table 3.1. Research objectives.}

\section{OBJECTIVE 1.0}

Assess the unsaturated movement and redistribution of water and the development of potential saturated zones and drainage in disposed processed oil shale under natural and simulated climatic conditions.

1.1 Determine initiai saturated and unsaturated hydraulic properties for the processed oil shale and describe effects caused by hysteresis and by changes in exchangeable sodium percentage which could occur through leaching.

1.2 Determine infiltration rates of precipitation into disposed processed oil shale lifts and describe the effiects caused by storm duration, storm intensity, antecedent water content by profile depth, and the vertical hydraulic gradient. 


\section{Table 3.1 Research Objectives (Continued).}

1.3 Determine the distribution of soil moisture as a function of profile depth and time and evaluate changes in storage with time.

1.4 Determine the cumulative flux of water and direction as a function of profile depth and time.

1.5 Deterinine saturated and unsaturated hydraulic properties for processed ail shale after disposal and weathering under climatic conditions.

1.6 Assess differences in the measured hydraulic properties from 1.1 and 1.5 above.

\section{OBJECTIVE 2.0}

Assess the unsaturated movement of solubles and major chemical constituents in disposed processed oil shale under natural and simulated climatic conditions.

2.1 Determine the initial chemical composition and total quantity of solubles present in the processed oil shale.

2.2 Determine the distribution of solubles and analyze the major chemical constituents as a function of profile depth and time during the operation of field and laboratory Iysimeters. 


\section{Table 3.1 Research Objectives (Continued).}

2.3 Determine the cumulative flux and direction of movement of solubles as a function of profile depth and time during climatic simulation.

2.4 Determine the final chemical composition and total quantity of solubles remaining as a function of profile depch in the processed oil shale after completion of disposal and weathering by climatic simulation.

\section{OBJECTIVE 3.0}

Assess the physical and constitutive properties (index properties, shear strength, stressstrain properties and compressibility) of the processed oil shale and determine potential changes in these properties caused by disposal and weathering by natural and simulated climatic conditions.

3.1 Determine the initial ohysical and constitutive properties of the processed oil shale.

3.2 Determine the physical and constitutive properties of the processed oil shale as a function of profile depth in the lysimeters during and after completion of weathering by simulated climatic conditions.

3.3 Assess any measured differences between the initial and final physical and constitutive properties of the processed oil shale solid waste after being subjected to natural and simulated climatic conditions. 


\section{Table 3.1 Research Objectives (Continued).}

3.4 Evaluate relationships between the physical and constitutive properties of processed oil shale and its chemical/mineralogical characteristics.

3.5 Determine the strength and stress-strain properties of oil shale solid waste under dynamic loading conditions.

\section{OBJECTIVE 4.0}

Assess the use of previously developed computer model(s) to describe the infiltration, unsaturated movement, redistribution, and drainage of water in disposed processed oil shale:

4.1 Assess differences between measured physical data observed in the lysimeters and data estimated by computer model under the boundary conditions and simulated climatic conditions which were applied to the lysimeter plots.

\section{OBJECTIVE $\mathbf{5 . 0}$}

Evaluate the stability of field scale processed oil shale solid waste embankments using computer models.

5.1 Obtain and evaluate commercially available computer codes that will enable realistic evaluation of embankment stresses, deformations, and factors of safety against slope instability. 


\section{Table 3.1 Research Objectives (Continued).}

5.2 Model the stability behavior of processed oil shale solid waste embankments, taking into account the construction, adjustment, long-term and transient stages of embankment service life. 


\subsection{METHODS}

\subsection{DESCRIPTION OF STUDY SITES}

\subsubsection{RIO BLANCO OIL SHALE CO., TRACT C-a.}

A cooperative agreement waș established between Rio Blanco Oil Shale Co., Inc. (RBOSC) and the University of Wyoming in July 1987. This cooperative agreement established that RBOSC would provide approximately 400 tons of processed oil shale that had been retorted and combusted by the Lurgi-Ruhrgas (Lurgi) process (Schmalfield 1975). This test source of processed oil shale came from RBOSC test operations at Tract C-a in the Piceance Basin of Colorado. Tract C-a was established by RBOSC, a subsidiary of Amoco, as a pilot scale oil shale mine and in situ retort test location. Tract C-a would also be RBOSC's location for a full scale oil shale operation if technology development and economic conditions allotted. The cooperative agreement established that approximately 200 tons of the Lurgi processed shale would be utilized by constructing three field lysimeters at Tract $C-a$. The remaining 200 tons would be shipped to UW to be used for bench-scale testing and to establish two lysimeters in the Environmental Simulation Laboratory.

RBOSC designed and engineered three field lysimeters working with the recommendations of UW personnel and based on the RBOSC objectives for the study. The lysimeters were also designed to be the same size as the two lysimeter cells designed and proposed for the ESL at UW. The fie!d lysimeters were constructed of plywood, timbers, and steel. The cells were excavated into a natural embankment at Tract $\mathrm{C}$-a. The hillside design allowed for easy placement of the processed oil shale into the lysimeter cells and provided the top of the cells to match the normal landscape at the top of the embankment. 


\subsubsection{ENVIRONMENTAL SIMULATION LABORATORY}

The Environmental Simulation Laboratory (ESL) was designed by McFall, Konkel and Kimball, an architectural engineering firm located in Cheyenne, Wyoming, according to requirements and recommendations specified by the UW project personnel. The ESL design was complete in December 1987 and bids for contracting the construction were taken and accepted by UW in January 1988.

The ESL consists of an environmental chamber which is a $7 \times 6 \mathrm{~m}$ closed room constructed of environmental freezer panels, lysimeter cells, and a computer driving system. The chamber houses two lysimeter cells each $7.3 \times 3.0 \times 3.0 \mathrm{~m}$ deep. The environment inside the chamber is precisely controlled for ambient temperature, relative humidity, rainfall, and radiant flux by computer. Construction materials for the ESL were all available commercially.

The freezer panels of the environmental chamber consist of an interior sheet of stainless steel, a middle layer of insulating foam, and an outside layer of porcelain. The stainless steel coating was chosen for the inside of the panels to provide chemical resistance. The insulating foam on the inside of the panel was chosen over fiberglass type layers which were also available. The foam insulation resists ice build up during freezing temperatures.

The lysimeter cells are constructed of concrete, insulated on the interior side with tapered foam sheets, providing a greater thickness at the bottom of the chamber. The tapered design was used to aid soil materials with expansive properties during wetting or freeze-thaw cycles to expand upward and not create horizontal loads against the concrete walls of the cells.

The environmental control system is designed to produce rapid changes in temperature and control relative humidity at a wide range of temperatures. The air throughput is driven by a ten horsepower fan that can use outside air providing an open system, or continuously recirculate the air for a closed system. The system throughput is 40 complete air exchanges per hour. The 
precision with which temperature and humidity is controlled is maximized by operating the ESL as a closed system.

Environmental conditions are adjusted through the use of two-phased air conditioning, freezing, and heating units. A steam generator raises relative humidity in the system. Dehumidification is accomplished through the air conditioning and freezing system. The high throughput of the system provides excellent precision in temperature and humidity control and provides fast responses to desired changes in temperature and humidity. Ambient chamber temperatures can be regulated between $-29^{\circ} \mathrm{C}$ to $48^{\circ} \mathrm{C} \pm 2^{\circ}$.

Relative humidity can be generally regulated from $30 \%$ to $90 \% \pm 5 \%$ at all temperatures between $-29^{\circ} \mathrm{C}$ and $48^{\circ} \mathrm{C}$. Control becomes more difficult near the temperature extremes. As ambient temperatures approach $-29^{\circ}$ the system has difficulty lowering relative humidity below $30 \%$. As ambient temperatures approach $48^{\circ}$ the system has difficulty maintaining relative humidity above $90 \%$. The system easily regulates relative humidity between $20 \%$ and $95 \%$ at temperatures between $0^{\circ}$ and $32^{\circ} \mathrm{C}$.

Lighting is provided by 24 metal halide lights that produce solar radiant flux between 0 and $53,000 \mathrm{Im} / \mathrm{m}^{2}$ intensity. The lights are located eight feet above the surface of the lysimeter plots. The total radiant flux is approximately $80 \%$ of that of natural sunlight at sea level. The light quality is between 390 to $700 \mathrm{~nm}$ wavelength and is proportioned to be adequate for plant growth. Desired intensity levels are regulated by controlling the number of lights that are on at any given time. The lighting of individual lights is randomly rotated by the computer system to provide an even distribution of flux over the plot surface.

Rainfall can be produced at rates between 0 and $127 \mathrm{~mm} / \mathrm{hr}$ by Lafayette ${ }^{2}$ rainfall simulators. The simulators were designed and constructed by personnel at Lafayette and

2 Designed at the United States Department of Agriculture Science and Education Administration (USDA-SEA) Erosion Research Unit, Lafayette, Indiana. 
shipped to UW in 1988. Research performed at Lafayette has shown that these simulators produce a distribution of raindrop sizes that is similar to that of runoff producing storms in the midwest region of the U.S. Raindrop size distribution does not change with different rainfall intensities, and the energy of terminal velocity. Electronic systems, a computer controlled driver, and a computel rainfall modeling program were developed for the rainfall simulators at UW for

use in the ESL. Using the computer system, rainfall hyetographs (i.e. a rainfall time-intensity distribution) are designed, modeled, and physically applied in the ESL. A more detailed description of the rainfall simulation system and programs are presented by Reeves (1989).

\subsection{BENCH-ISCALE RESEARCH PROGRAM}

The solid waste product resulting from the Lurgi-Ruhrgas process consists of two materials, solids collected in surge bins and dust collected in flue filters. The surge bin solids, which are coarser than the flue dust, comprise approximately 90 percent by weight of the material. A $90 / 10$ ratio of the Lurgi surge bin solids to flue filter dust was used for all bench scale tests and analyses.

\subsubsection{LEACHATE CHEMISTRY}

A column leaching syst $1: m$ was designed and constructed to determine the initial chemical composition anid quantity of solubles present from the unweathered Lurgi processed oil shale (Objective 2.1). The system consisted of four columns, which each could hold a $3.6 \mathrm{~cm}$ diameter by $7.1 \mathrm{~cm}$ high cylindrical specimen. This allowed samples or specimens to be prepared using a Harvard miniature apparatus. This apparatus consists of a cylindrical mold 3.6 $\mathrm{crn}$ in diameter and $7.1 \mathrm{~cm}$ high and a $201 \mathrm{~b}$ spring loaded compaction hammer. Each sample was compacted in five lifts using ten blows per lift. Prepared specimens were held in the 
apparatus using a flexible wall system. Specimens are enclosed by a flexible latex membrane and placed into the individual chambers of the apparatus. The chambers are pressurized to confine and hold the enclosed specimens. An influent reservoir, containing distilled water, was also pressurized to provide flow through the specimens or samples. Different flow rates (i.e. leaching rates) could be achieved by varying the pressure of the influent reservoir.

Two sets of samples, each set consisting of four specimens, were prepared using the Harvard miniature apparatus at water contents of 15 and 20 percent by weight. Following compaction, samples were extruded from the mold, sealed in plastic cellophane, and stored in a wet room for 1 week to cure. This was necessary because of the cementation reactions which occur in the Lurgi shale from wetting.

Using the leaching apparatus, samples were permeated with distilled water at a $138 \mathrm{kPa}$ differential gradient with a $172 \mathrm{kPa}$ confining pressure. Twenty-five $\mathrm{ml}$ of leachate was collected from each sample every $125 \mathrm{ml}$ of total leachate produced. Twenty-five $\mathrm{ml}$ represented approximately 1 pre volume. In effect, 1 pore volume was collected for analysis on every $5^{\text {th }}$ pore volume of leachate that was produced.

Leachate samples wore analyzed to determine concentrations of sodium, chloride, sulfate, magnesium, calcium, and total alkalinity. EPA standard procedures were used for all chemical analyses.

\subsubsection{GEOTECHNICAL AND HYDROLOGIC PROPERTIES}

A laboratory testing program was carried out to determine the geotechnical properties of combusted oil shale that are pertinent to the design of solid waste disposal embankments (Table 4.2.2.1). The testing program consisted of index properties, moisture density relationships (compaction tests), consolidated-drained and consolidated-undrained triaxial tests, unconfined compression tests (Objective 3.1). Permeability tests and tests to determine moisture-character- 
istic curves were also conducted (Objective 2.1). In addition, samples of processed shall were weathered artificially to evaluate the potential influence of wet-dry and freeze-thaw cycles on strength and hydraulic conductivity. ASTM standards were followed for all testing procedures, where applicable. Further details are given by Pothwell (1989).

Table 4.2.2.1 Summary of geotechnical laboratory testing program.

\begin{tabular}{llc}
\hline \multicolumn{1}{c}{ Property } & \multicolumn{1}{c}{ Tests } & No. of Tests \\
\hline Index propertios & Grain-size distribution & 28 \\
& Atterberg limits & 28 \\
Compaction & Moisture-density relationships & 3 \\
& & \\
Shear strength & CD triaxial & 25 \\
& CU triaxial & 15 \\
& CU triaxial (weathered) & 30 \\
& Unconfined compression & 53 \\
Hydraulic properties & Falling head permeability & 81 \\
& Falling head permeability (weathered) & 64 \\
& Flow pump permeability (weathered) & 64 \\
& Moisture-characteristic curves & 4 \\
\hline
\end{tabular}

To evaluate material variability, 26 samples of surge bin solids were abtained randomly from a source consisting of 454 tonnes. Grain size distribution and Atterberg limits were determined for each sample. In addition, one sample of flue dust (Sample 27) and one sample consisting of 90 percent surge bin solids and 10 percent flue dust (Sample 28) were evaluated for grain size distribution and Atterberg limits. Based on the grain size distribution, the coefficients of uniformity, $c_{u}$ and curvature, $c_{v}$, were determined. These coefficients are defined as:

$$
\begin{aligned}
& c_{u}=D_{00} / D_{10} \\
& c_{c}=\left(D_{30}\right)^{2} /\left(D_{10} \times D_{00}\right)
\end{aligned}
$$


where $D_{10,} D_{30}$ and $D_{B 0}$ are the grain sizes corresponding to 10,30 , and 60 percent passing, respectively.

Atterberg limits testing consisted of liquid limit (LL), plastic limit (PL), and plasticity index (PI). The plasticity index is defined as the difference between the liquid and plastic limits and indicates the range of water contents over which a soll behaves plastically. Based upon grain size distribution and Atterberg limits, each sample was classified according to the Unified Soil Classification System (ASTM 1985).

To evaluate the potential effects of weathering on strength and hydraulic conductivity, samples of hydrated processed shale were subjected to wet-dry and freeze-thaw conditions in accordance with ASTM D 559-82, "Standard Method for Wetting-Drying Tests of Compacted Soil-Cement Mixtures" or ASTM D 560-82, "Standard Method for Freezing-and-Thawing Tests of Compacted Scil-Cement Mixtures" (ASTM 1985). Samples were compacted at either $15 \%$ or $27 \%$ water content $(w / w)$ in special soil-cement molds (ASTM 1985) and were $7.1 \mathrm{~cm}$ in diameter and $14.2 \mathrm{~cm}$ high. Two samples were prepared for each test and then cured for 28 days at $20^{\circ} \mathrm{C}$ and $100 \%$ relative humidity.

In the wet-dry test, the 2 samples were submerged in a water bath for 5 hours. One of the specimens was weighed and measured to determine volume change. The second sample was given 2 firm strokes on all surface areas with a wire scratch brush and then weighed and measured to determine cement loss as a percentage of initial sample weight. Both samples then were placed in an oven at $71^{\circ} \mathrm{C}$ for 42 hours. Twelve such cycles were applied, in accordance with ASTM (1985). In the freeze-thaw test, the 2 samples were maintained at $-23^{\circ} \mathrm{C}$ for 24 hours. One sample was brushed and then both samples were weighed, measured, and placed in a moist room at $20^{\circ} \mathrm{C}$ and $100 \%$ relative humidity for 23 hours. Following the completion of twelve cycles of either wetting-drying or freezing-thawing, the hydraulic conductivity of each 
sample was measured using both the falling head and flow pump methods, followed by a consolidated undrained triaxial compression test.

A soil moisture characteristic curve describes the relationship between soil water content and capillary pressure (commonly referred to as soil or matrix suction). For this study, soil moisture characteristic curves for the processed shale were used to estimate soil suction in the test embankments from in situ water content. The estimated soil suctions were used to evaluate hydraulic gradients in the lysimeters. The estimated hydraulic gradients were then used with measured volumetric flux values to back calculate the hydraulic conductivity of the processed shale according to Darcy's law. This section describes the tests conducted to obtain characteristic curves for the Lurgi processed shale. Back calculation of hydraulic conductivity is described in later sections of this report.

Two devices were used to determine soil moisture characteristic curves. The first consisted of a 15 bar pressure plate extractor, capable of determining the characteristic curve under draining conditions (decreasing water content) for soil suctions ranging from 0 to 15 bars $(1500 \mathrm{kPa})$. The second apparatus consisted of a 2 bar $(200 \mathrm{kPa})$ pressure plate extractor and was used to develop characteristic curves for both draining and filling conditions. This enabled the measurement of hysteresis on the moisture characteristic curve between 0 and 2 bars. Hysteresis can be described as the difference in soil suction between the draining and filling condition at a given water content. Hysteretic effects can occur during one or more draining and filling cycles. Both pressure plates were designed to allow the passage of water up to the rated pressure $(2$ or 15 bars) while restricting the passage of air.

Samples of processed shale prepared at a water content of $15 \%$ by weight were compacted to a dry density of approximately $1.4 \mathrm{~g} / \mathrm{cm}^{3}(89 \mathrm{pcf})$ in molds $5.1 \mathrm{~cm}$ dia. $0.6 \mathrm{~cm}$ high. This is the same dry density that the processed shale was placed in the lysimeters. The 15 bar apparatus could hold 3 pressure plates to accommodate a total of 36 samples. Figure 
4.2.2.1 shows a schematic of the 15 bar apparatus. Thirty-six samples were prepared and placed in the pressure chamber on the porous plates. The pressure chamber was closed, and air pressure corresponding to the desired level of soil suction was applied. Because the plates are yented to atmospheric pressure a hydraulic gradient was created across the samples and the plate. The samples were left in the chamber until an equilibrium water content was achieved. This was determined by observing the water level of an output burette connected to the plate (Figure 4.2.2.1). Two samples were removed from the chamber after achieving the equilibrium level desired. The removed samples were dried at $104^{\circ} \mathrm{C}$ and weighed to determine water content. The chamber was closed and pressure corresponding to the next desired increment of soil suction was applied. This process was repeated at 1 bar increments until measurements were obtained between 0 and 15 bars.

The 2 bar apparatus operated on the same principal as the 15 bar apparatus, except that samples were not removed at each pressure increment. A single sample was used and the volume of water expelled during each increment of increasing pressure (draining) or absorbed by the sample as the pressure is decreased (filling) was measured using a highly sensitive buretite. The water content corresponding to each pressure increment was calculated from the initial water content and the measured volume of water expelled or absorbed by the sample. Foilowing the test, the final water content was measured and used to verify the calculated water contents.

\subsection{LYSIMETER TESTING PROGRAM}

The lysimeter testing program combines the operation and analysis of 5 large sciale lysimeters, each $7.3 \times 3.0 \times 3.0 \mathrm{~m}$ deep. Three lysimeter celis are located at the RBOSC sire in the Piceance Basin of Coloradc. Two lysimeter cells are located at the University of Wyoming and are enclosed by a large scale environmental chamber. The Environmental Simulation Laboratory (ESL) is described in section 4.1. 

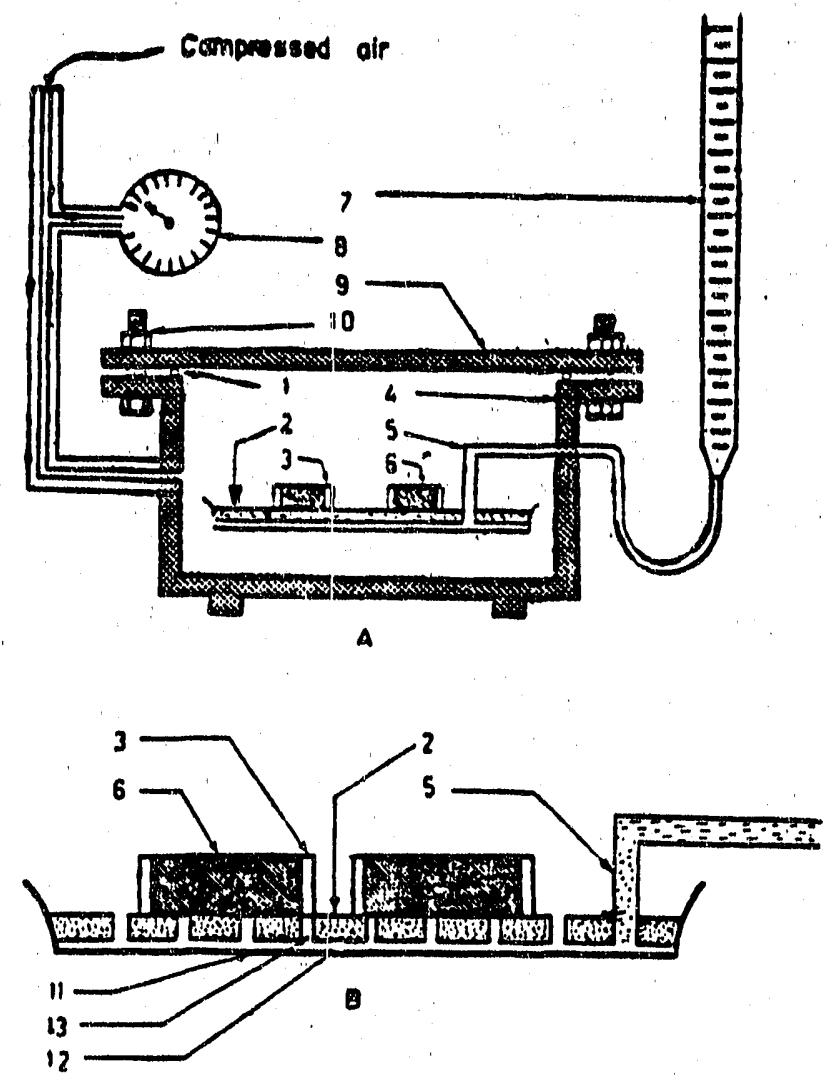

Fig. 7.9 A-Complete pressure plate apparatus B-Pressure plate cell

1. 'a' Pressure seal

2. Ceramic porous plate

3. Sample retaining ring

4. Pressure vessel

5. Outflow tube

6. Soil sample

7. Burette
8. Pressure gauge

9. Vessel lid

10. Clamping bolt

11. Rubber diaphragm

12. Pressure plate cell

13. Water filled pore

Figure 4.2.2.1 15 bar pressure plate apparatus. Source: (Soil Moisture Equipment Co., Inc.) ${ }^{3}$

3 Mention of vendor does not imply an endorsement by the authors or the University of Wyoming. 
A self-logging meteorologic station was installed at the field site. The data logging station could be monitored and accessed via microcomputer at UW. Wind speed at two heights, wind direction, solar radiant flux, ambient temperature, relative humidity, and rainfall depth, duration, and intensity were monitored to give hourly averages. Meteorologic data obtained from this station were used to create the data base to drive the climate in the ESL at UW. In this manner, the climatic conditions which occurred with the lysimeters at the RBOSC site would be repeated at UW in the ESL.

\subsubsection{PLACEMENT OF SHALE AND INSTRUMENTATION IN LYSIMETERS}

Lurgi processed oil shale was placed in the three lysimeters at the RBOSC site in September 1987. Each lysimeter cell represented a different disposal scenario or treatment. Cell 1 was filled with the Lurgi processed oil shale. Cell 2 was filled with a processed oil shale overburden mixture with a $76 \mathrm{~cm}$ soil surface cap. The overburden used was a low grade unprocessed oil shale crushed to 6 inch nominal. The mixture was $60 \%$ by weight of processed oil shale to $40 \%$ overburden. Cell 3 was filled with $61 \mathrm{~cm}$ of straight processed oil shale, 1.8 $m$ of overburden to act as a hydraulic barrier, and $46 \mathrm{~cm}$ of top soil. The processed oil shale for all three cells was mixed to a water content of $15 \%$ by weight in a commercial cement mixer and placed in $30.5 \mathrm{~cm}$ lifts. Lifts were compacted to approximately $1.3 \mathrm{~g} / \mathrm{cm}^{3}$ dry density using a manually driven vibratory compactor. Compactive efforts were not applied to the top soil layers.

Processed oil shale was placed in the two lysimeters of the ESL at UW in October 1989. Cell 1 was filled with the Lurgi processed oil shale. Cell 2 was filled with a processed oil shale overburden mixture. These cells are duplicates to cell 1 and cell 2 at the RBOSC site except that a top soil surface cap was not placed in cell 2. Repeating the methods used at RBOSC, the processed oil shale was mixed to a water content of $15 \%$ by weight in a commercial cement 
mixer and placed in $30.5 \mathrm{~cm}$ lifts. Lifts were compacted to approximately $1.2 \mathrm{~g} / \mathrm{cm}^{3} \mathrm{dry}$ density using a manually driven vibratory compactor.

Instrumentation was installed at various depths in the processed oil shale to monitor water content, total vertical and horizontal stress, and temperature. The instrumentation was installed as the lifts were placed in the lysimeters. Instrumentation was placed in duplicate in the RBOSC Iysimeters and triplicate in the ESL lysimeters. Duplicate aluminum (5 cm dia.) neutron access tubes were installed in each lysimeter cell at both RBOSC and the in the ESL. Tables 4.3.1 and 4.3.2 lists the depths for instrumentation placed in the processed oil shale at RBOSC and in the ESL. respectively.

Table 4.3.1.1 Instrument locations by depth $(\mathrm{cm})$ at RBOSC.

\begin{tabular}{|c|c|c|c|}
\hline $\begin{array}{l}\text { Lysimeter } \\
\text { Cell }\end{array}$ & TDR & $\begin{array}{r}\text { Thermo- } \\
\text { couple }\end{array}$ & Load Cell \\
\hline $\begin{array}{l}\text { RBOSC } \\
\text { Tract C-a } \\
\text { Lysimeter } 1\end{array}$ & $\begin{array}{r}15 \\
30 \\
46 \\
61 \\
76 \\
168 \\
259 \\
290\end{array}$ & $\begin{array}{r}15 \\
30 \\
46 \\
\\
76 \\
168 \\
259\end{array}$ & $\begin{array}{r}76 \\
168 \\
259\end{array}$ \\
\hline $\begin{array}{l}\text { RBOSC } \\
\text { Tract C-a } \\
\text { Lysimeter } 2\end{array}$ & $\begin{array}{r}15 \\
46 \\
76 \\
91 \\
107 \\
168 \\
259 \\
290\end{array}$ & $\begin{array}{c}15 \\
46 \\
76 \\
\\
107 \\
168 \\
259\end{array}$ & $\begin{array}{l}168 \\
259\end{array}$ \\
\hline $\begin{array}{l}\text { RBOSC } \\
\text { Tract C-a } \\
\text { Lysimeter } 3\end{array}$ & $\begin{array}{l}15 \\
30 \\
46\end{array}$ & $\begin{array}{l}15 \\
30 \\
46\end{array}$ & \\
\hline & $\begin{array}{l}259 \\
289\end{array}$ & $\begin{array}{l}259 \\
289\end{array}$ & 289 \\
\hline
\end{tabular}




\section{Iable 4.3.1.2 Instrument locations by depth (cm) at UW-ESL.}

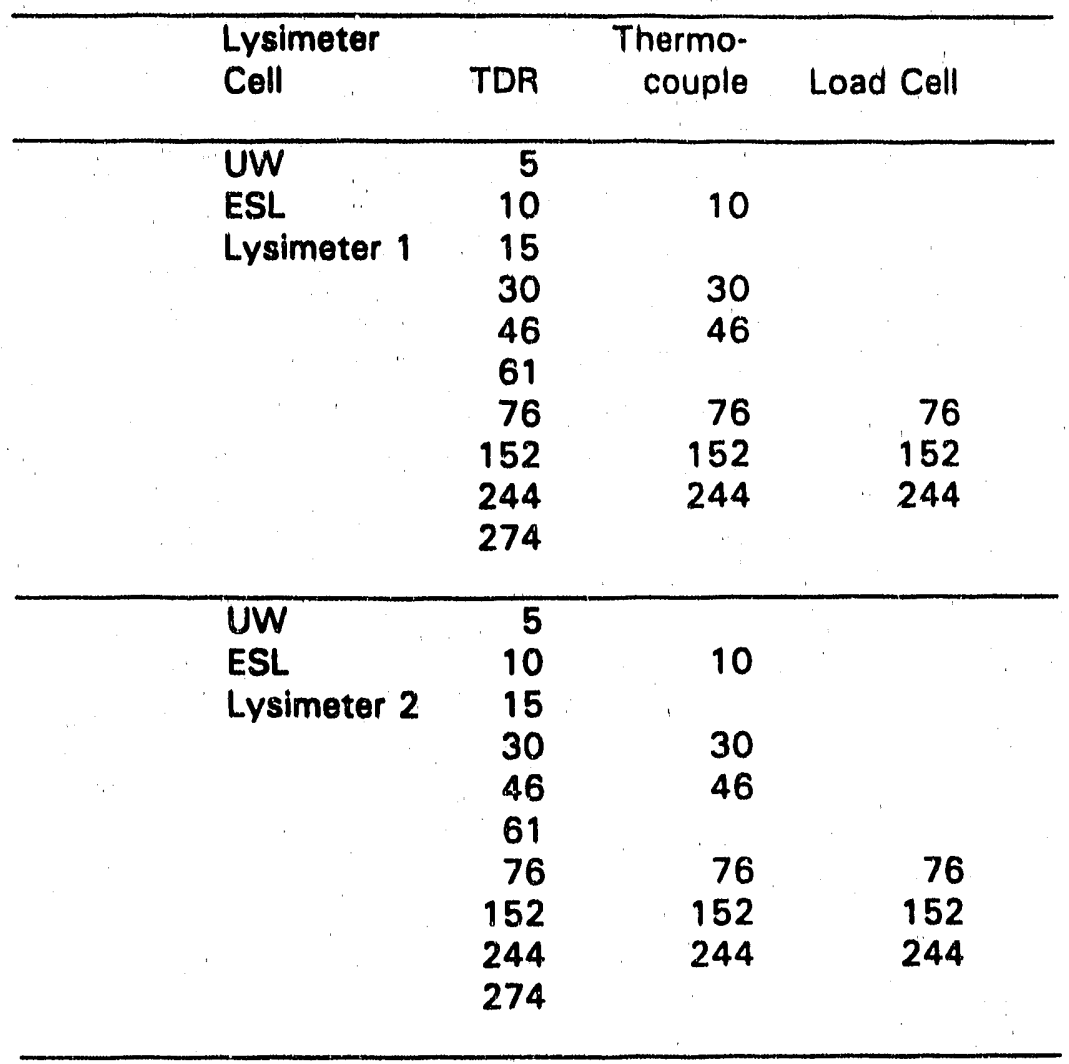

Volumetric water content was monitored by two methods, Time Domain Reflectometry (TDR) and neutron moderation. The primary method for obtaining water content measurements is by TDR. TDR is a relatively new technique for measuring in situ water content that is accurate and can provide measurements with an extremely high degree of vertical resolution. TDR measures water content through a correlation between the measured apparent dielectric constant of the soil-water-air medium, an electrical property, and the volumetric water content $\left(\theta_{v}\right)$. Laboratory column tests showed that TDR could accurately $( \pm 2.4 \%)$ measure volumetric water content in the Lurgi processed oil shale up to values approaching $100 \%$ saturation. The data obtained by neutron moderation was used primarily for backup data to the TDR.

Neutron moderation, which is based on the thermalization of fast neutrons by hydrogen, was considered less accurate than the TDR method because of the formation of hydrated mineral species (cementation) upon wetting, curing and rewetting within the profile. Different depths within the 
processed oil shale would be exposed to different amounts of water and varying amounts of hydration could occur. This is the primary reason neutron measurements were used as backup data to data obtained using TDR. Water content data measured by neutron moderation, have been compiled and are available in both hard copy and on computer disc. These data could be obtained by contacting the UW project manager.

Water content data will be utilized to assess changes in volumetric storage of water by depth in the lysimeters (Objective 1.3) and to measure the direction and flux of water by depth (Objective 1.4). These analyses are discussed in detail in section 4.3.4.

Thermocouples were installed to monitor temperature by depth. Automatic data logging systems were used at the RBOSC site and at the ESL to scan and log thermocouple data. Pneumatic load cells were used at the RBOSC site to monitor total horizontal and vertical stress. These instruments were monitored monthly. The load cells installed in the ESL at UW contained an electronic pressure transducer which allowed automatic monitoring by the data logging system. These data were taken daily. Soil water access tubes (suction cup lysimeters) were installed at RBOSC and in the ESL to monitor in situ soil water chemistry (Objective 2.2 and 2.3 ).

\subsubsection{CORING PROGRAM FOR GEOTECHNICAL AND CHEMICAL ANALYSIS}

A coring program was designed to extract cores from cell 1 of the RBOSC Iysimeters. The purpose of this program was to extract "undisturbed" cores from various depths within the lysimeters and conduct identical bench-scale tests to analyze for geotechnical properties and leachate chemistry as were previously described in section 4.2 above. An alternate objective of the coring program was to gravimetrically analyze cores for water content to cross check the water content data obtained by TDR and neutron moderation. A Giddings ${ }^{4}$ soil sampling probe was used with a 5 $\mathrm{cm}$ dia. sampling tube equipped with a $3.6 \mathrm{~cm}$ dia. bit to obtain cores. The $3.6 \mathrm{~cm}$ dia. core size matches the specimen size used for shear strength and leachate chemistry in the bench top

\footnotetext{
"Giddings Machine Co., Inc. Fort Collins, Colorado.
} 
testing program.' Drilling methods included both rotary drilling with a thin-walled sampler designed for sensitive soils and hammering a core into the processed shale.

Efforts to obtain intact cores from the RBOSC lysimeters were undertaken du,ing two visits to the site during July and August 1989. These efforts were not successful. Only highly disturbed materials were recovered by both drilling methods. It is our opinion that the processed shale in the field lysimeters is not cemented sufficiently to obtain intact core samples for strength testing. Studies on potential changes in the physical and constitutive properties of weathered processed shale would have to be conducted on samples that are weathered artificially in the laboratory. These studies have been described with bench scale testing program, section 4.2 .2 .

\subsubsection{LEACHATE CHEMISTRY AND FLUX}

Attempts to obtain in situ water samples using the soil water access (suction cup Iysimeters) at the RBOSC and the ESL lysimeters have been unsuccessful (Objective 2.2 and 2.3). This is because the water content of the processed oil shale in the lysimeters is too dry to extract in situ water from the porous media. To obtain samples with this instrumentation, water within the pores must be held at pore water pressures greater than $-80 \mathrm{kPa}$ (i.e. less than $80 \mathrm{kPa}$ of suction). This constitutes a relatively moist condition in most soils. Sampled pore water would have been analyzed using the same methods as those employed for bench scale leaching tests. Calculation of cumulative chemical flux during leaching of the lysimeters is dependent on obtaining soluble chernistry data from these samples. It is unknown if moisture regimes within the processed oil shale will reach a level in the future to allow in situ pore water samples to be extracted. 


\subsubsection{HYDROLOGIC ANAL.YSES}

Measurements of volumetric water content $\left(\theta_{v}\right)$ were taken at the location of each TDR probe (see tables 4.3.1.1 and 4.3.1.2) for each sampling date (Objectives 1.3 and 1.4). Plots have been generated of $\theta_{v}$ versus depth below the ground surface for each sampling date, for each replicative set of instrumentation in each of the 5 lysimeters. As an example, Figure 4.3.4.1 is a soil moisture profile for one set of TDR instrumentation in cell 1 at the RBOSC field site taken May 11, 1988. A complete set of raw data and soil moisture profiles for each sampling date is on file and can be obtained by contacting the UW project manager.

Soil moisture profiles were used to estimate two hydrologic parameters of the spent shale embankments: 1) volumetric flux of water, and 2) hydraulic gradient. These data were used to estimate the hydraulic conductivity, as follows:

According to Darcy's Law, which governs the flow of water through porous media,

$$
q=k \times i
$$

where $q=$ volumetric flow rate or flux $\left(\mathrm{cm}^{3} / \mathrm{cm}^{2} / \mathrm{sec}\right), k=$ hydraulic conductivity $(\mathrm{cm} / \mathrm{sec})$, and $i=$ the hydraulic gradient. To illustrate the numerical analysis, Table 4.3.4.1 presents the calculation of $q_{1} i$, and $k$ for one set of data in cell 1 at RBOSC, for the depth interval between $76 \mathrm{~cm}$ and $168 \mathrm{~cm}$ and for the time period between July 23 and August 12 of 1988 . Figure 4.3.4.2 shows the moisture profiles for the two sampling dates. The shaded area between the curves represents the change in water content (change in storage) for the time period between the two readings. The area was determined by planimetry to be $1.03 \mathrm{~cm}^{3} / \mathrm{cm}^{2}$. The change in volumetric water content $(\Delta V)$ is divided by the time interval ( $\Delta t=20$ days) to yield the average volumetric flux $(q)$ between these depths:

$$
\begin{aligned}
& q=\Delta V / \Delta t \\
& q=1.03 \mathrm{~cm}+20 \text { days }=5.2 \times 10^{-2} \mathrm{~cm} / \text { day. }
\end{aligned}
$$

The hydraulic gradient (i) was estimated for the soil moisture profile using the soil moisture 


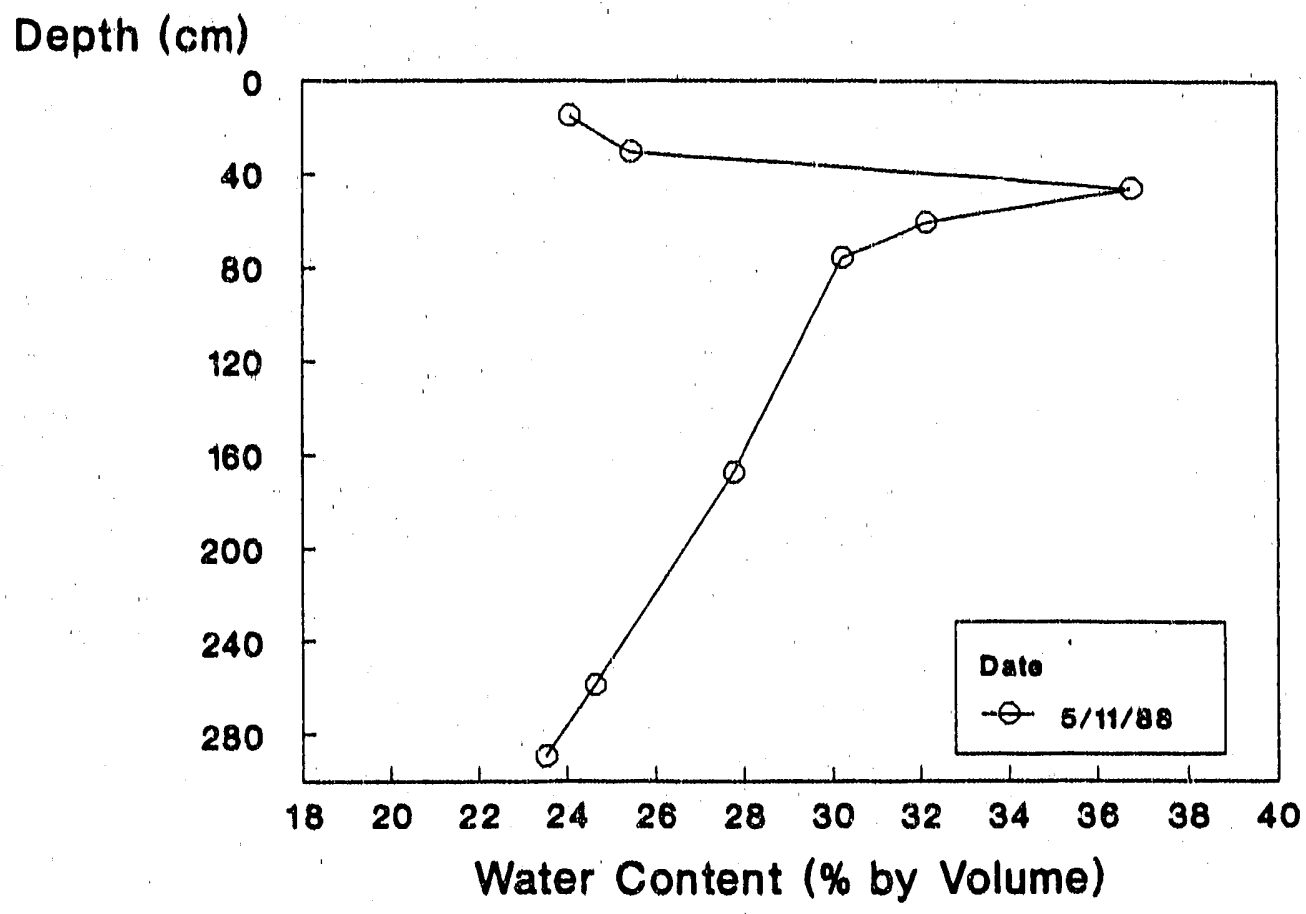

Figure 4.3.4.1 Moisture profile for cell 1 at the RBOSC field site on May 11, 1988. 
Tahle 4.3.4.1 Sample calculations for hydraulic flux, gradient, and conductivity. Pt. A: $z=76 \mathrm{~cm} \quad \Delta V=1.03 \mathrm{~cm}$ (by planimetry)

Pt. B: $z=168 \mathrm{~cm} \quad q=1.03 \mathrm{~cm}+20$ days $=5.2 \times 10^{.2} \mathrm{~cm} /$ day

$\Delta z=92 \mathrm{im}$

\begin{tabular}{|c|c|c|c|c|}
\hline & \multicolumn{2}{|c|}{$7 / 23 / 88$} & \multicolumn{2}{|c|}{$8 / 12 / 88$} \\
\hline & Pt. A & Pt. B & Pt. A & Pt. B \\
\hline $\begin{array}{l}\theta_{v}(\%) \\
\text { Soil Suction }(\mathrm{kPa}) \\
\text { Pressure Head }(\mathrm{cm}) \\
\text { Total Head }\end{array}$ & $\begin{array}{c}30.0 \\
.37 .0 \\
-370.0 \\
-279.0\end{array}$ & $\begin{array}{c}28.7 \\
-43.9 \\
-439.0 \\
-439.0\end{array}$ & $\begin{array}{c}28.5 \\
-45.0 \\
-450.0 \\
-359.0\end{array}$ & $\begin{array}{c}28.0 \\
-47.2 \\
-472.0 \\
-472.0\end{array}$ \\
\hline \multicolumn{5}{|c|}{$\begin{array}{l}\text { Gradient } i_{1}=(-279-.439) / 92=1.73 \quad i_{2}=(-359--472) / 92=1.23 \\
\text { Average Gradient }=1.48\end{array}$} \\
\hline \multicolumn{5}{|c|}{ Hydraulic Conductivity: $\begin{aligned} k & =5.2 \times 10^{.2} / 1.48=3.5 \times 10^{.2} \mathrm{crn} / \mathrm{day} \\
k & =4.1 \times 10^{-7} \mathrm{~cm} / \mathrm{sec}\end{aligned}$} \\
\hline
\end{tabular}

characteristic curvess (Figures 5.1.2.6.1 and 5.1.2.6.2; presented later). For each sampling date, the water contents at depths $A$ and $B$ were used to estimate soil suctions from the soil moisture characteristic curve. For example, $\theta_{v}$ at depth $A(z=76 \mathrm{~cm})$ on July 23 was $30 \%$. From the soil moisture characteristic curve, the corresponding soil suction is approximately 0.37 bar ( 37.0 $\mathrm{kPa}$ or $\left.0.37 \mathrm{~kg} / \mathrm{cm}^{2}\right)$. Soil suction is then converted to pressure head $\left(H_{p}\right)$ by

$$
\begin{aligned}
& H_{p}=u+V_{w} \\
& H_{p}=-0.37 \mathrm{~kg} / \mathrm{cm}^{2}+1 \mathrm{~g} / \mathrm{cm}^{3}=-370 \mathrm{~cm}
\end{aligned}
$$

where $u=$ soil suction, and $\gamma_{w}=$ unit weight of water. The negative sign indicates negative pore water pressure or soil suction. Pressure head at depth $B(z=76 \mathrm{~cm})$ for the same date is found to be $-439 \mathrm{~cm}$. The total head $\left(H_{1}\right)$ at each point is the sum of the pressure head and elevation head. If depth $B$ is taken as an elevational reference datum, the elevation head at depth $A$ is $91 \mathrm{~cm}$ and the elevation head at depth $B$ is $O \mathrm{~cm} . H_{1}$ for each depth $A$ and $B$ are then given by:

$$
\begin{aligned}
& H_{1}=H_{0}+H_{p} \\
& H_{t, A}=91-370=-279 \mathrm{~cm}
\end{aligned}
$$




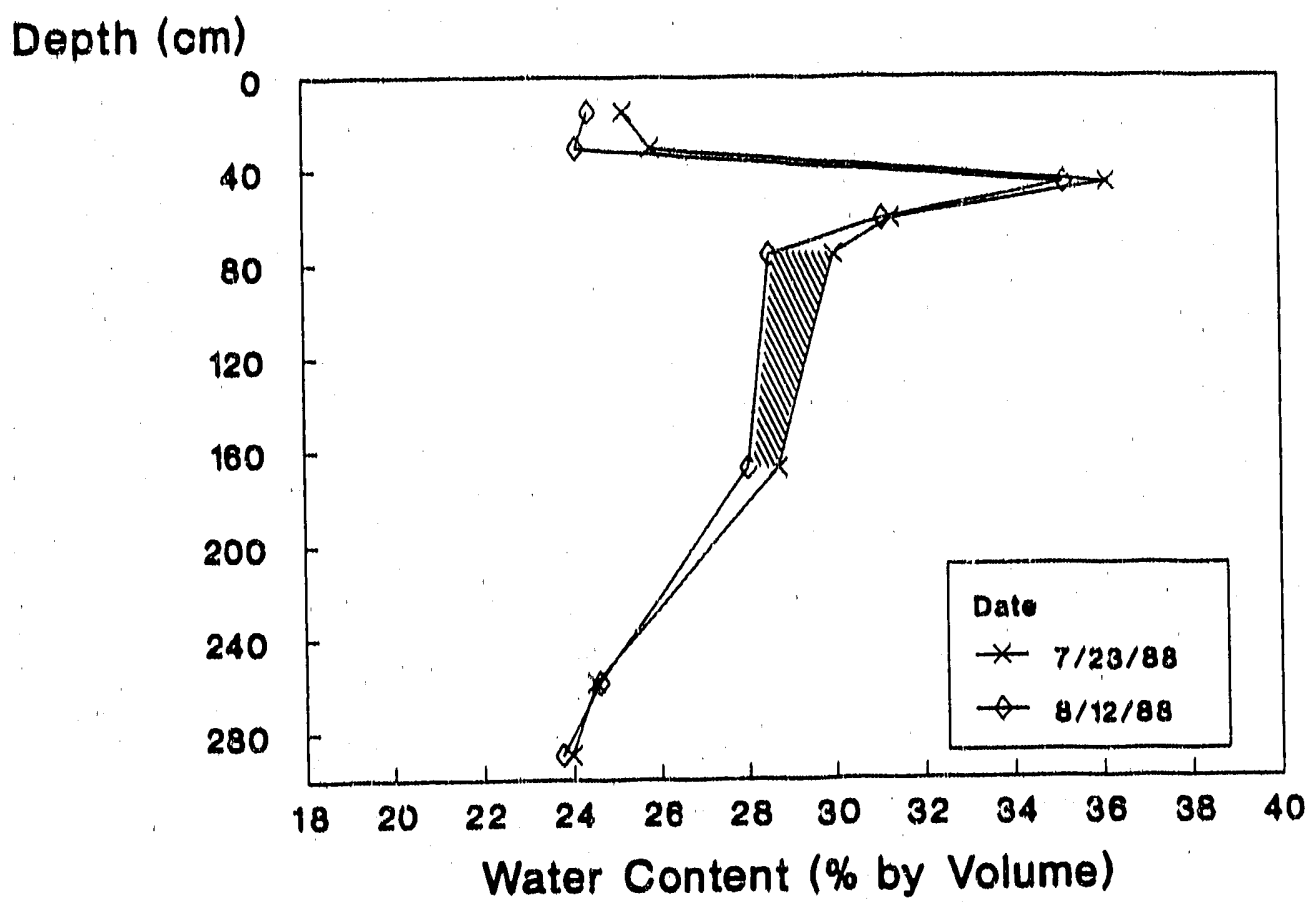

Figure 4.3.4.2 Moisture profiles for two sampling dates July 23, and August 12, 1988. The shaded area between the curves represents the change in water content between the depths of 80 and $160 \mathrm{~cm}$ for the time period. 


$$
H_{1, g}=0.439=-439 \mathrm{~cm}
$$

where $H_{\text {. }}$ is the elevational head. The hydraulic gradient (i) over this depth interval then is computed as:

$$
\begin{aligned}
& I=\Delta H+I \\
& I=(-279--439)+(168-76)=1.73
\end{aligned}
$$

where $\Delta H$ represents the difference in total head between depths $A$ and $B$ and $1=$ vertical distance between $A$ and $B$. The pressure heads and resulting gradient for the August 12 sampling date are computed similarly and the gradient is found to be 1.23 . The average gradient over the $\mathbf{2 0}$ day time interval is estimated as the average of the beginning and ending gradients.

$$
l_{\text {avo }}=(1.73+1.23)+2=1.48
$$

From Darcy's Law, the hydraulic conductivity is then computed as:

$$
\begin{aligned}
& k=q / i \\
& k=5.2 \times 10^{-2} \mathrm{~cm} / \text { day }+1.48=3.5 \times 10^{.2} \mathrm{~cm} / \text { day } \\
& k=4.1 \times 10^{.7} \mathrm{~cm} / \mathrm{sec}
\end{aligned}
$$

\subsubsection{STRESS TESTING}

A knowledge of the in situ state of stress is necessary for proper design and construction of oil shale solid waste embankments for two reasons. First, the stress history of the embankment, covering the initial through final stress conditions, is needed to evaluate the overall engineering performance of a constructed embankment. This includes behavior such as slope stability, settlement, and the construction of future facilities on top of a completed embankment. Second, nearly all engineering properties of spent shale are a function of the soll stresses, either directly or indirectly. This includes shear strength, stress-strain properties, compressibility, and hydraulic conductivity. 
As indicated in section 4.3.1 load cells were installed in the lysimeters at ROOSOS and in the ESL to monitor total horizontal and vertical stress. Analysis of these data were not complete at the time of this report. These data will be discussed and summarized in the final project report.

\subsection{COMPUTER MODELING PROGRAM}

\subsubsection{HYDROLOGIC MODELING}

An extensive literature review was done on existing computer model(s)/code(s) avallable for use in the analysis of water and solute movement in oil shale solid waste material disposal (Objective 4.1). A summary of this review is given below and results in section 5.3 .1 with details presented in a topical report being currently prepared as a separate document under this project.

A literature review was initiated as the first phase in the evaluation and validation of geohydrochemical models capable of predicting the migration and fate of leachate in processed oil shale solid waste material disposed of in large embankments. One part of the evaluation was to select already existing codes which are capable of predicting the migration of leachate through soils in the unsaturated as well as saturated zones.

The evaluation of computer codes was basid upon (1) development of a selection criteria and (2) selection of codes through identification of fundamental physical and geochemical processes which could possibly handle the complex processes associated with an oil shale solid waste disposal pile.

A two - level selection process was developed to screen the list of available codes and reduce the evaluation of the codes to a selected number of manageable characteristics, and to select a set of codes representative of tests that could be used to predict leachate composition and migration resulting from this list. The codes were classified according to the processes they model (hydrological and geochemical processes). 


\subsubsection{GEOTECHNICAL MODELING}

Objective 5.0 and its associated subobjectives 5.1 and 5.2 were added to the program work plan during the early stages of the research, but after the cooperative agreement was in place. After conducting preliminary assessments of available computer programs, it is the opinion of the principal investigators that this objective is beyond the scope of work for this project. It is felt that the remaining work effort and financial resources will be more productive if they are highly focused on evaluating the experimental results. 


\subsection{RESULTS AND DISCUSSION}

\subsection{BENCH SCALE RESEARCH PROGRAM}

\subsubsection{LEACHATE CHEMISTRY}

Figures 5.1.1.1 through 5.1.1.6. show mean results from column leaching tests for sodium, chloride, sulfate, magnesium, calcium and total alkalinity respectively. Most of the constituents measured showed typical S-shaped breakthrough curves and leaching behavior. The concentration of the constituents being measured reduces eventually becoming asymptotic. Effects on leaching behavior caused by preparing the specimens at 15 and 20 percent viater contents are not apparent for aily of the constituents except for calcium (Figure 5.1.1.5). The leaching of calcium becomes asymptotic approximately $100 \mathrm{mg} / \mathrm{l} \mathrm{higher}$ when the processid oil shale was prepared at 15 percent than at 20 percent. This result may indicate the importance of calcium as an a constituent in secondary mineral formation during hydration and cementation of the processed oil shale. Cementation reactions involving calcium may have been incomplete when the processed oil shale was hydrated with 15 percent water. As leaching off the specimens was initiated, cementation reactions may have also initiated causing calcium to bo tied up in the formation of secondary minerals. A more detailed oiscussion of cementation is presented in section 5.1.3.

Final concentrations of sodium and sulfate (Figure 5.1.1.1 and 5.1.1.3 respectfully) leveled off at approximately $1000 \mathrm{mg} / \mathrm{l}$, an order of magnitude higher than the other constituents measured. It is not known what chemical species or conditions buffer the release of sodium and sulfate at these relatively high levels. 


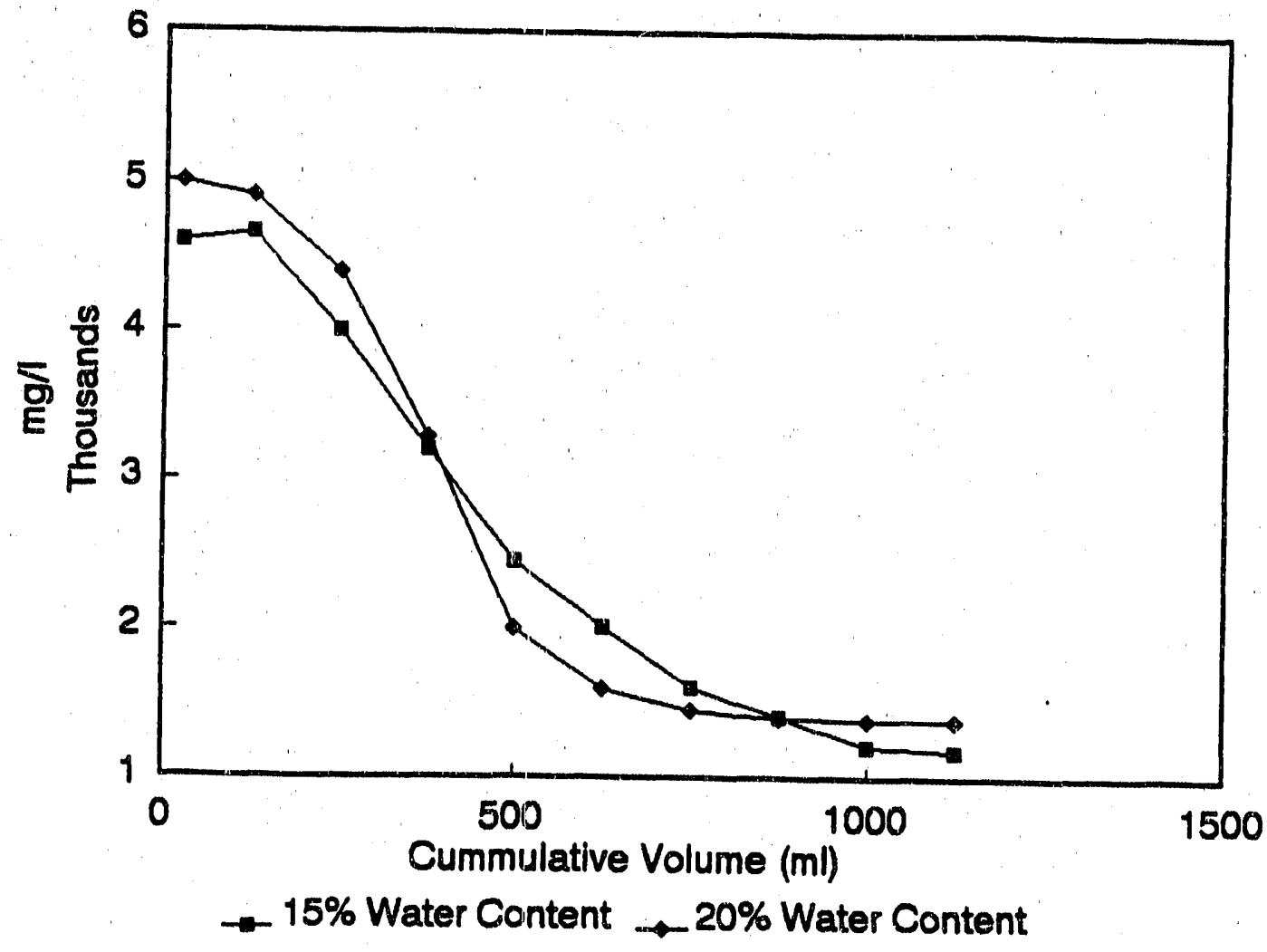

Figure 5.1.1.1 Sodium $\left(\mathrm{Na}^{+}\right)$concentration by cumulative volume of leachate for processed oil shale cores prepared at 15 and 20 percent water content (w/w). 


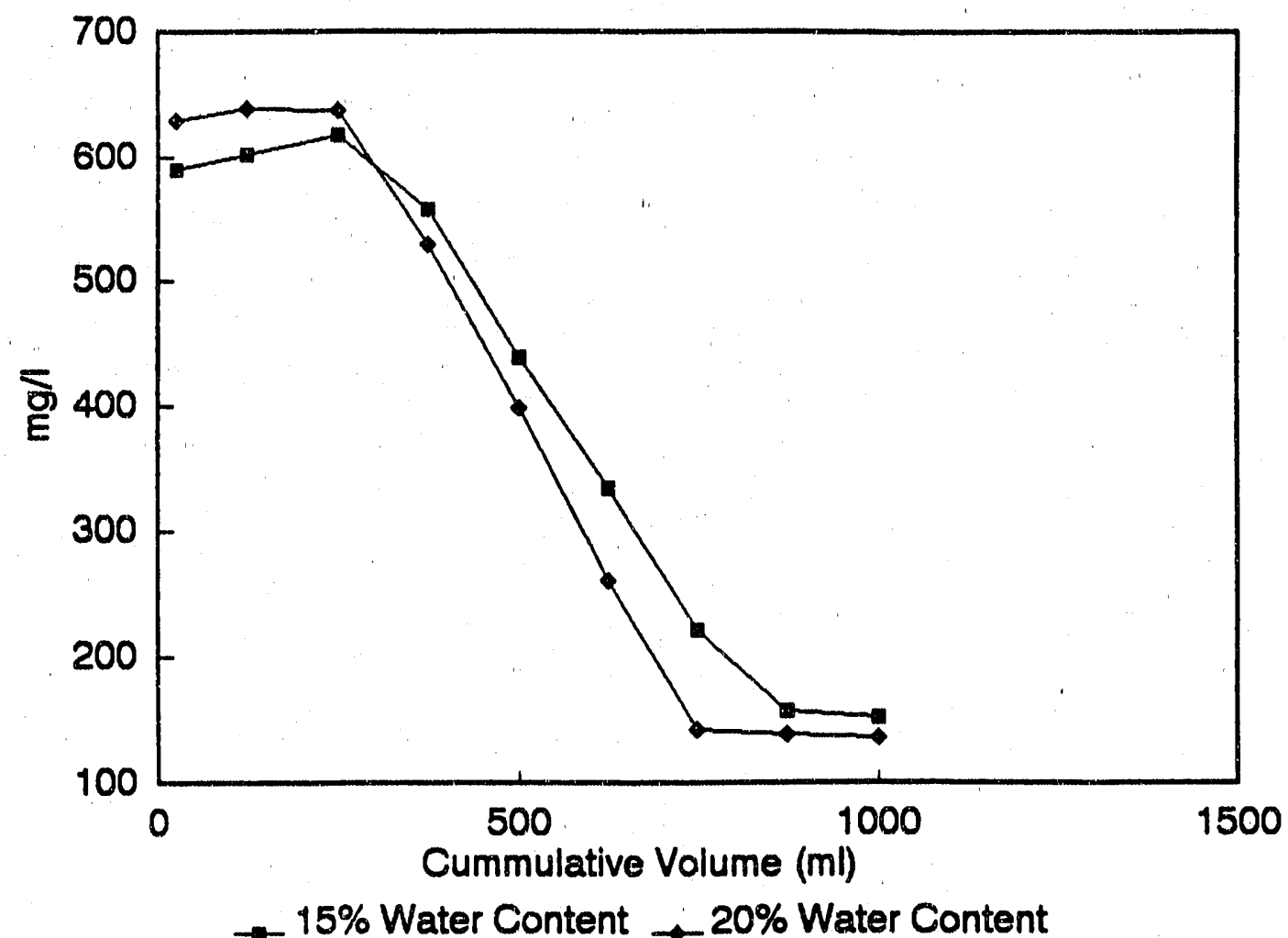

Figure 5.1.1.2 Chloride ( $\left.\mathrm{Cl}^{-1}\right)$ concentration by cumulative volume of leachate for processed Oil shale cores prepared at 15 and 20 percent water content $(w / w)$. 


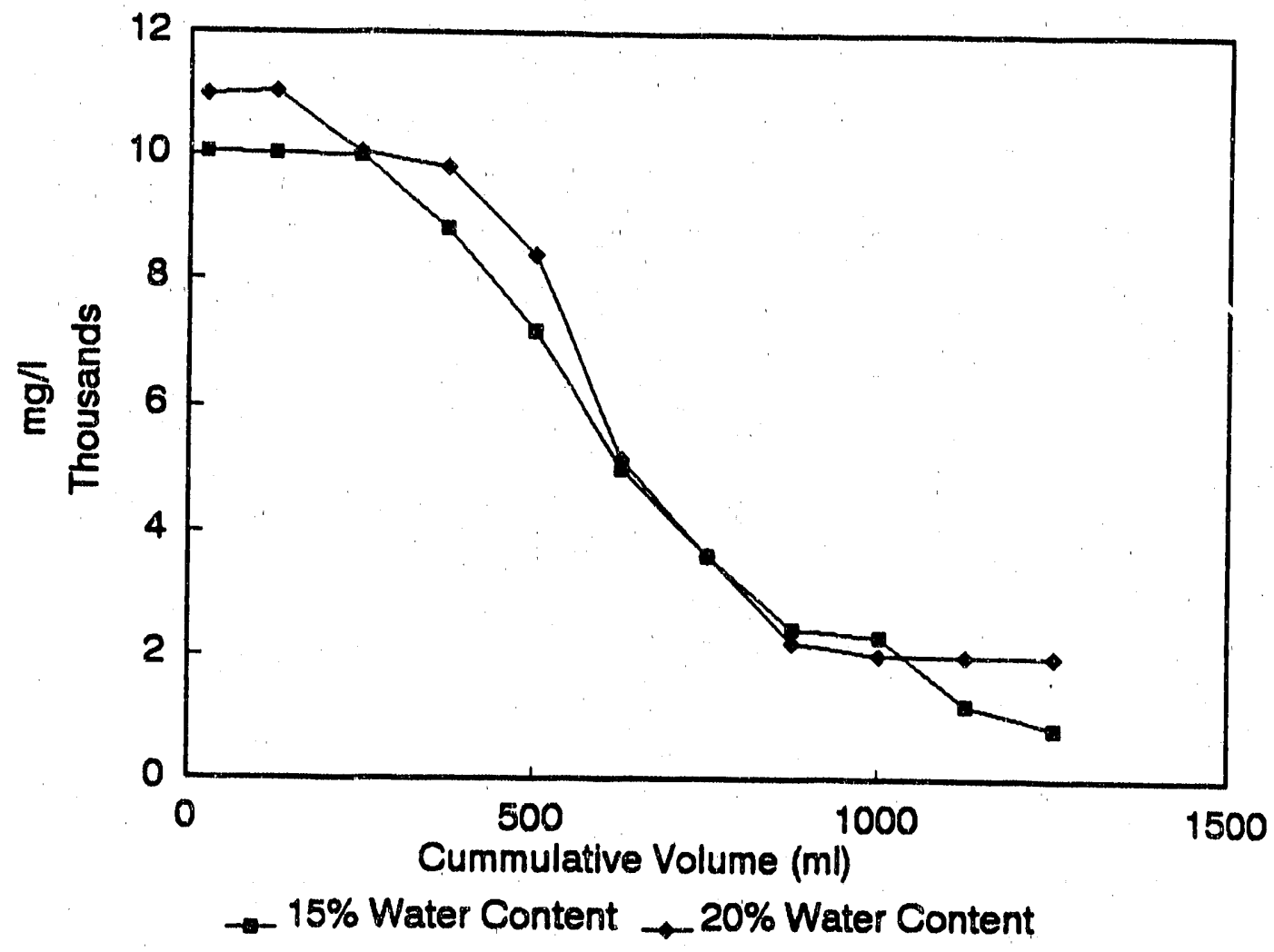

Figure 5.1.1.3 Sulfate $\left(\mathrm{SO}_{4}^{-2}\right)$ concentration by cumulative volume of leachate for processed oil shale cores prepared at 15 and 20 percent water content (w/w). 


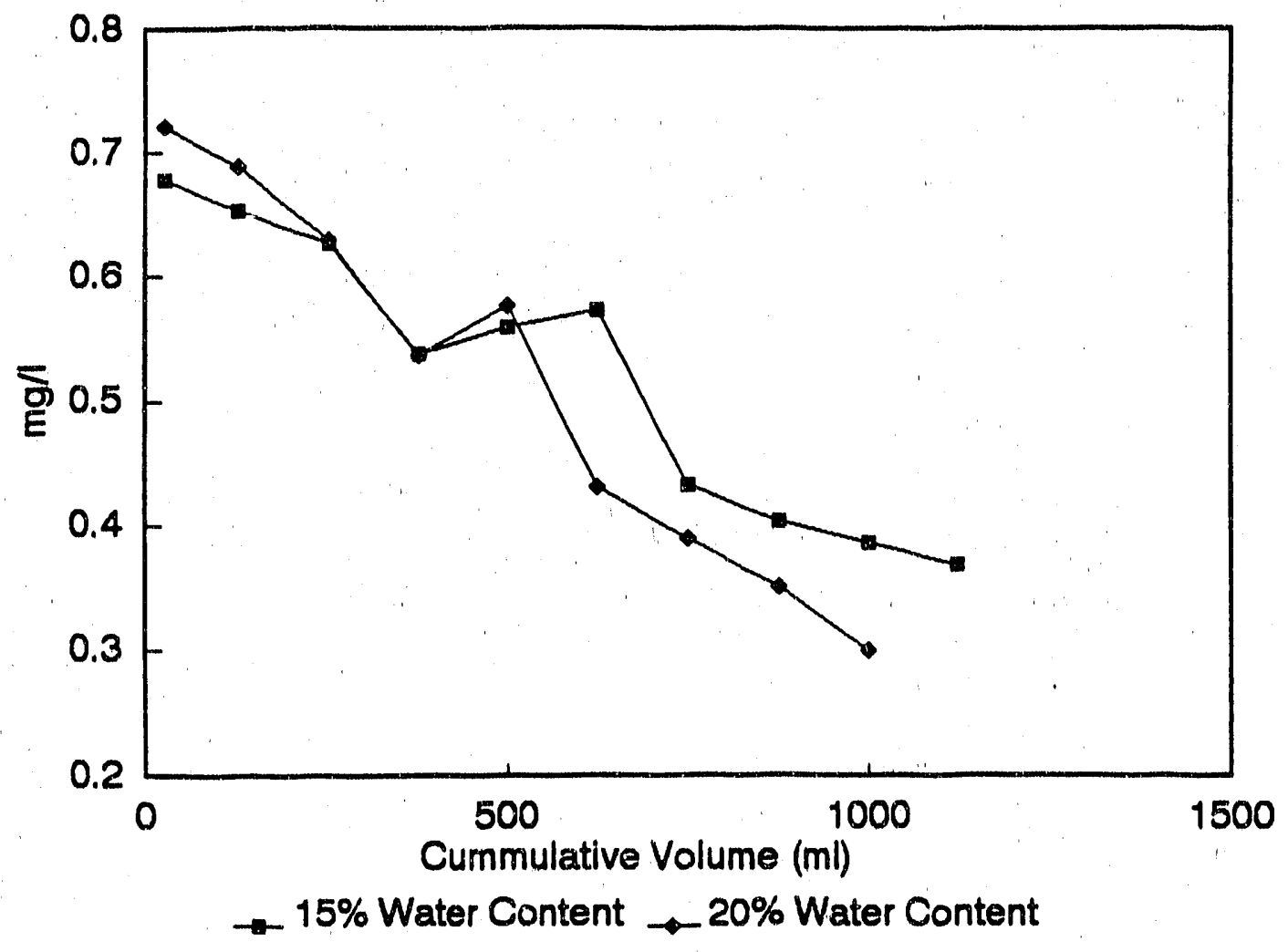

Figure 5.1.1.4 Magnesium $\left(\mathrm{Mg}^{+2}\right)$ concentration by cumulative volume of leachate for processed oil shale cores prepared at 15 and 20 percent water content $(w / w)$. 


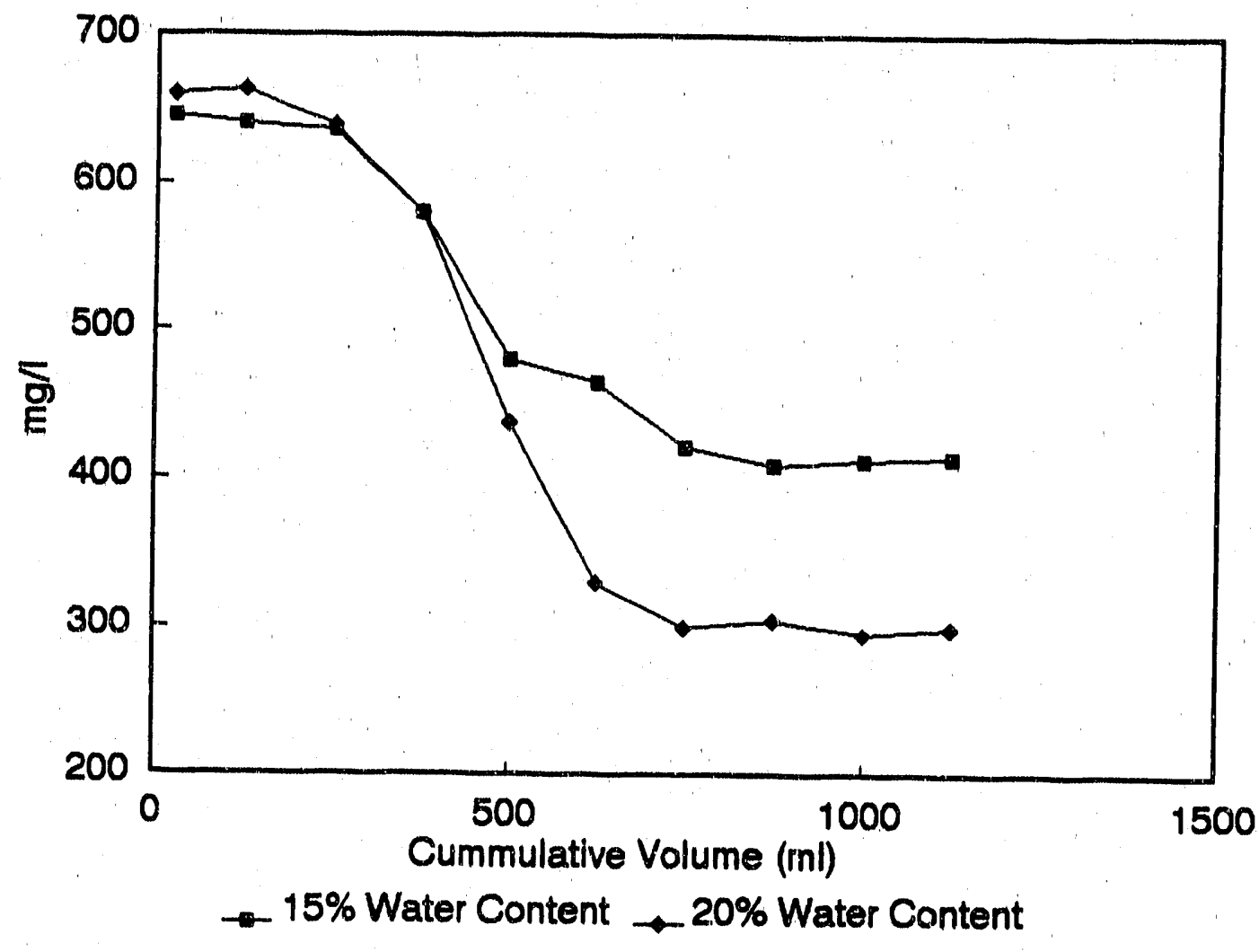

Figure 5.1.1.5 Calcium $\left(\mathrm{Ca}^{2+}\right)$ concentration by cumulative volume of leachate for processed Oil shale cores prepared at 15 and 20 percent water content $(w / w)$. 


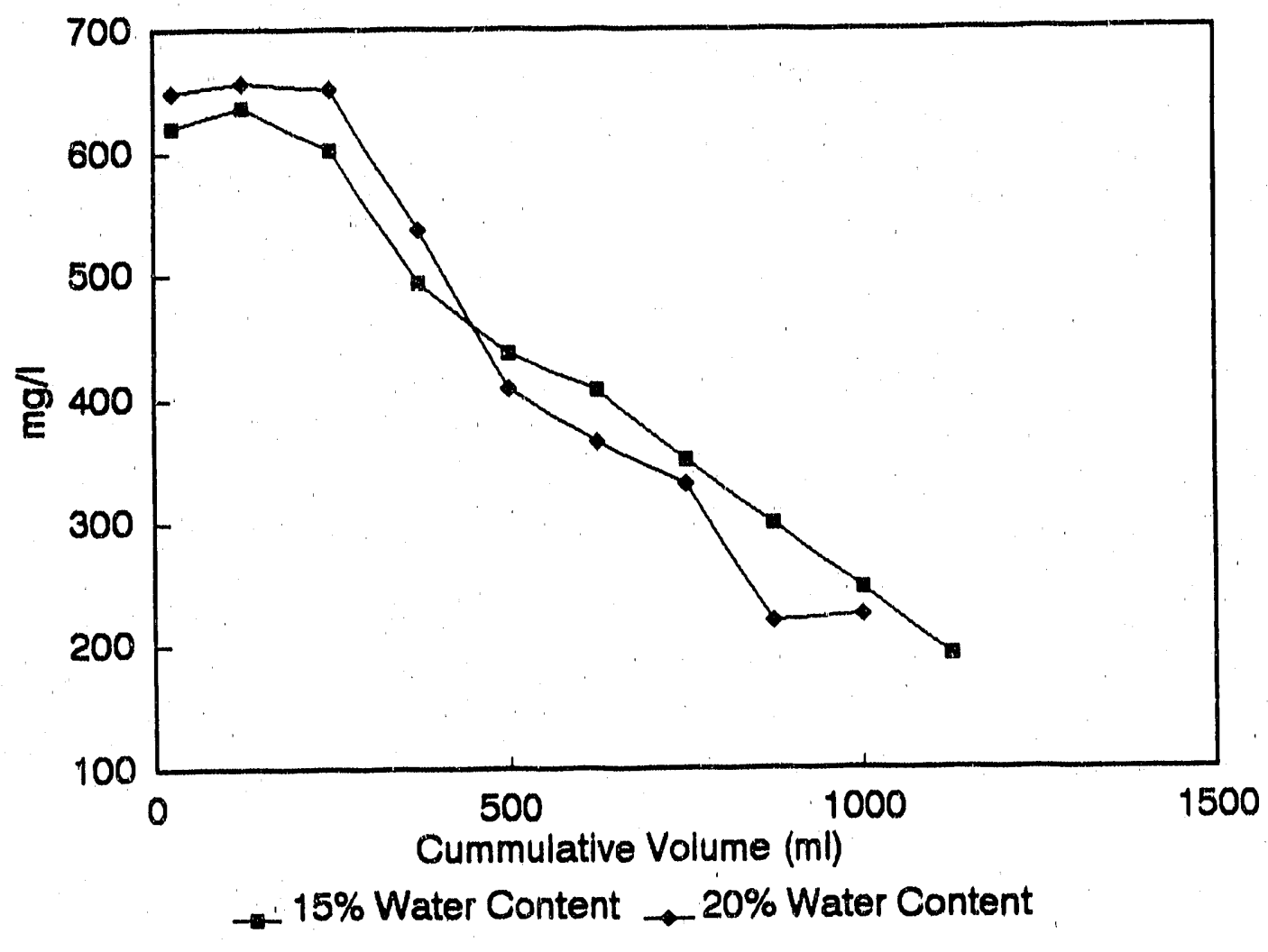

Figure 5.1.1.6 Total alkalinity by cumulative volume of leachate for processed oil shale cores prepared at 15 and 20 percent water content $(w / w)$. 


\subsubsection{GEOTECHNICAL AND HYDROLOGIC PROPERTIES}

\subsubsection{Index properties}

The coefficients of uniformity and curvature, Atterberg limits, and soil classification are summarized in Table 5.1.2.1.1. For the 26 samples of surge bin solids, the mean coefficient of uniformity is 15.5 with a standard deviation of 8.3 , yielding a coefficient of variation of 53.6 percent. The mean coefficient of curvature is 1.8 with a standard deviation of 1.1 and a coefficient of variation of 65.3 percent. Figure 5.1.2.1.1 presents the grain size distribution curves for the surge bin solids. As illustrated by the curves and the coefficients of variation for $c_{u}$ and $c_{c}$ the grain size characteristics of the surge bin solids show a relatively high degree of variability.

The mean liquid limit for the surge bin solids is 33.2 with a standard deviation of 3.4 and a coefficient of variation of 10.3 percent. The mean plastic limit is 34.7 with a standard deviation of 3.8 and a coefficient of variation of 10.9 percent. Within the limit of experimental error, the liquid and plastic linits are equal and, therefore, the processed shale is nonplastic (PI $=0)$. The 26 samples o' surge bin solids are classified as given in Table 5.1.2.1.1 and illustrated graphically in Figure 5.1.2.1.2. Even though the grain size characteristics show a high degree of variability, all of the samples fall into three categories: SP, poorly-graded sand with little or no fines; SM, silty sand; or SW, well-graded sand with little or no fines (ASTM 1985). Nine samples have a dual classification of SW-SM and three are dual-classified as SP-SM. The flue dust, sample 27 , is classified as ML, silt with sand. The grain size distribution curve of the flue dust (Figure 5.1.2.1.1) shows that it is finer grained than the surge bin solids. The material used for all of the remaining tests consisted of 10 percent flue dust and 90 percent surge bin solids, to represent expected production conditions for Lurgi-processed oil shale. The surge bin 
sollds portion was an equal mix of samples 24 and 25 , which has a liquid limit of 34.5, a plastio limit of 35, and is classified as SM. This material was chosen as representative of the average

Table 5.1.2.1.1 Index properties of processed oil shale.

\begin{tabular}{|c|c|c|c|c|c|c|}
\hline Sample & $c_{u}$ & $c_{0}$ & $P L^{\prime}$ & $\mathrm{LI.}^{2}$ & $\left.P\right|^{3}$ & USCS $^{4}$ \\
\hline $\begin{array}{r}1 \\
2 \\
3 \\
4 \\
5 \\
6 \\
7 \\
8 \\
9 \\
10 \\
11 \\
12 \\
13 \\
14 \\
15 \\
16 \\
17 \\
18 \\
19 \\
20 \\
21 \\
22 \\
23 \\
24 \\
25 \\
26 \\
27^{5} \\
28^{6}\end{array}$ & $\begin{array}{r}19.23 \\
12.00 \\
11.25 \\
14.52 \\
24.00 \\
9.44 \\
8.84 \\
10.00 \\
5.56 \\
6.92 \\
9.33 \\
10.38 \\
15.00 \\
6.67 \\
16.84 \\
25.00 \\
17.65 \\
22.39 \\
15.00 \\
36.25 \\
5.91 \\
12.50 \\
17.53 \\
9.23 \\
33.33 \\
27.14 \\
2.14 \\
14.17\end{array}$ & $\begin{array}{l}0.49 \\
1.08 \\
0.87 \\
0.95 \\
1.50 \\
2.65 \\
0.61 \\
1.60 \\
1.74 \\
2.59 \\
2.68 \\
2.05 \\
0.54 \\
2.06 \\
1.19 \\
2.96 \\
2.64 \\
2.59 \\
5.95 \\
2.11 \\
1.26 \\
1.00 \\
1.39 \\
1.18 \\
1.08 \\
0.68 \\
0.72 \\
0.95\end{array}$ & $\begin{array}{l}35.3 \\
26.3 \\
25.5 \\
33.8 \\
37.6 \\
35.7 \\
35.0 \\
32.5 \\
34.7 \\
33.6 \\
37.0 \\
29.4 \\
36.7 \\
25.2 \\
31.4 \\
33.8 \\
33.3 \\
35.3 \\
30.0 \\
36.5 \\
33.2 \\
33.3 \\
36.3 \\
32.1 \\
35.0 \\
34.3 \\
39.5 \\
34.6\end{array}$ & $\begin{array}{l}37.0 \\
28.0 \\
26.3 \\
34.0 \\
39.0 \\
38.0 \\
36.1 \\
34.1 \\
37.7 \\
35.3 \\
39.0 \\
30.0 \\
39.0 \\
26.4 \\
32.0 \\
35.0 \\
35.6 \\
36.0 \\
31.0 \\
38.5 \\
33.1 \\
36.0 \\
38.6 \\
34.6 \\
37.7 \\
35.4 \\
41.0 \\
35.5\end{array}$ & $\begin{array}{l}1.7 \\
1.7 \\
0.8 \\
0.2 \\
1.4 \\
2.3 \\
1.1 \\
1.6 \\
3.0 \\
1.7 \\
2.0 \\
0.6 \\
2.3 \\
1.2 \\
0.6 \\
1.2 \\
2.3 \\
0.7 \\
1.0 \\
2.0 \\
0.0 \\
2.7 \\
2.3 \\
2.5 \\
2.2 \\
1.1 \\
0.5 \\
0.0\end{array}$ & $\begin{array}{r}S M \\
S M \\
\text { SP.SM } \\
S M \\
S M \\
S W \\
S M \\
\text { SW-SM } \\
S P \\
S W \\
\text { SW-SM } \\
\text { SW-SM } \\
\text { SM } \\
\text { SW-SM } \\
\text { SW-SM } \\
\text { SW-SM } \\
\text { SW-SM } \\
\text { SM } \\
\text { SP-SM } \\
\text { SM } \\
\text { SP-SM } \\
\text { SW } \\
\text { SW-SM } \\
\text { SW-SM } \\
\text { SM } \\
\text { SM } \\
M L \\
S M\end{array}$ \\
\hline
\end{tabular}

1. PL = plastic limit

2. $L L=$ liquid limit

3. $P I=$ plasticity index $=$ LL-PL

4. USCS = Unified Soil Classification System

5. Sample 27 is flue dust

6. Sample 28 is $90 \%$ surge bin solids and $10 \%$ flue dust 


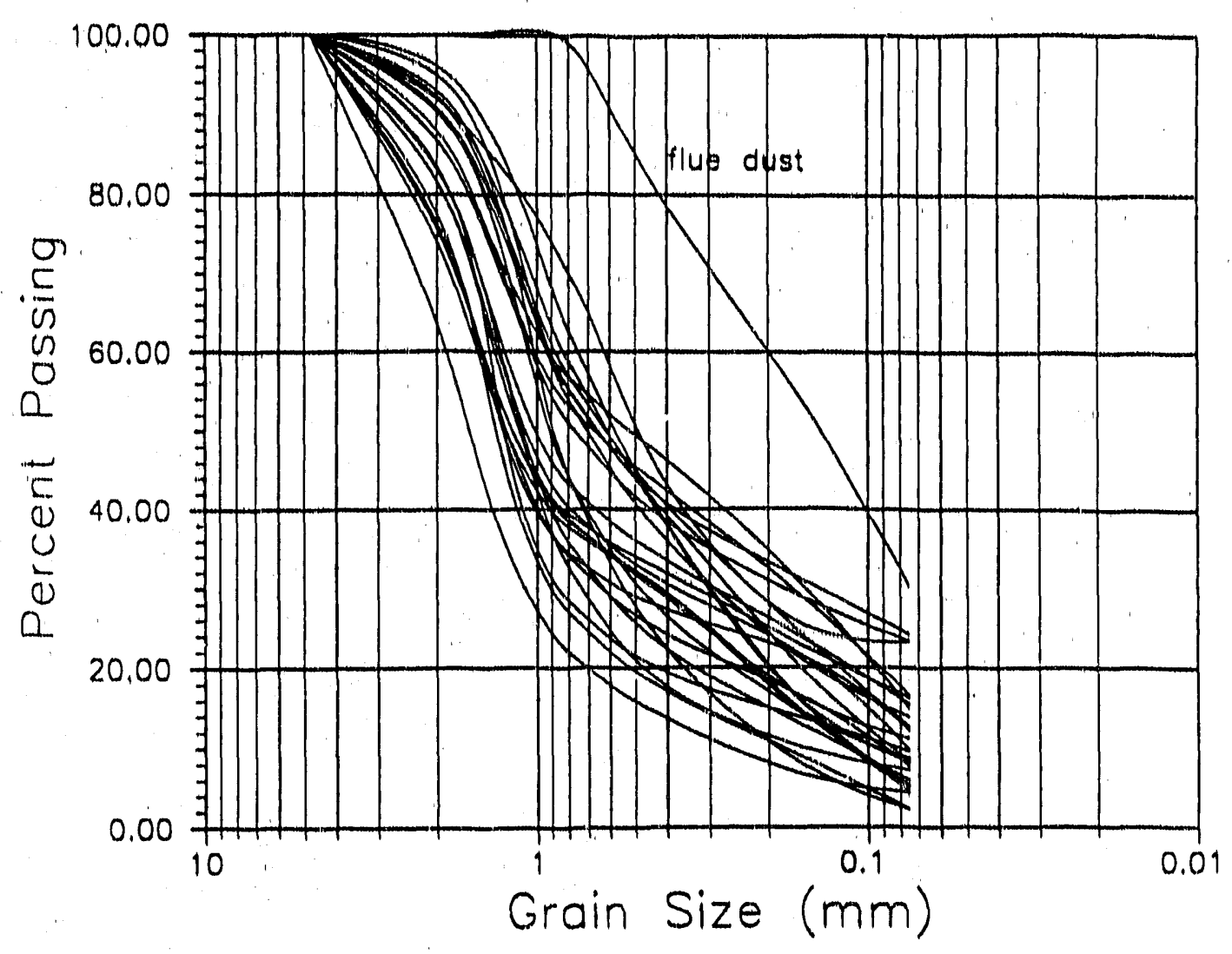

Figure 5.1.2.1.1 Grain size distribution curves. 


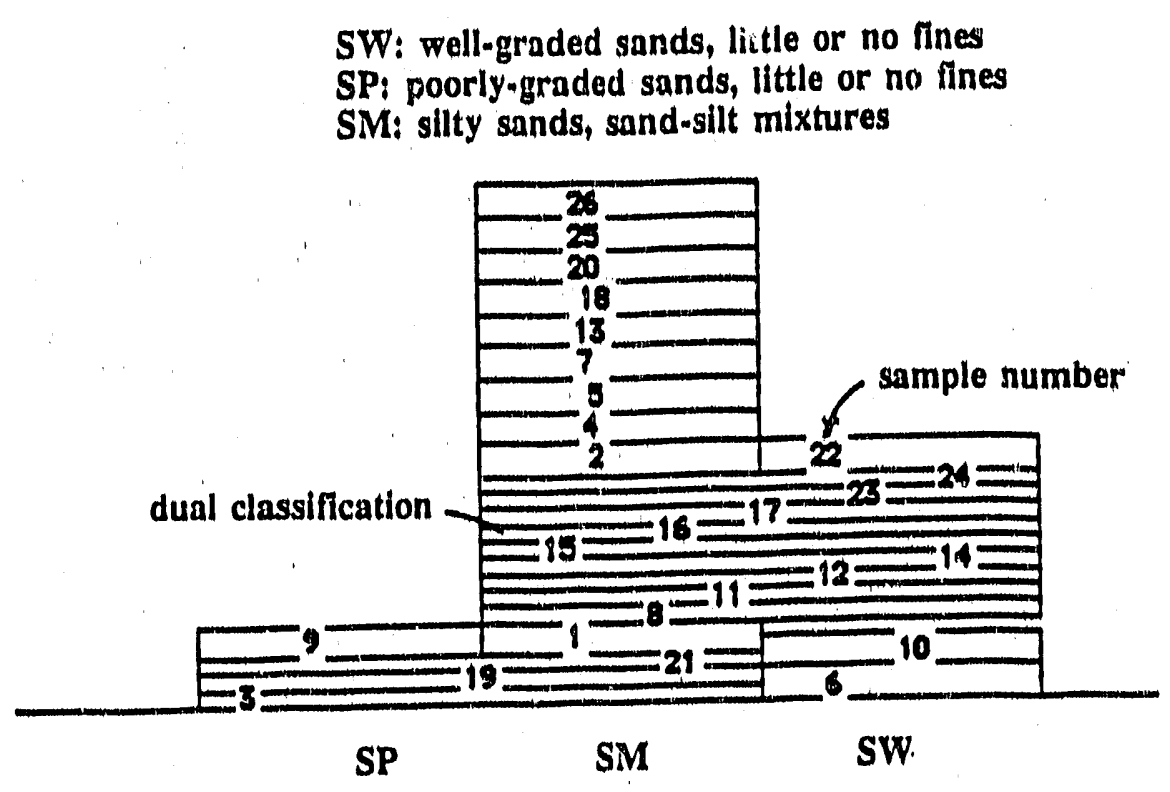

Figure 5.1.2.1.2 Soil classification of surge bin solids. 
properties of the surge bin solids. The $90.10 \mathrm{mlx}$ is classifled as SM, silty sand with no plasticity.

\subsubsection{Moisture-Density Relationships}

Compaction tests were conducted according to ASTM D698-78 to determine the moisturedensity relationships. This test yields the maximum dry density and corresponding water content ("optimum" water content) that are used to specify placement procedures for waste embankments. Three tests were conducted with seven data points for each test. There was. little variation between the three tests and Figure 5.1.2.2.1 shows the curve of dry density versus water content with all 21 data points. The optimum water content is 27 percent and the maximum dry density is $14.7 \mathrm{kN} / \mathrm{m}^{3}$.

\subsubsection{Shear Strength}

Shear strength is the most important soil property required for evaluating the stability of processed shale disposal embankments. Shear strength is not a unique soil parameter and depends upon the loading conditions, water content, effective overburden stress, and stress history of the soil. During the construction phase of an embankment, undrained or short-term loading conditions are critical and the undrained strength is used to evaluate embankment stability. The appropriate strength parameters are the undrained angle of friction $(\phi)$ and undrained cohesion (c) as determined in a consolidated undrained (CU) triaxial test, or the unconfined compressive strength $\left(q_{u}\right)$. Following construction, when the final geometry and overburden stresses have been established, the long-term strength properties are applicable. These include the drained or effective stress angle of friction $\left(\Phi^{\prime}{ }_{D}\right)$, and the drained or effective stress cohesion $\left(c^{\prime}\right)$, as determined from a consolidated drained $(C D)$ triaxial test. 


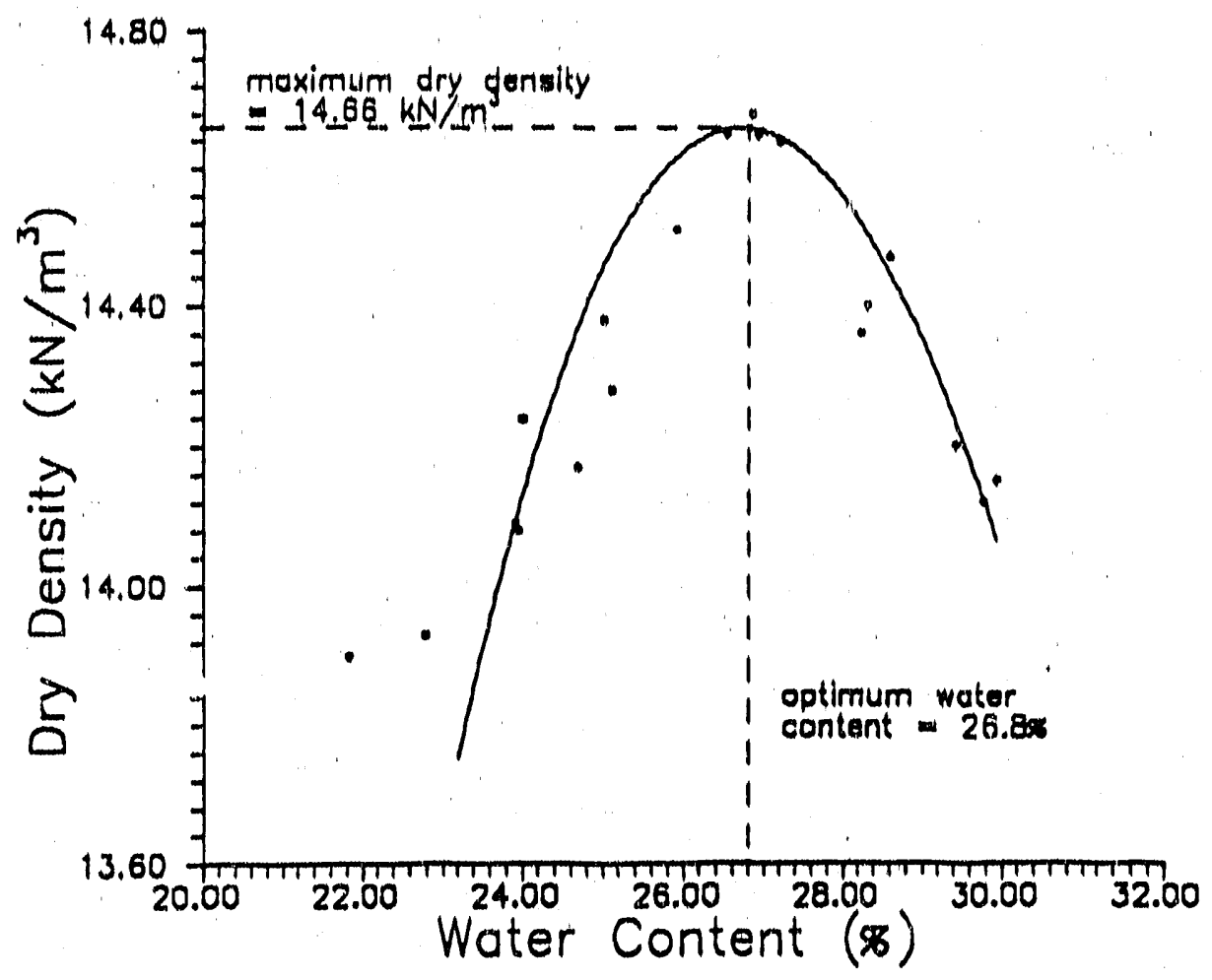

Figure 5.1.2.2.1 Moisture-density relationship for combusted oil shale. 
Consolidated-Drained Triaxial Tests. Twenty-five samples of processed shale were prepared and tested in $C D$ triaxial tests at confining stresses ranging from $48 \mathrm{kN} / \mathrm{m}^{2}$ to 10,345 $\mathrm{kN} / \mathrm{m}^{2}$ (7 psi to $1500 \mathrm{psi}$ ). All samples were prepared at an initial water content of 15 percent and compacted to an average dry density of $14.0 \mathrm{kN} / \mathrm{m}^{3}$, consolidated to cell pressure, and loaded to failure in triaxial compression. Nineteen of the samples were tested in a triaxial cell capable of confining stresses up to $580 \mathrm{kN} / \mathrm{m}^{2}(84 \mathrm{psi})$ and six samples were tested in a high pressure cell capable of applying confining stresses up to $10,345 \mathrm{kN} / \mathrm{m}^{2}$ (1500 psi).

The results of the first nineteen tests with confining stresses up to $580 \mathrm{kN} / \mathrm{m}^{2}$ are plotted in Mohr-Coulomb stress space in Figure 5.1.2.3.1a. The fallure enveiope is approximately linear over this range of confining stresses and is characterized by an effective stress angle of friction of 37.9 degrees and an deffective stress cohesion of $11.9 \mathrm{kN} / \mathrm{m}^{2}$. The fallure envelope for the high confining stress tests is plotted in Figure $5.1 .2 .3 .1 \mathrm{~b}$ and yields a friction angle of 34 degrees and a cohesion of $165.5 \mathrm{kN} / \mathrm{m}^{2}$. This indicates that the failure envelope exhibits curvature at higher confining stresses. Curvature of the failure envelope should be incorporated into stability analyses, by decreasing the friction angle with increasing overburden stress. For example, the friction angle can be decreased by one degree (from its initial value of $\mathbf{3 8}$ degrees) for each $2,000 \mathrm{kn} / \mathrm{m}^{2}$ of overburden stress. The overburden stresses at the bottom of a $300 \mathrm{~m}$ high waste embankment would be in the range of $5,000 \mathrm{kN} / \mathrm{m}^{2}$.

Consolidated-Undrained Triaxial Tests. Fifteen CU triaxial tests were conducted on specimens of processed shale prepared at an initial water content of 15 percent and a dry density of $14.0 \mathrm{kN} / \mathrm{m}^{3}$. Confining stresses ranged from $51.7 \mathrm{kN} / \mathrm{m}^{2}$ to $469 \mathrm{kN} / \mathrm{m}^{2}$. The results are plotted on a Mohr-Coulomb diagram in Figure 5 1.2.3.2 and yield an und ained friction angle of 14.4 degrees and undrained cohesion of $162.0 \mathrm{kN} / \mathrm{m}^{2}$.

Unconfined Compression Tests. The unconfined compression tests were designed to evaluate the effects of cementation on the strength of combusted Lurgi-processed shale. 


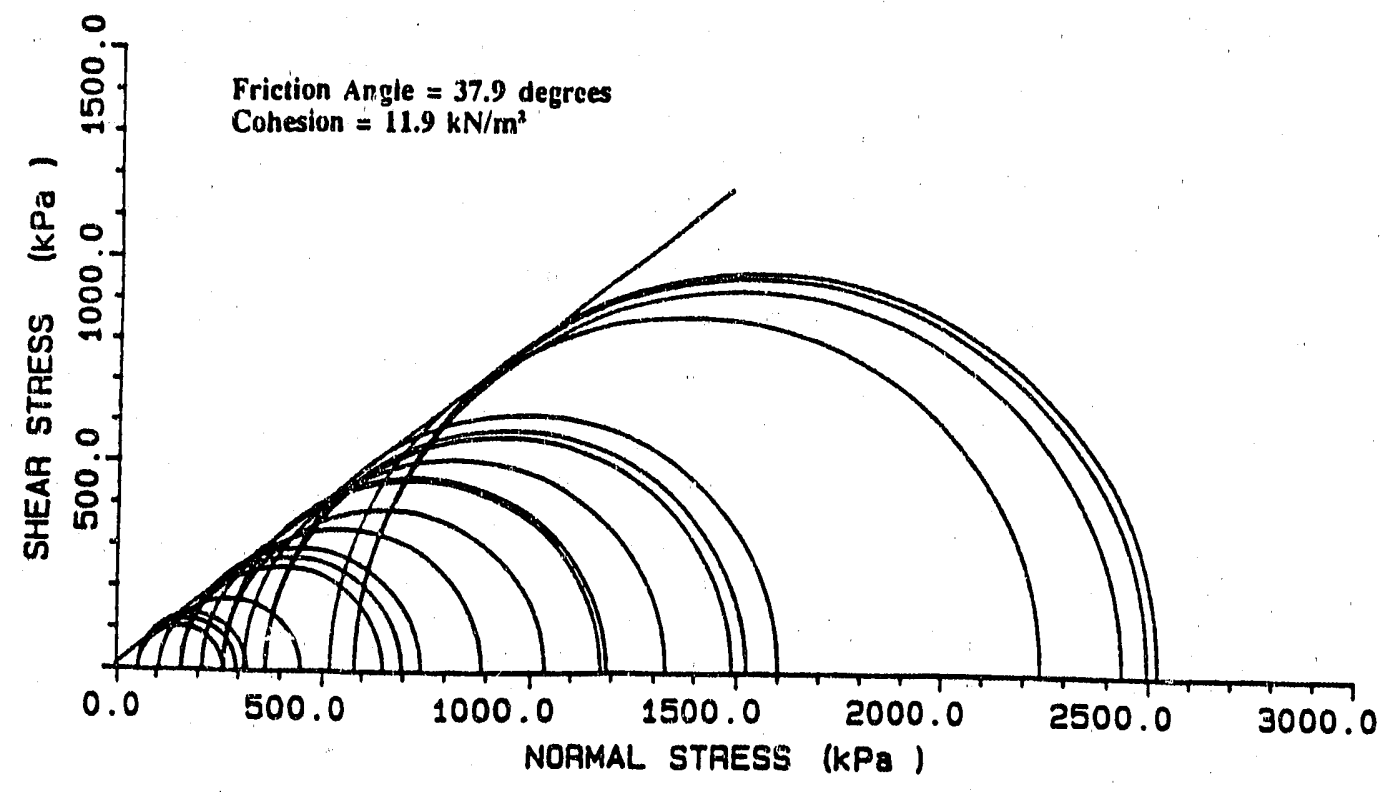

a. Confining stress up to $580 \mathrm{kN} / \mathrm{m}^{2}$

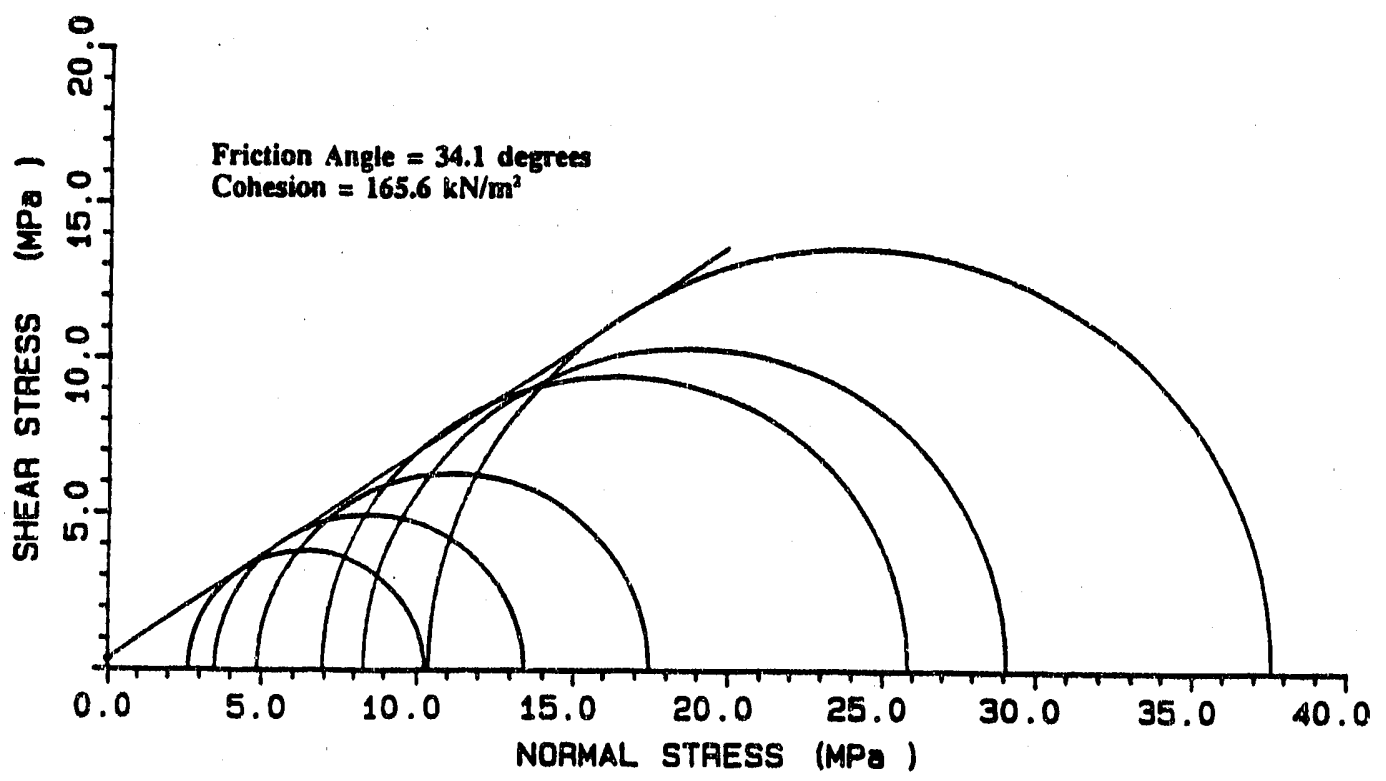

b. Confining stress up to $10.3 \mathrm{MN} / \mathrm{m}^{2}$

Figure 5.1.2.3.1 Mohr-Coulomb failure envelopes from $C D$ triaxial tests. 


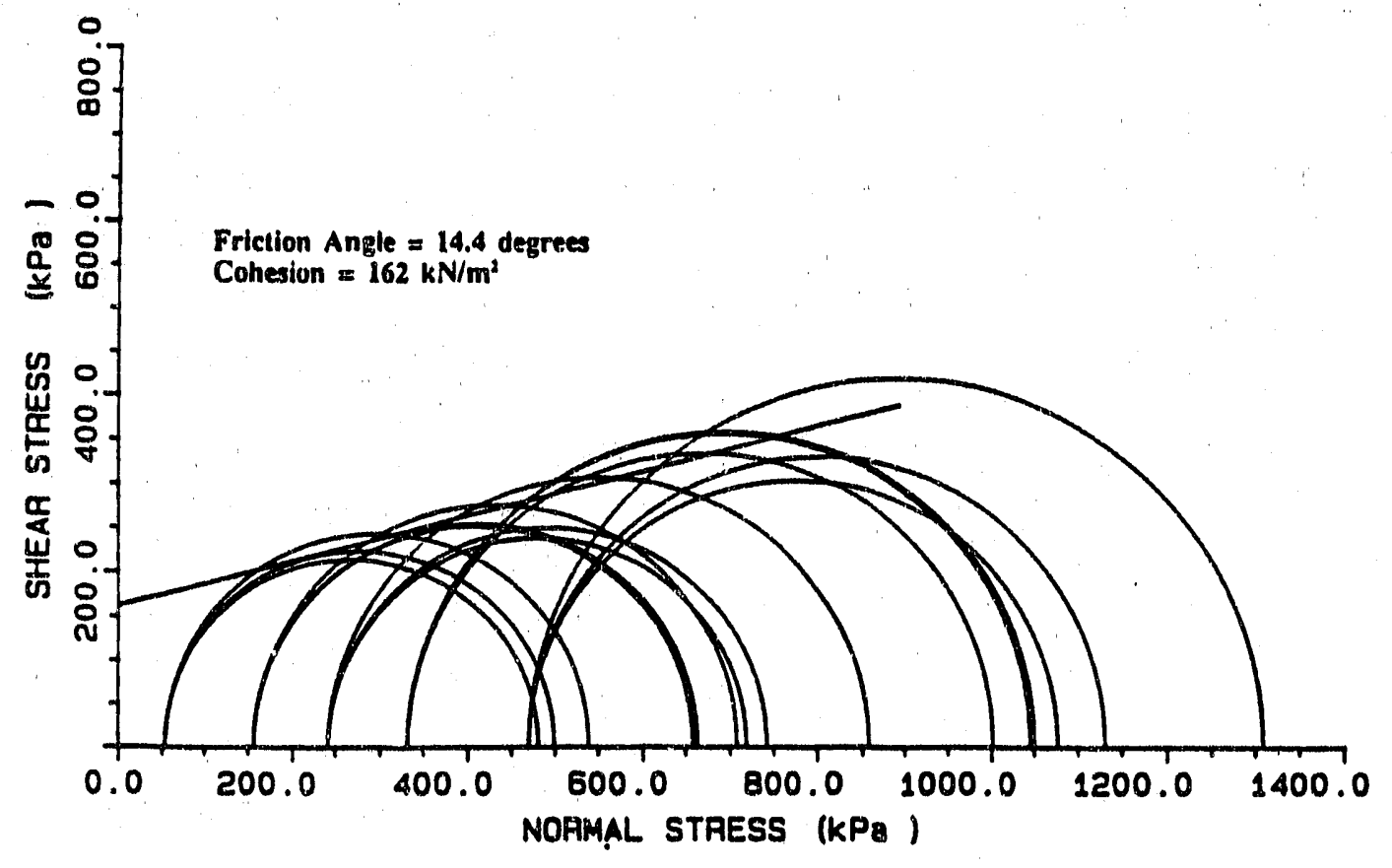

Figure 5.1.2.3.2 Mohr-Coulomb failure envelope from $\mathrm{CU}$ triaxial tests. 
Samples were prepared at four different initial water contents $(15,20,25$, and 30 percent), allowed to cure for four different time periods $(1,7,14$, and 28 days), and then tested in unconfined compression. During the curing period, the samples were wrapped in cellophane to minimize the loss of moisture by evaporation. Three samples were prepared and tested for each of the sixteen combinations of water content and curing time.

Curves of unconfined compressive strength $\left(q_{u}\right)$ versus curing time for each initial water content is presented in Figure $5 \cdot 1 \cdot 2.3 .3$. Each curve is a second order polynomial best fit. The results show an increase in $q_{u}$ with increasing curing time and with increasing initial water content. At initial water contents of 25 and 30 percent, $q_{u}$ apparently would increase even beyond the 28 day period.

\subsubsection{Hydraulic Conductivity}

The movement of water through a processed shale waste embankment is the primary factor controiling the release of potentially harmful leachates into surface and groundwater. The hydraulic conductivity $(k)$ of the processed shale is required to predict the flux and velocity of water movement. The hydraulic conductivity of compacted soils is influenced by a number of factors including molding water content, degree of saturation, compactive effort, void ratio, chemistry of the permeant liquid, age of the soil, and others (Boynton and Daniel 1985). Samples of Lurgi processed shale were tested using the triaxial falling head permeability method to evaluate the influence of compacted density on hydraulic conductivity. In addition, the results of tests conducted by Sri Ranjan and others (1989) were used to evaluate the variation of hydraulic conductivity with water content for Lurgi processed shale.

To evaluate the influence of compactive effort, thirty-five samples of the processed shale were mixed at molding water conterits ranging from 15 to 30 percent (by weight) to achieve dry densities ranging from $12.5 \mathrm{kN} / \mathrm{m}^{3}$ to $14.4 \mathrm{kN} / \mathrm{m}^{3}$, allowed to cure for one day at room 


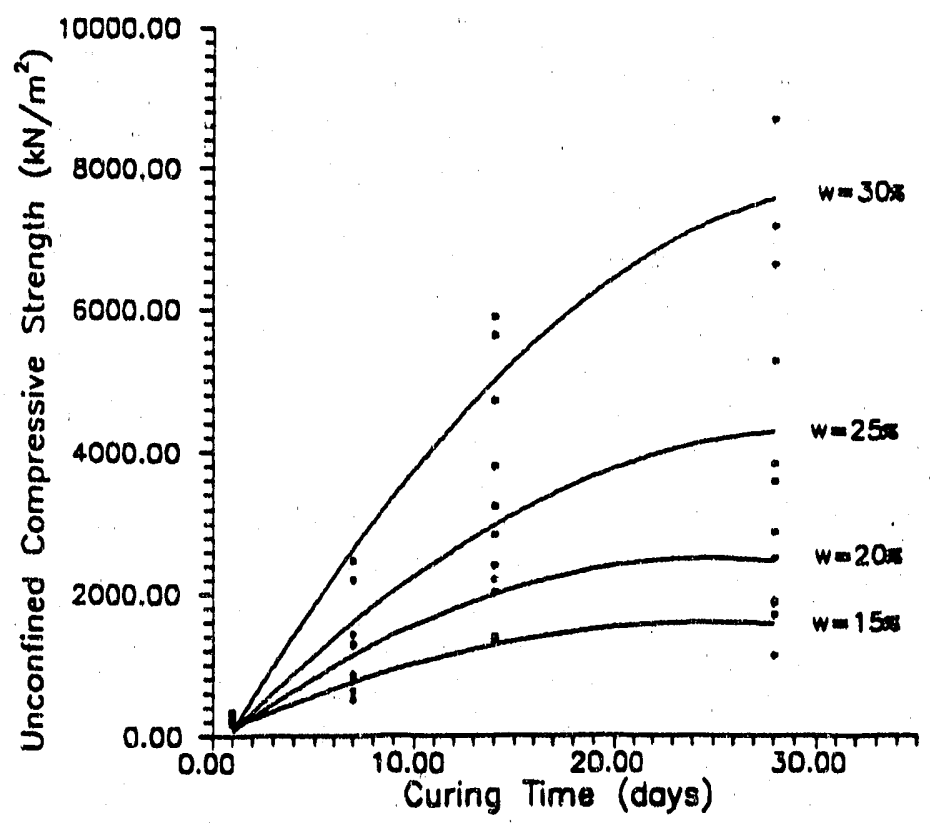

Figure 5.1.2.3.3 Unconfined compressive strength versus curing time. 
temperature and humidity, placed in a triaxial cell under a confining stress of $48.3 \mathrm{kN} / \mathrm{m}^{2}$, and tested for falling head permeability. The results are presented in Figure 5.1.2.4.1 and show a significant decrease in hydraulic conductivity with increasing dry density. The overall decrease is over three orders of magnitude, illustrating the importance of appropriate compaction specifications and field quality control in order to control the hydraulic conductivity of the combusted shale in a disposal embankment.

Sri Ranjan and others (1989) evaluated the saturated hydraulic conductivity of Lurgi processed shale as a function of molding water content and time. Samples mixed at water contents of $0,10,15$, and 20 percent (by weight) and compacted to $14.2 \mathrm{kN} / \mathrm{m}^{3}$ dry density were cured for 90 days in rubber-sleeved permeameter cells, submerged in water to achieve saturation, and subjected to falling head permeability tests over a 216 day period. The results are presented in Figure 5.1.2.4.2 showing saturated hydraulic conductivity versus time for the four different curing water contents. The samples prepared and cured at water contents of 10 , 15, and 20 percent exhibit a much different behavior over time than the samples that started out dry. Upon saturation, the hydraulic conductivity of the initially dry samples decreased by 3 orders of magnitude to approximately $3 \times 10^{-8} \mathrm{~cm} / \mathrm{sec}$ after 216 days. The samples cured at the other water contents did not exhibit the same decrease in hydraulic conductivity. This observed behavior was explained by Sri Ranjan and others (1989) as an "armoring effect" in which incomplete hydration of the processed shale causes large pore spaces occupied by air to be "frozen" into place. Subsequent saturation of the material following curing was effectively prevented. In order to achieve complete hydration and a full reduction in hydraulic conductivity the authors suggest an initial degree of saturation of at least 85 percent.

A similar phenomena was observed in this study when mixing Lurgi-processed shale with water in both field and laboratory tests. At water contents below approximately 25 percent (degree of saturation $=85$ peicent), a portion of the moist mix consists of relatively large 


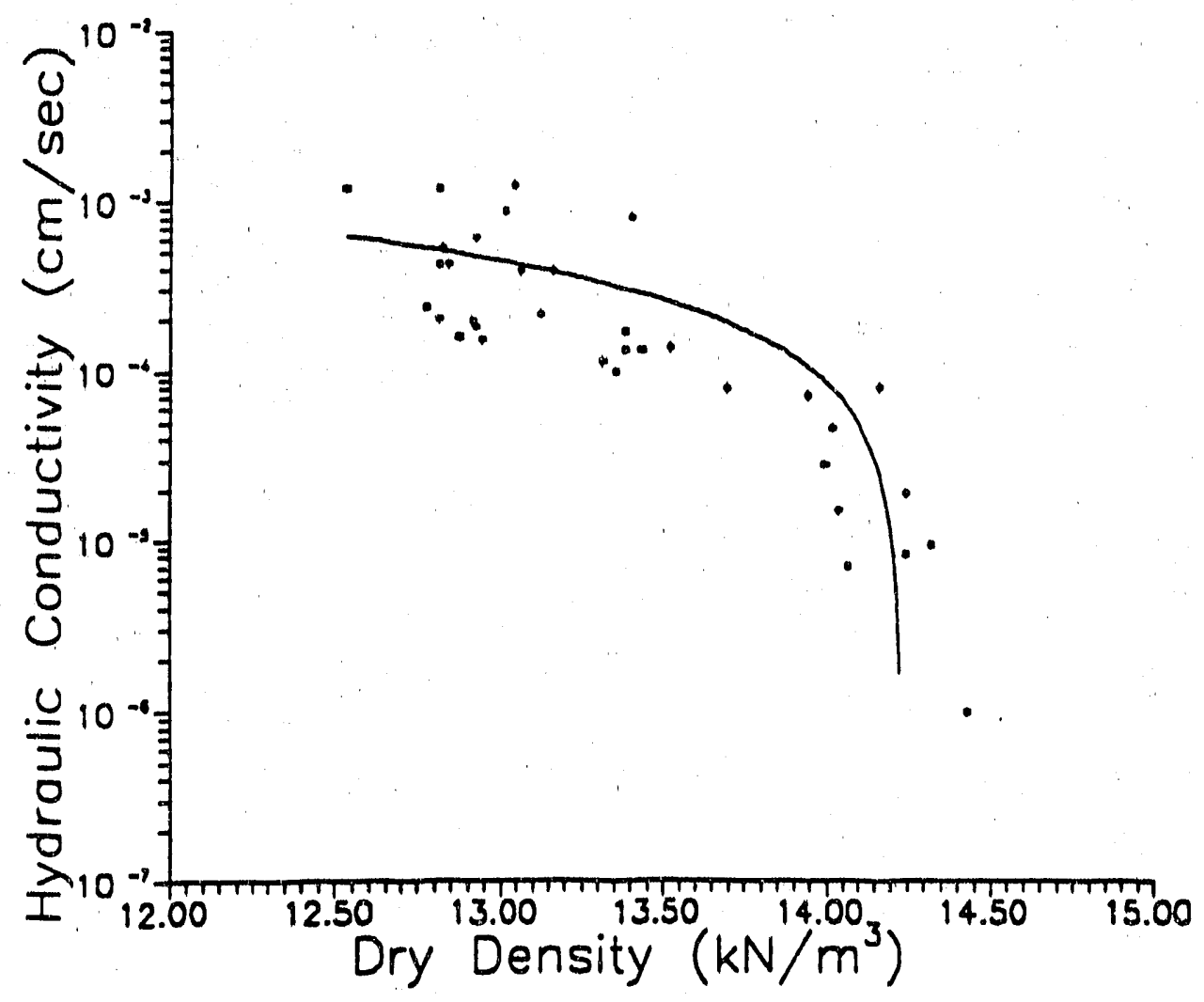

Figure 5.1.2.4.1 Hydraulic conductivity versus dry density. 


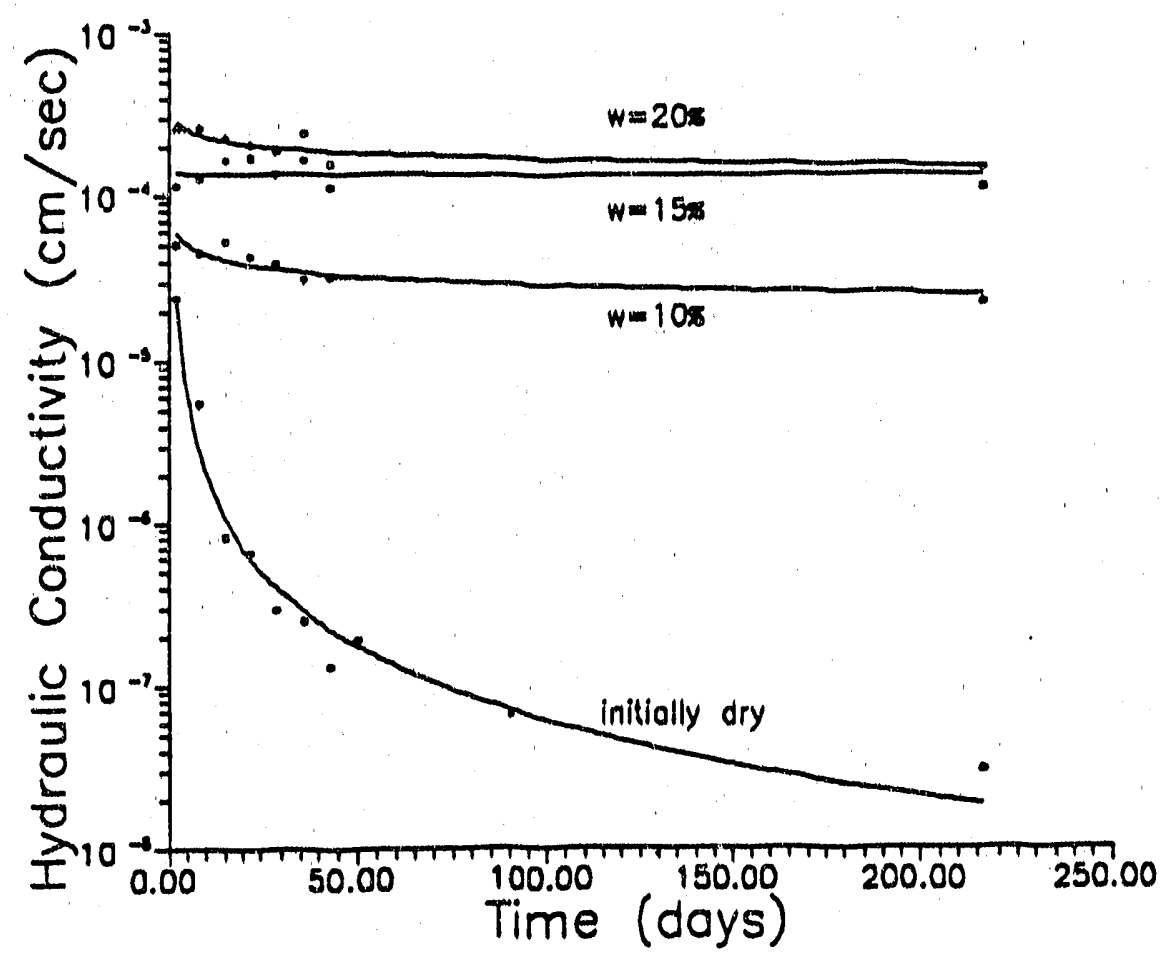

Figure 5.1.2.4.2 Hydraulic conductivity versus time for different curing moisture contents. Data from Sri Ranjan (1989). 
aggregated particles of processed shale (up to $1 \mathrm{~cm}$ in diameter) which are moist on the outside but dry inside. When these aggregated particles are allowed to cure, they consist of a cemented outer shell with dry, unhydrated processed shale inside. The outer shell of these particles can barely be broken between one's fingers. This gives the processed shale the texture of a lightlycemented coarse sand consisting in part of large aggregated particles cemented on the outside, resulting in a relatively high hydraulic conductivity. If the same material is cured at a water content sufficient to allow cornplete hydration, the entire mass becomes highly cemented, the large aggregated particles do not form, and the material becomes practically impermeable. This observation and those of Sri Ranjan and others (1989) demonstrate that cementation is the most significant factor affecting the hydraulic conductivity of laboratory prepared samples of combusted Western oil shale.

For this study, a second group of samples was prepared using soll-cement molds $(2.8$ in dia., 5.6 in high) to evaluate the effects of initial water content and curing time on hydraulic conductivity. The results are presented in Figures 5.1.2.4.3 through 5.1,2.4.6, which show an exponential best fit of the data for $k$ versus curing time, for water contents of $15,20,25$, and 27 percent. Figure 5.1 2.4.7 shows all 4 curves together. As can be seen, the scatter is large and there is no apparent trend of correlation with either water content or curing time. There is a subtle suggestion that $k$ converges to a value berween $10^{-5}$ and $10^{-4} \mathrm{~cm} / \mathrm{sec}$, however the trend is not significant enough to warrant a conclusion on this basis. Further testing may be needed to discern the effects of initial water content and curing time.

Samples prepared in the soil-cement molds are superimposed on Figure 5.1.2.4.1 in Figure 5.1.2.4.8, showing $k$ versus dry density,. These additional results follow the previously observed trend of decreasing conductivity with increasing dry density, but add more scatter. One explanation is that there are differences between the sample populations. Compaction in the soil cement molds yields higher densities than compaction in the Harvard miniature molds, 


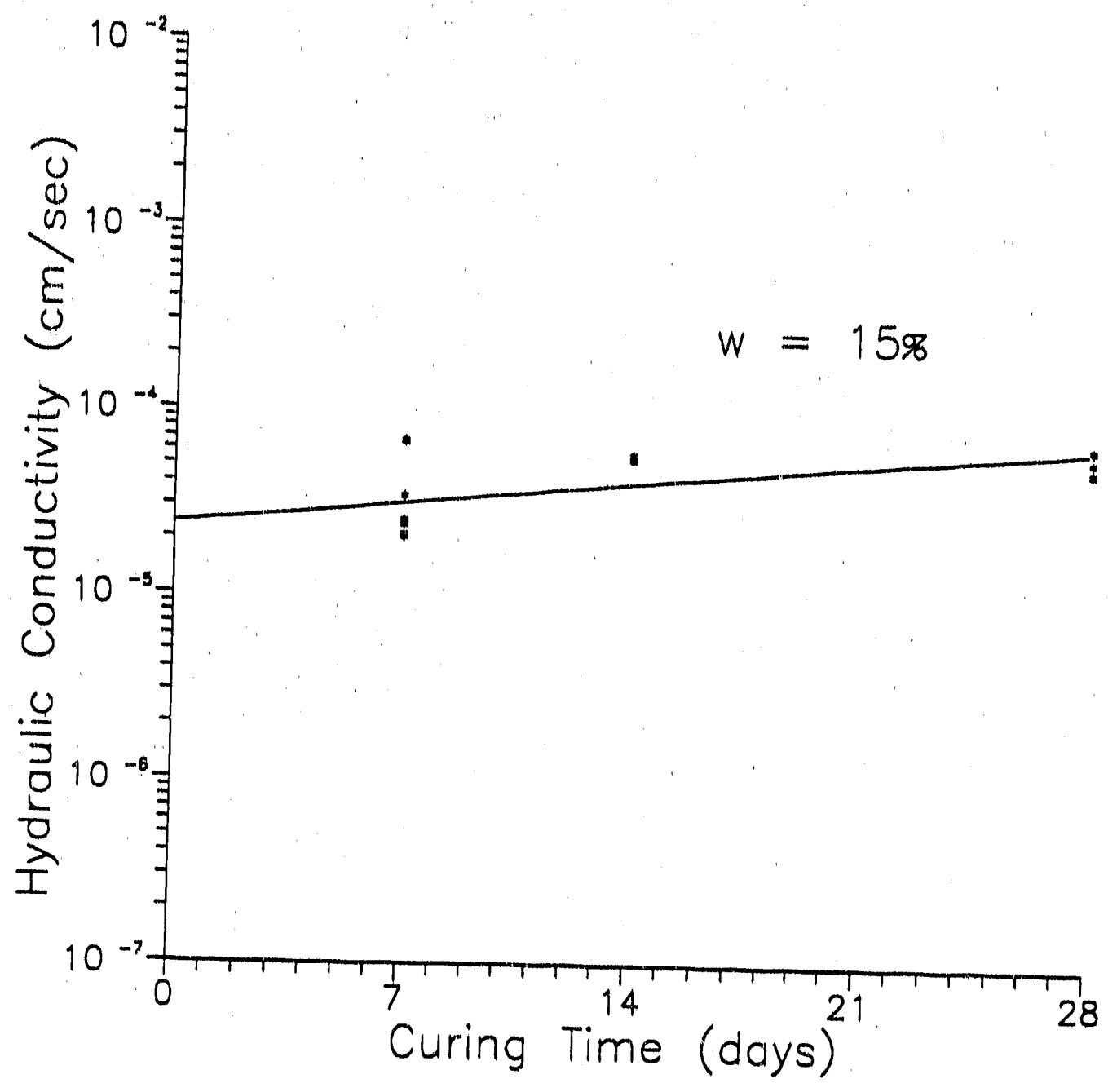

Figure 5.1 2.4.3 Hydraulic conductivity versus curing time for samples prepared at 15 percent water content ( $w / w)$. 


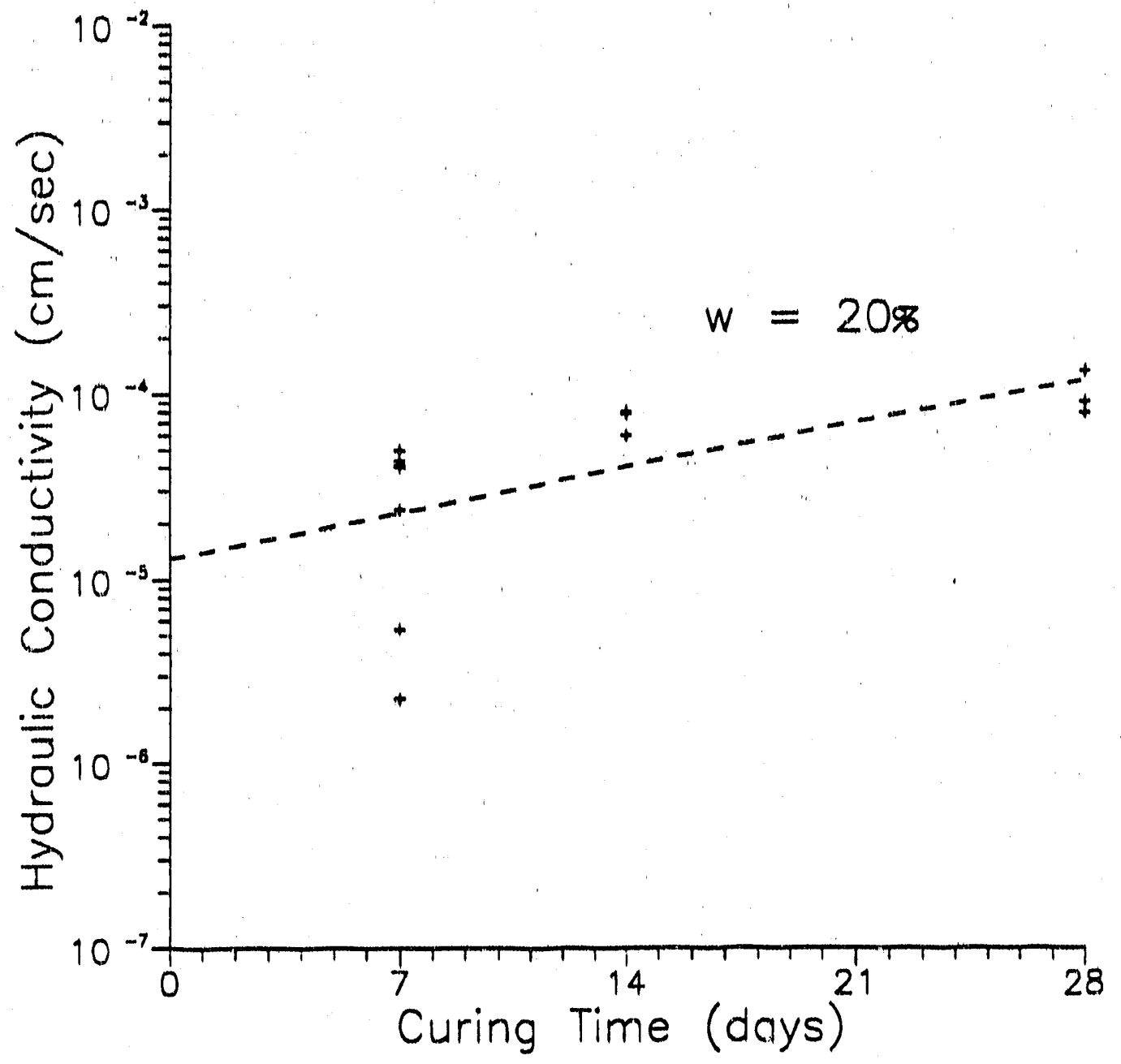

Figure 5.1.2.4.4 Hydraulic conductivity versus curing time for samples prepared at 20 percent water content $(w / w)$. 


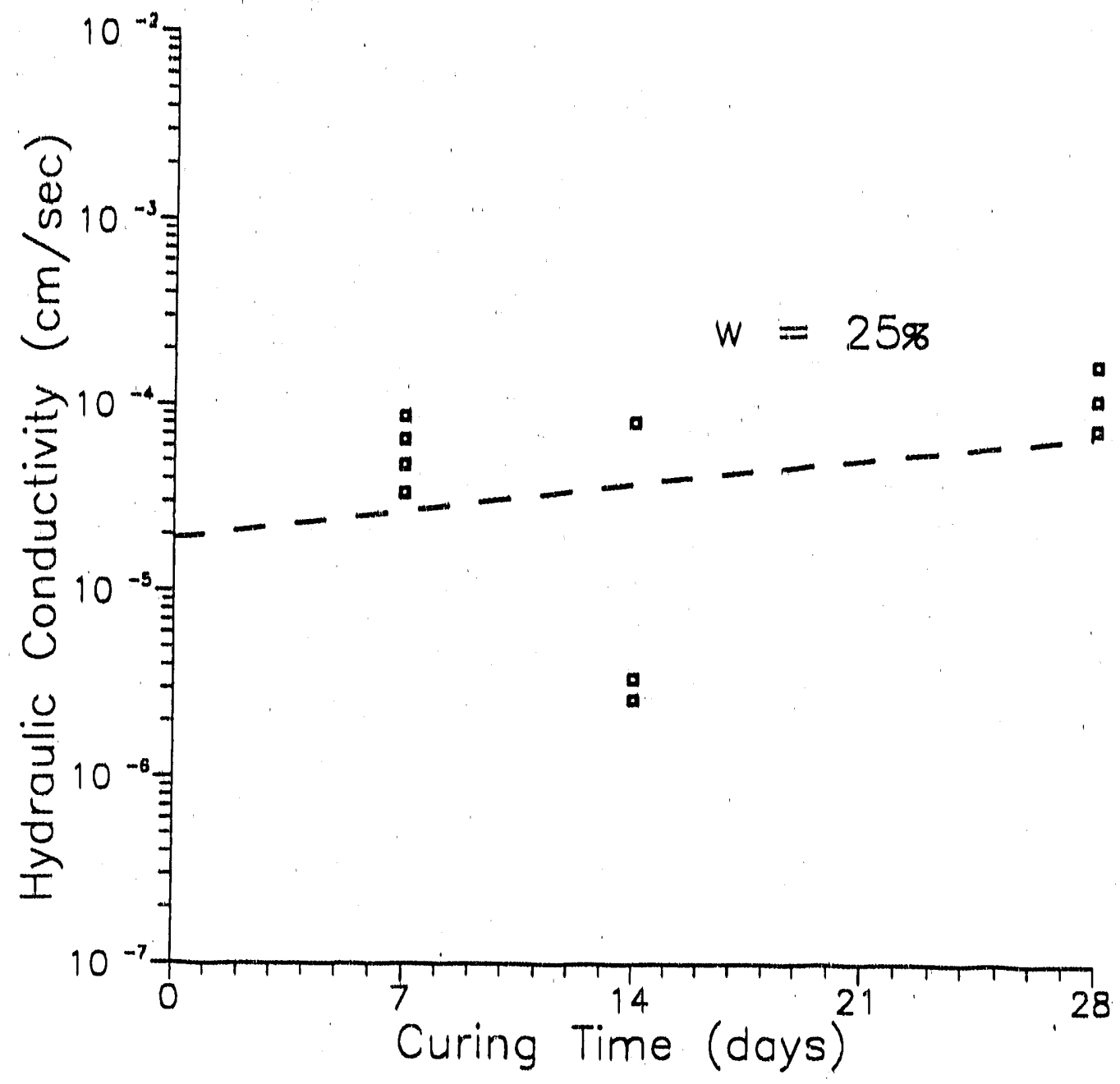

Figure 5.1.2.4.5 Hydraulic conductivity versus curing time for samples prepared at 25 percent water content $(w / w)$. 


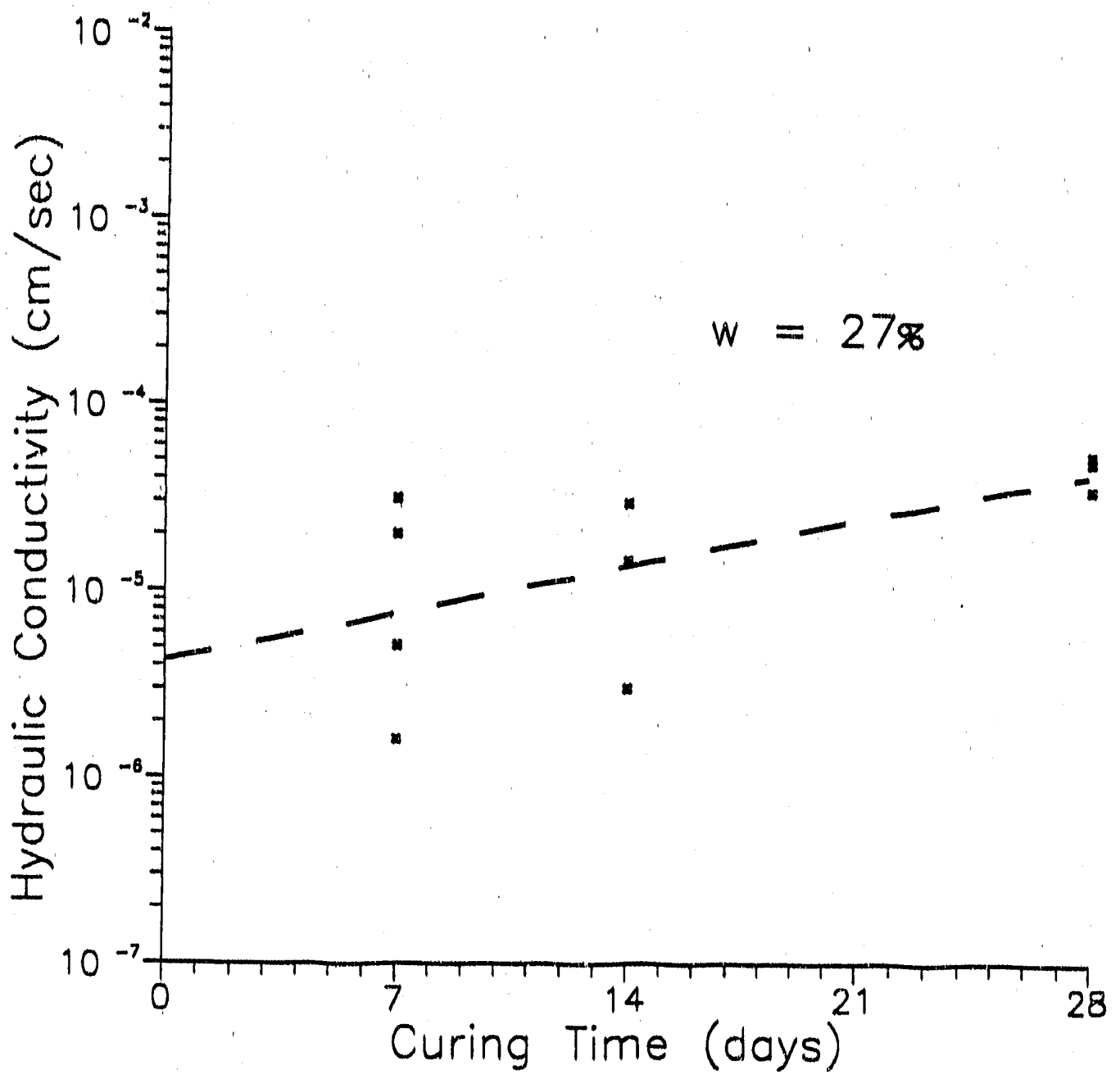

Figure 5.1.2.4.6 Hydraulic conductivity versus curing time for samples prepared at 27 percent water content (w/w). 


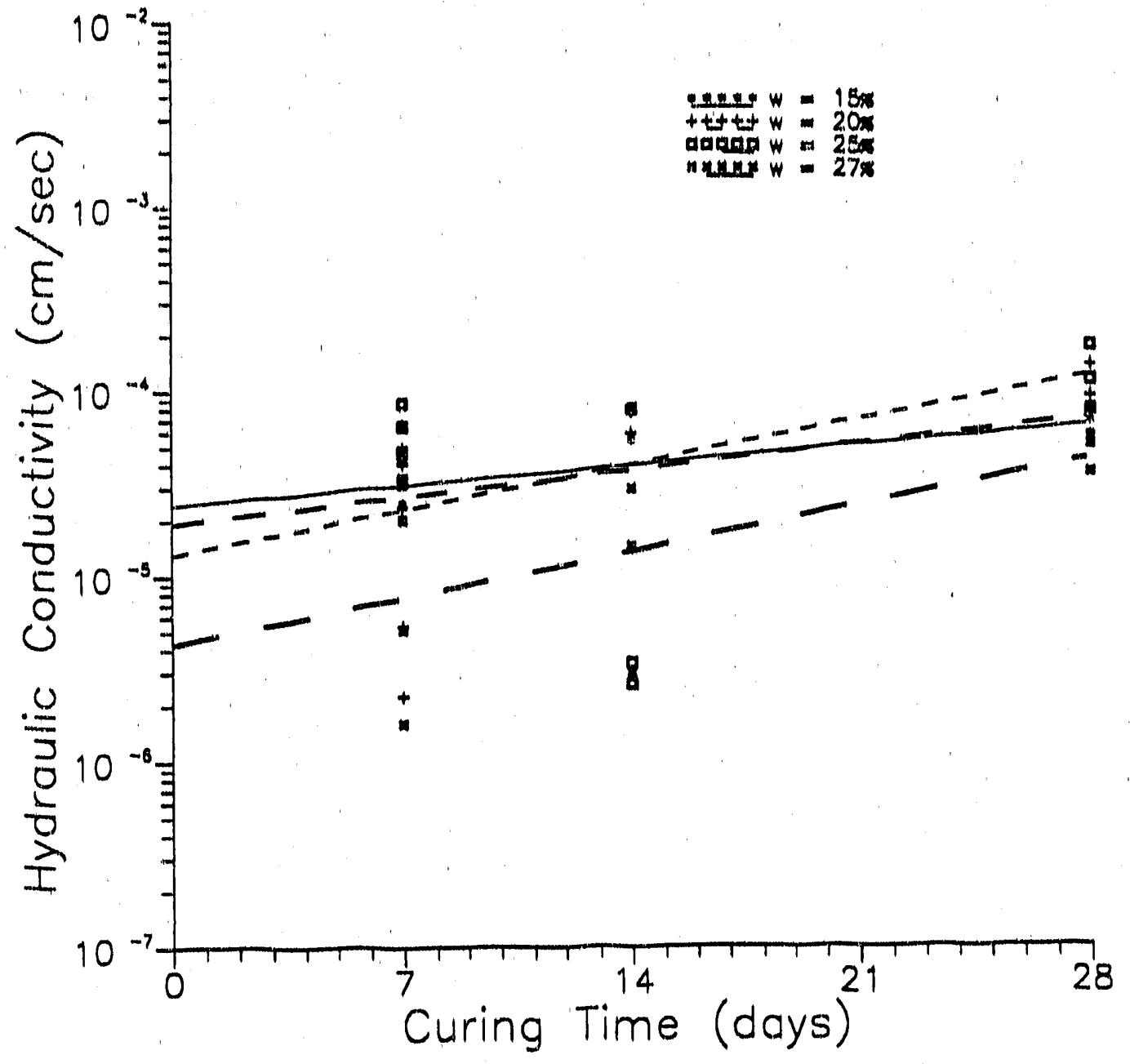

Figure 5.1.2.4.7 Hydraulic conductivity versus ouring time for samples prepared at four different water contents. 


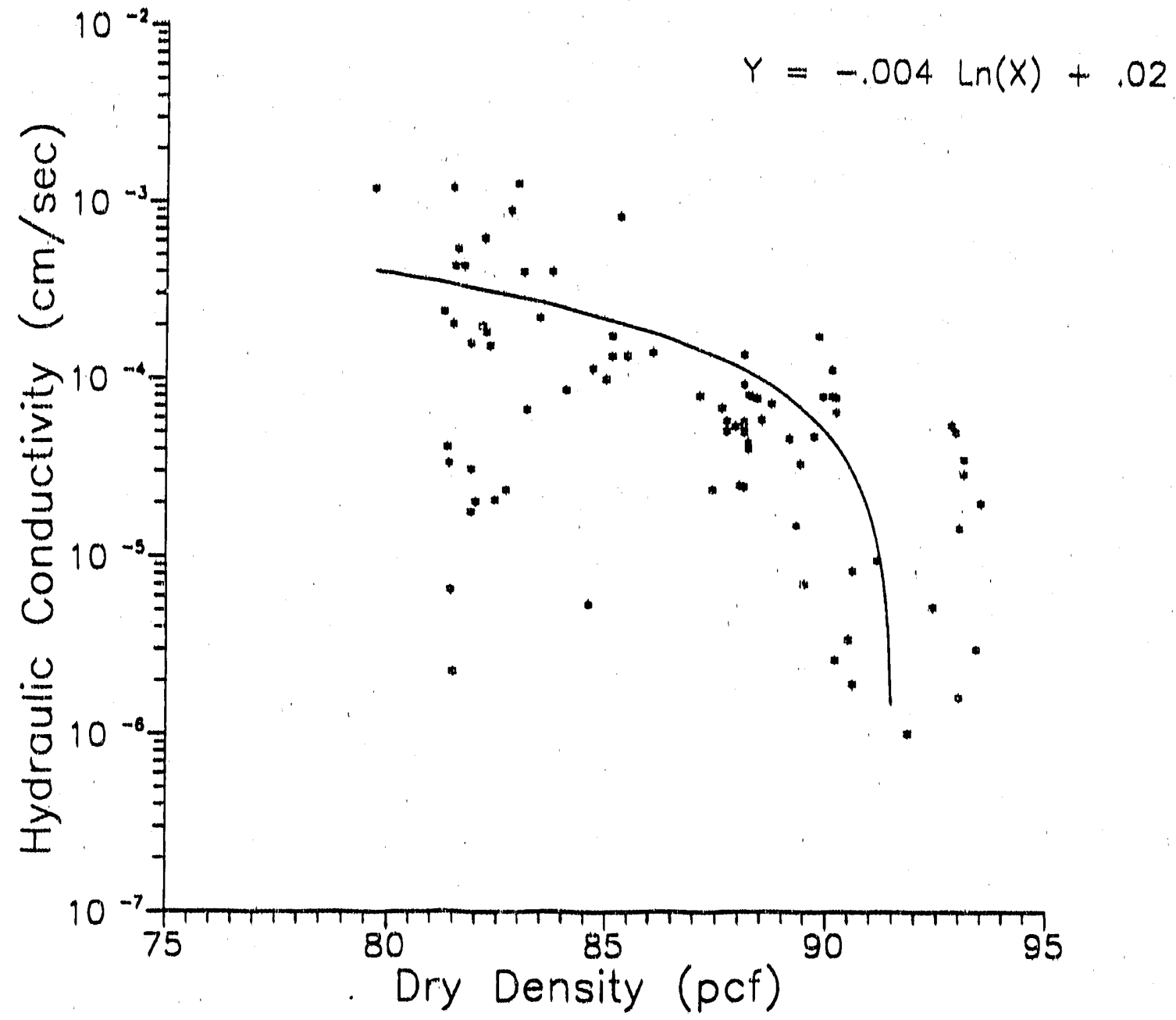

Figure 5.1.2.4.8 Hydraulic conductivity versus dry density. 
for the same water content. Another difference is the variable curing times of the added data points, compared to the i-day cure for the Harvard miniature samples.

\subsubsection{Effects of Weathering}

A total of 30 pairs of samples were subjected to artificial weathering by wet-dry or freezethaw conditions. All samples withstood 12 cycles without failure. Tables 5.1.2.5.1 and 5.1 2.5.2 present the maximum volume change, maximum water content during testing, percent water retained following the final oven drying, and cement loss (as a percentage of total initial sample weight) for each pair of samples. As a comparison, for highway subgrade construction, cernent-stabilized soils are required to withstand 12 cycles with a maximum cement loss of 14\%. All cement losses for the processed shale were well below $14 \%$. Note that the percent water retained is in the range of $3-5 \%$, approximately the percentage of water believed to be bound up by cementation.

Effects on Strength. Following a 28 day curing period, 24 days of weathering, and two saturated hydraulic conductivity tests, one sample from each pair was subjected to a CU triaxial compression test. The resulting total stress Mohr's circles at failure are plotted in Figure 5.1.2.5.1. The weathered samples shew considerably higher strengths than the unweathered samples (Figure 5.1.2.3.2) and the results fall into two groupings. The first group consists of the samples prepared at a water content of $15 \%(w / w)$ and exhibits lower strengths than the second group, prepared and cured at a water content of $2 \% \%$. Apparently, the angle of friction does not change, but the cohesion changes significantly, probably because of cementation. The differences in strength between the weathered and unweathered samples and between the 
Table 5.1.2.5.1 Weathering results, soil-cement Samples at $\theta_{w}=15 \%$.

\begin{tabular}{|c|c|c|c|c|c|c|c|c|c|c|}
\hline & A & B & C & D & $\bar{E}$ & $F$ & $\mathbf{G}$ & $\mathbf{H}$ & 1 & $J$ \\
\hline 1 & WEATHEI & RING & GRES & ULTS & & & & & & \\
\hline 2 & & & & & & & & & & \\
\hline 3 & SA\# & $w$ & $\mathrm{DD}$ & CURE & $E W-D$ Vs. & & Max. Vol. & Max.w & WATER & S_C \\
\hline 4 & & $(\%) 11$ & $(p c i)$ & TIME & F-TH & & Change & $w$ & RETAINED & LOSS \\
\hline 5 & & & & $(w k)$ & & & $(\%)$ & $(\%)$ & $(\%)$ & $(\%)$ \\
\hline 6 & M90-29 & 15 & 87.8 & & $4 W-D$ & & -0.4 & 37.1 & 4.6 & $\ldots$ \\
\hline 7 & M90-30 & 15 & 87.7 & & $4 W-D$ & & $\ldots \ldots$ & $\ldots$ & $\cdots$ & 0.7 \\
\hline 8 & J90-13 & 15 & 88 & & \begin{tabular}{l|l|}
4 & $W \cdot D$ \\
\end{tabular} & & $\begin{array}{r}-1 \\
\end{array}$ & 37.1 & 3.9 & $\cdots$ \\
\hline 9 & $\mathrm{j} 90-14$ & 15 & 88.1 & & $4 \mid W \cdot D$ & & $\ldots$ & 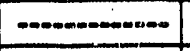 & 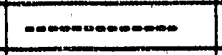 & 3.8 \\
\hline 10 & JU90-14 & 15 & 87.9 & & $4 \bar{W}-D$ & & 0.55 & 35.4 & 3.9 & 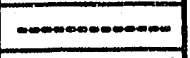 \\
\hline 11 & JU90-15 & 15 & 88.1 & & $\begin{array}{l}4 W-D \\
\end{array}$ & & $\ldots \ldots$ & 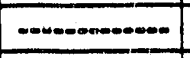 & $\ldots \ldots$ & 4 \\
\hline 12 & M90-27 & 15 & 87.7 & & 4 F.TH & & 4.4 & 39.4 & $\begin{array}{r}4.2 \\
\end{array}$ & $\cdots$ \\
\hline 13 & M90-28 & 15 & 87.9 & & 4 F-TH & & $\ldots$ & $\ldots$ & \begin{tabular}{|c|}
$\ldots \ldots . . . .$. \\
\end{tabular} & 4 \\
\hline 14 & J90-15 & 15 & 88.1 & & $4 /$ F-TH & & 3.9 & 38.7 & 3.9 & $\ldots$ \\
\hline 15 & J90-16 & 15 & 88 & & 4) & & $\ldots$ & $\ldots$ & $\ldots$ & 2.4 \\
\hline 16 & JU90-16 & 15 & 88 & & 4 F.TH & & 2.5 & 38.7 & 3.9 & $-\cdots$ \\
\hline 17 & JU90-17 & 15 & 88.1 & & 4 F-TH & & $\cdots$ & $\ldots$ & $\ldots$ & 0.8 \\
\hline 18 & JU90-27 & 15 & 88.1 & & \begin{tabular}{l|l}
4 & $W-D$ \\
\end{tabular} & & 0.64 & 36.9 & 4 & $\ldots$ \\
\hline 19 & JU90-28 & 15 & 87.9 & & 4 W-D & & $\cdots$ & $\ldots \ldots \ldots$ & $\ldots$ & 3.4 \\
\hline 20 & $190-17$ & 15 & 87.9 & & $4 \mid W-D$ & & -0.6 & 36.9 & 3.9 & $\ldots$ \\
\hline 21 & J90-18 & 15 & 88.1 & & $4 \bar{W}-D$ & & $\ldots$ & 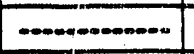 & $\ldots$ & 4.5 \\
\hline 22 & Ju90-3 & 15 & 88 & & $4 W-D$ & & 0.46 & 35.8 & $\begin{array}{r}3.9 \\
\end{array}$ & $\cdots$ \\
\hline 23 & JU90-4 & 15 & 87.9 & & $4 \mid W-D$ & & $\ldots$ & & $\ldots$ & 4.5 \\
\hline 24 & JU90-1 & 15 & 88 & & 4F-TH & & 0.57 & 38.5 & 2.7 & \\
\hline 25 & JU90-2 & 15 & 88 & & 4]F-TH & & $\infty$ & 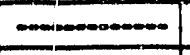 & $\ldots$ & 3.9 \\
\hline 26 & JU90-29 & 15 & 87.9 & & 4/F-TH & & 4.6 & 36.8 & 2.8 & $\infty$ \\
\hline 27 & Ju90-30 & 15 & 88.2 & & 4 F-TH & & $\infty$ & $m$ & $\ldots \ldots$ & 3.2 \\
\hline 28 & $590-19$ & 15 & 88 & & 4 F.TH & & 2.5 & 38.5 & 4.6 & 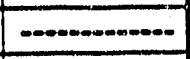 \\
\hline 29 & $190-20$ & 15 & 88.1 & & \begin{tabular}{l|l}
4 F.TH \\
\end{tabular} & & $=$ & $\ldots$ & - & 3.7 \\
\hline 30 & JU90-10 & 15 & 87.9 & & $4 W-D$ & & 0.44 & 35.4 & $\begin{array}{r}3.9 \\
\end{array}$ & \\
\hline 31 & JU90-11 & 15 & 87.8 & & 4 W.D & & $\ldots$ & $\cdots$ & $\ldots$ & 3.8 \\
\hline 32 & $190-5$ & 15 & 88.1 & & $4 W \cdot D$ & & 0.57 & 36.7 & 3.9 & $\ldots$ \\
\hline 33 & $\mathrm{j} 90-6$ & 15 & 88 & & $4 \mathrm{~W}-\mathrm{D}$ & & $=$ & $\cdots$ & 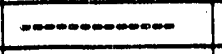 & 3.8 \\
\hline 34 & AU90-1 & 15 & 88 & & 4 W-D & & -0.44 & 36.7 & 4.7 & \\
\hline 35 & AU90-2 & 15 & 88.1 & & $4 W-D$ & & $\ldots$ & $\cdots$ & $\ldots \ldots$ & 4.7 \\
\hline 36 & Ju90-12 & 15 & 88.3 & & 4 F.TH & & 2 & 37.9 & 4.2 & $\cdots$ \\
\hline 37 & Ju90-13 & 15 & 88.1 & & 4 F-TH & & & $\ldots$ & $\ldots$ & 4.7 \\
\hline 98 & J90-7 & 15 & 88.1 & & $\begin{array}{ll}4 \text { F-TH } \\
\end{array}$ & & 2.6 & 37.4 & 4.3 & $\ldots$ \\
\hline 39 & J90-8 & 15 & 88 & & 4 F-TH & & $\cdots$ & $\ldots \ldots$ & - $\cdots \cdots$ & 3.8 \\
\hline 40 & AU90-3 & 15 & 88 & & 4 F.TH & & 1.6 & 38.3 & 4.6 & $\ldots$ \\
\hline 41 & $\longdiv { A \cup 9 0 - 4 }$ & 15 & 88 & & $4 \longdiv { F - T H }$ & & $\ldots$ & $\ldots$ & $\ldots$ & 4.1 \\
\hline
\end{tabular}


Table 5.1.2.5.2 Weathering results, soil-cement samples at $\theta_{w}=27 \%$.

\begin{tabular}{|c|c|c|c|c|c|c|c|c|c|c|}
\hline & A. & B & C & D & $\mathbf{E}$ & $F$ & $\mathbf{G}$ & H & 1 & $J$ \\
\hline \multicolumn{11}{|l|}{1} \\
\hline \multicolumn{11}{|l|}{2} \\
\hline 3 & SA\# & $w$ & $D D$ & CURE & W-D or & & Max. Vol. & Max. & WATER & S-C \\
\hline 4 & & $(\%)$ & (pci) & TIME & F.TH & & Change & $w$ & RETAINED & LOSS \\
\hline 5 & & & & $(w k)$ & & & $(\%)$ & $(\%)$ & $(\%)$ & $(\%)$ \\
\hline 6 & M90.14 & 27 & 93 & & $4 W-D$ & & -0.88 & 31.6 & 4.1 & $\ldots$ \\
\hline 7 & M90-15 & 27 & 93.1 & & $4 W-D$ & & $\cdots$ & $\cdots$ & $\cdots \cdots$ & 4.2 \\
\hline 8 & JU90-23 & 27 & 93.5 & & $4 W-D$ & & -0.85 & 31.3 & 4 & \\
\hline 9 & JU90-24 & 27 & 93 & & $W-D$ & & 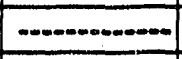 & $-\cdots \cdots$ & $\ldots$ & 4.3 \\
\hline 10 & JU90-25 & 27 & 93.1 & & F-TH & & -0.35 & 31.7 & $\begin{array}{r}4.1 \\
\end{array}$ & $\cdots$ \\
\hline 11 & JU90-26 & 27 & 93.4 & & 4F-TH & & 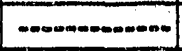 & 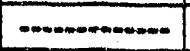 & $\ldots$ & 4.3 \\
\hline 12 & $M 90-12$ & 27 & 93 & & F.TH & & 1.2 & 31.6 & 4.1 & $\cdots$ \\
\hline 13 & M90-13 & 27 & 93 & & AF-TH & & $\cdots$ & $\cdots \cdots$ & $\cdots$ & 4.2 \\
\hline 14 & M90-35 & 27 & 93.2 & & W-D & & -0.85 & 30.3 & 4.1 & $\cdots$ \\
\hline 15 & M90-36 & 27 & 93.3 & & $W-D$ & & $m-\cdots$ & 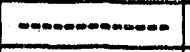 & 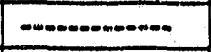 & 3.8 \\
\hline 16 & JU90-35 & 27 & 93.3 & & 4 W-D & & 0.42 & 31.3 & 4.1 & \\
\hline 17 & JU90-36 & 27 & 93.4 & & W-D & & $-\cdots \cdots$ & $\cdots$ & $\cdots$ & 3.8 \\
\hline 18 & M90-33 & 27 & 93.1 & & F-TH & & 0.5 & 31.5 & 4.1 & $\ldots$ \\
\hline 19 & M90-34 & 27 & 93 & & AF-TH & & $\ldots$ & $\ldots$ & $\ldots$ & 3.8 \\
\hline 20 & JU90-33 & 27 & 93.5 & & F.TH & & -0.28 & 32.5 & 3.7 & $\ldots$ \\
\hline 21 & JU90-34 & 27 & 93.7 & & F-TH & & $\infty$ & $\cdots$ & $-\cdots$ & 4.4 \\
\hline 22 & JU90-6 & 27 & 93.1 & & AW-D & & -1.2 & 31.2 & 4.1 & $\ldots$ \\
\hline 23 & JU90-7 & 27 & 93.3 & & W-D & & $\ldots$ & $-\infty$ & $-\infty-000-\infty$ & 3.7 \\
\hline 24 & $190-9$ & 27 & 93.4 & & 4 W-D & & -0.75 & 30.9 & 4.1 & \\
\hline 25 & j90-10 & 27 & 93 & & W-D & & $=$ & $-\infty$ & $-\cdots$ & 3.8 \\
\hline 26. & JU90-8 & 27 & 93.3 & & F-TH & & -0.36 & 32.1 & 4 & \\
\hline 27 & JU90-9 & 27 & 93 & & F-TH & & $\cdots$ & $\infty$ & $\ldots \ldots$ & 3.9 \\
\hline 28 & $190-11$ & 27 & 93.4 & & F-TH & & -0.46 & 32.2 & 4.1 & $\ldots$ \\
\hline 29 & J90-12 & 27 & 93.2 & & F.TH & & $\cdots \cdots$ & $\ldots$ & $\cdots$ & 3.8 \\
\hline 30 & JA90-2 & 27 & 95.1 & & W-D & & 3.3 & 27.9 & 3.5 & $\cdots$ \\
\hline 31 & JA90-3 & 26 & 93.7 & & W-D & & 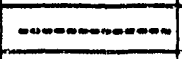 & 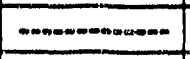 & $\ldots$ & 3.9 \\
\hline 32 & JA90-5 & 27 & 92.6 & & F-TH & & 4.7 & 33.4 & 3.7 & $\cdots$ \\
\hline 33 & JA90-4 & 27 & 92.8 & & 1)F.TH & & $-\infty=0$ & {$[-\infty \cdots \infty$} & $-\infty$ & 3.8 \\
\hline
\end{tabular}




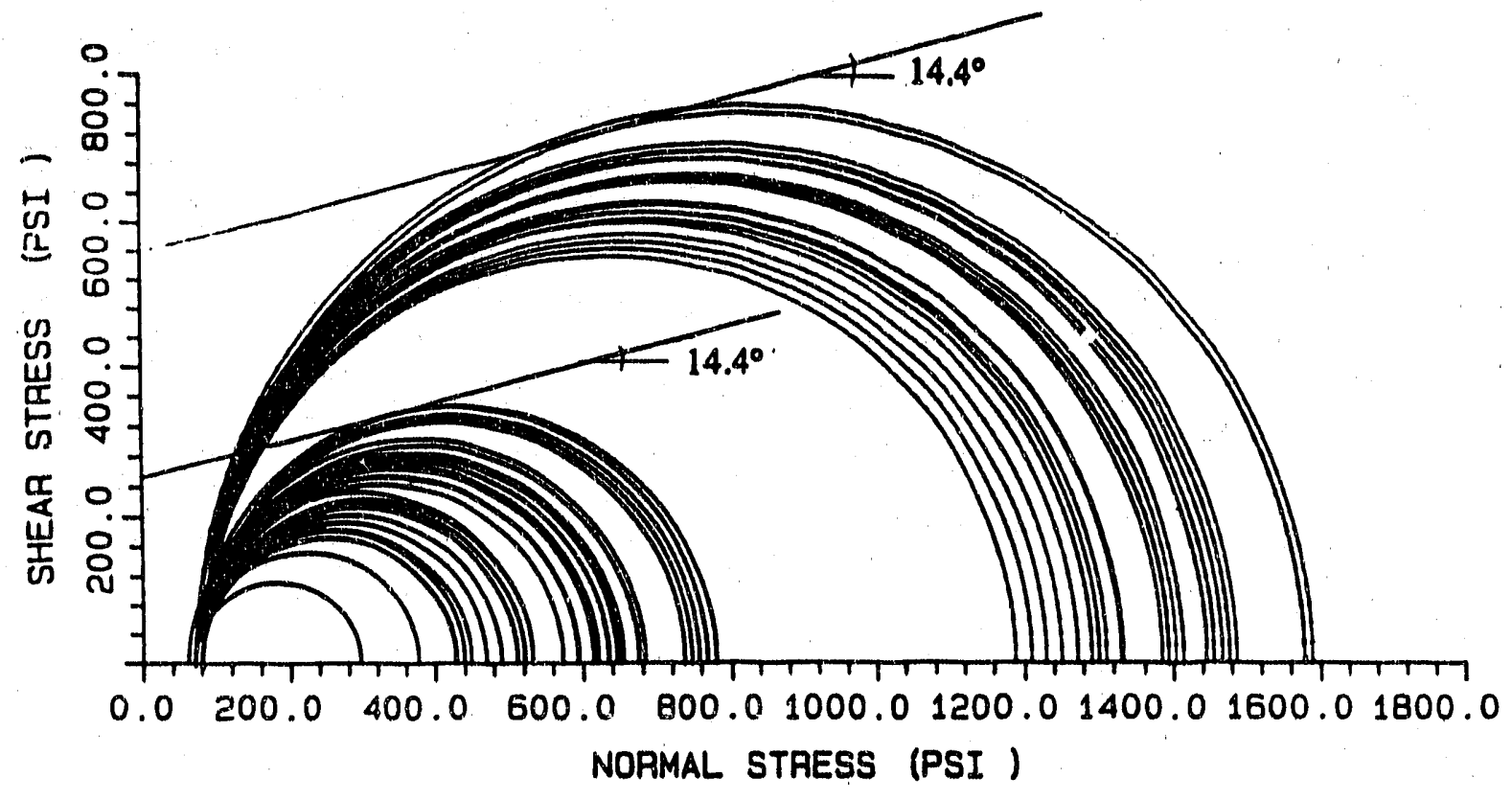

Figure 5.1.2.5. i Results of consolidated undrained triaxial tests on weathered processed oil shale. 


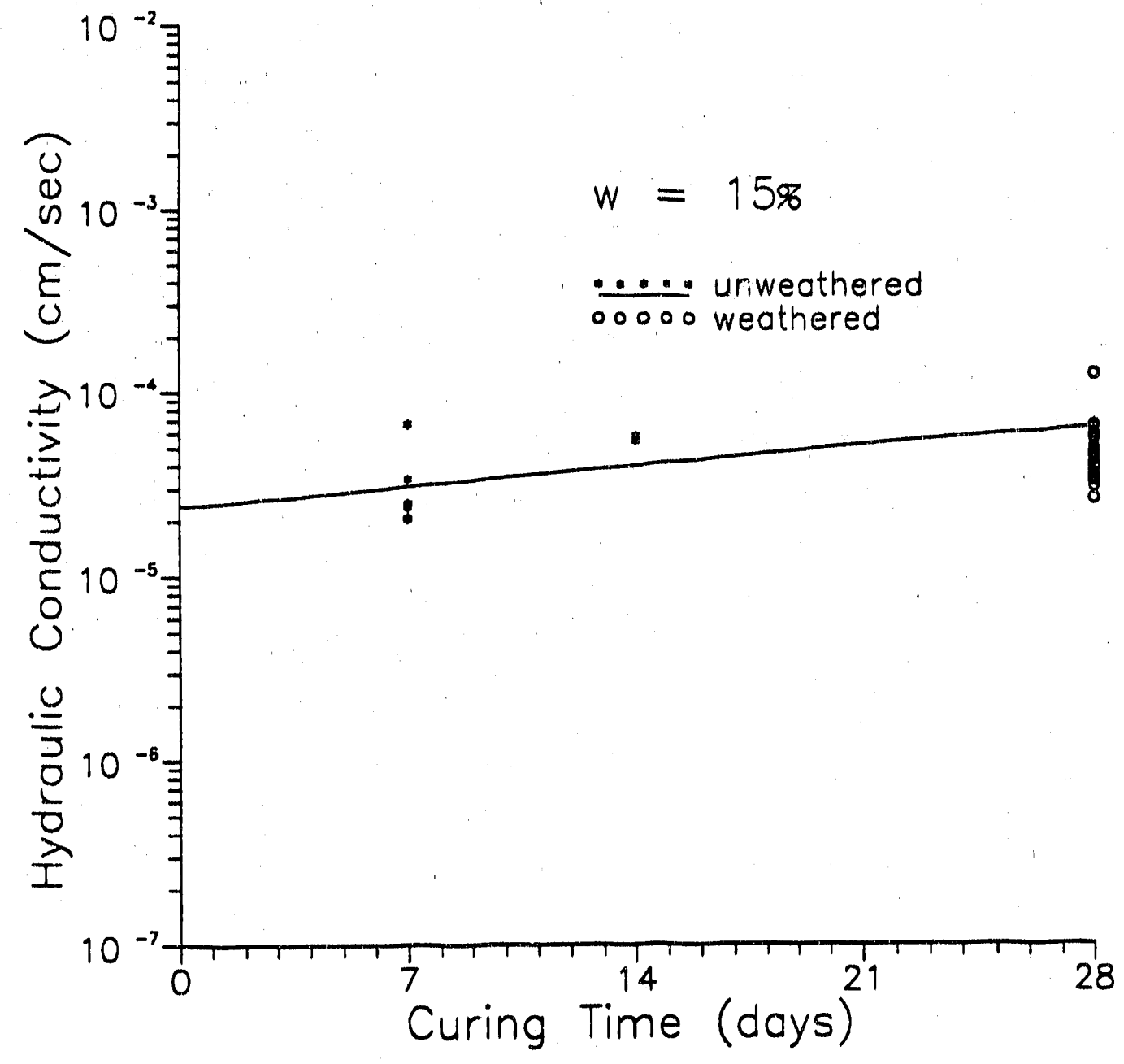

Figure 5.1.2.5.2 Hydraulic conductivity versus curing time for weathered and unweathered samplos at $15 \%$ water content $(w / w)$. 
weathered samples at $\theta_{w}=15 \%$ versus $\theta_{w}=27 \%$ can be explained by the effects of sample preparation and curing on cementation. The unweathered samples were cured for 7 days and then tested in triaxial compression tests. The weathered samples were cured for 28 days, during which time they may have gained significantly higher strengths from cementation, with the samples at $\theta_{w}=27 \%$ developing considerably more cementitious bonding than those at $\theta_{w}=15 \%$. If it is assumed that the undrained friction angle does not change from 14.4 degrees measured on the unweathered samples (Figure 5.1.2.3.2), than the increased cohesion resulting from longer curing times and different water contents of the weathered samples can be seen in Figure $5: 1.2 .5 .1$

At the time of this report, a third group of samples is being prepared to provide a control group for evaluating the effects of weathering. These samples will be cured for the same number of days as the weathered samples $(28+24=52$ days $)$, tested for saturated hydraulic conductivity, and then tested in triaxial compression. This will provide a more consistent comparison with the weathered samples. These data will be discussed in the final report for this project.

Effects on Hydraulic Conductivity. Each of the 60 samples was subjected to falling head hydraulic conductivity tests following curing and wet-dry or freeze-thaw weathering. Eighteen samples were prepared at $\theta_{w}=15 \%$ and 12 were prepared at $\theta_{w}=27 \%$. The results are plotted with unweathered samples in Figures 5.1.2.5.2 and 5.1.2.5.3. Comparing Figures 5.1.2.4.2 and 5.1.2.5.3, there is no observable effect due to weathering for samples prepared at $\theta_{w}=15 \%$. The weathered samples prepared at $\theta_{w}=27 \%$ show considerable scatter and no effect can be concluded. Four additional samples weathered for 7 days are also presented in Figure 5.1.2.5.3. 


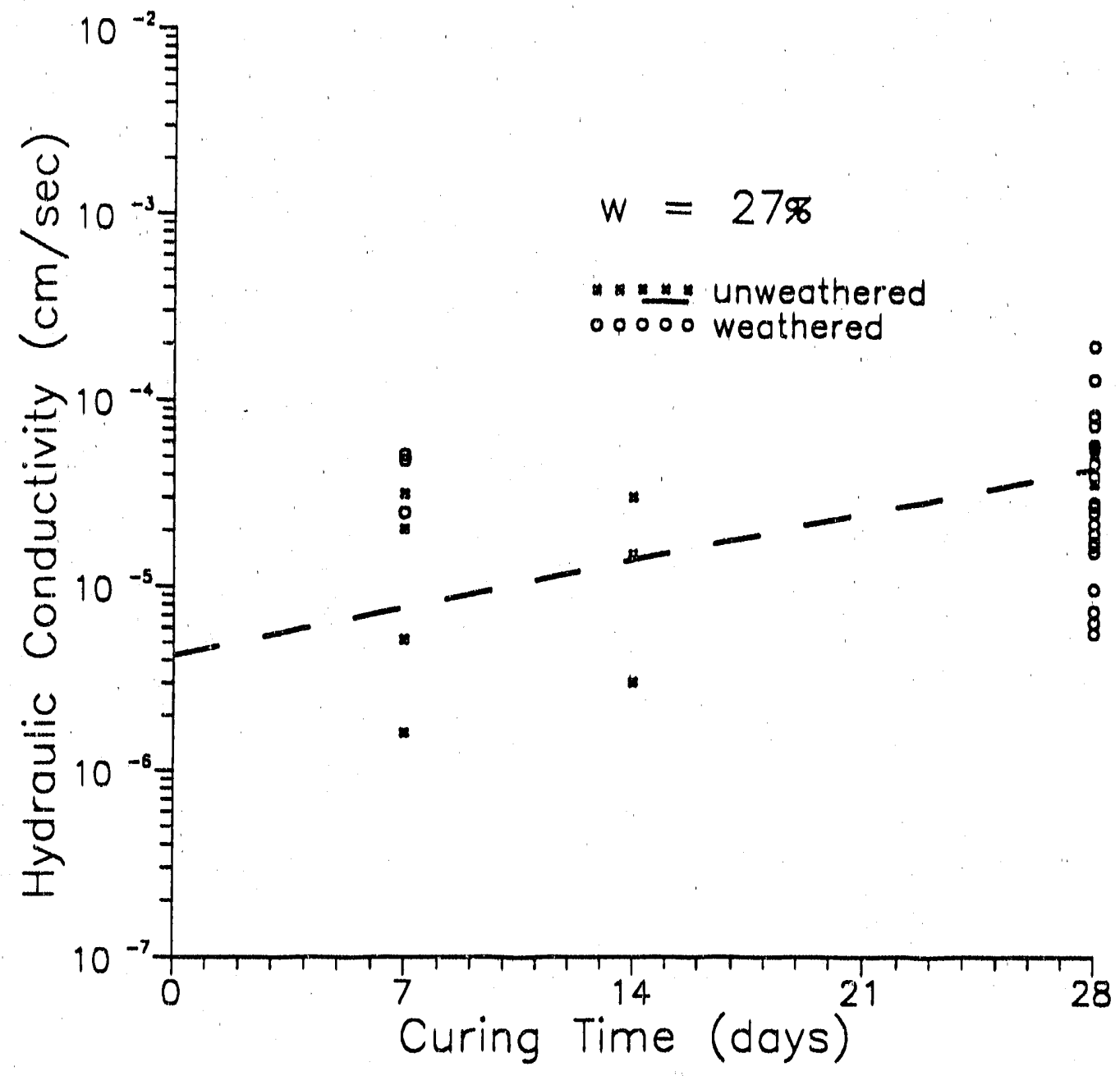

Figure 5.1.2.5.3 Hydraulic conductivity versus curing time for weathered and unweathered samples at $27 \%$ water content $(w / w)$. 


\subsubsection{Moisture Characteristic Curves}

Two tests were conducted using the 15 bar apparatus. The results were essentially identical from the two tests (Figure 5.1.2.6.1). Two additional tests were conducted using the 2 bar apparatus and the results are shown in Figure 5.1.2.6.2. Each 2 bar test consisted of one cycle of draining and filling. In the first test, the direction of hysteresis was observed to be opposite of the expected behavior. For most pressures, the measured water contents were higher for the filling curve than the draining curve. The second test exhibited more typical behavior and is believed to be more representative of the processed shale behavior.

One possible explanation for the atypical behavior observed in the first test is that it was conducted over a period of 6 months. The relatively long period for this test was a result of some equipment breakdown and because of operator inexperience. It is possible that significant hydration and cementation of the processed shale occurred during this six month period which the test was being conducted. Cementation would have changed the material properties such as the porosity and the hydraulic conductivity dramatically effecting the results. A more thorough discussion of cementation is presented in section 5.1.3. The second test was conducted over a period of 2 weeks. Because of the variability between the results to date, a best fit curve through all of the data points was used for estimating soil suctions less than 2 bars in the processed oil shale in the lysimeters. Further tests were being conducted at the time of this report to determine more accurately soil moisture characteristic curves for 2 bars, including hysteresis.

\subsubsection{DISCUSSION OF CEMENTATION PROPERTIES}

The cementing characteristics of a combusted Western oil shale have a strong influence on its geotechnical properties, especially unconfined compressive strength and hydraulic conductivity. Cementation is a function of the chemical/mineralogical changes that occur when 


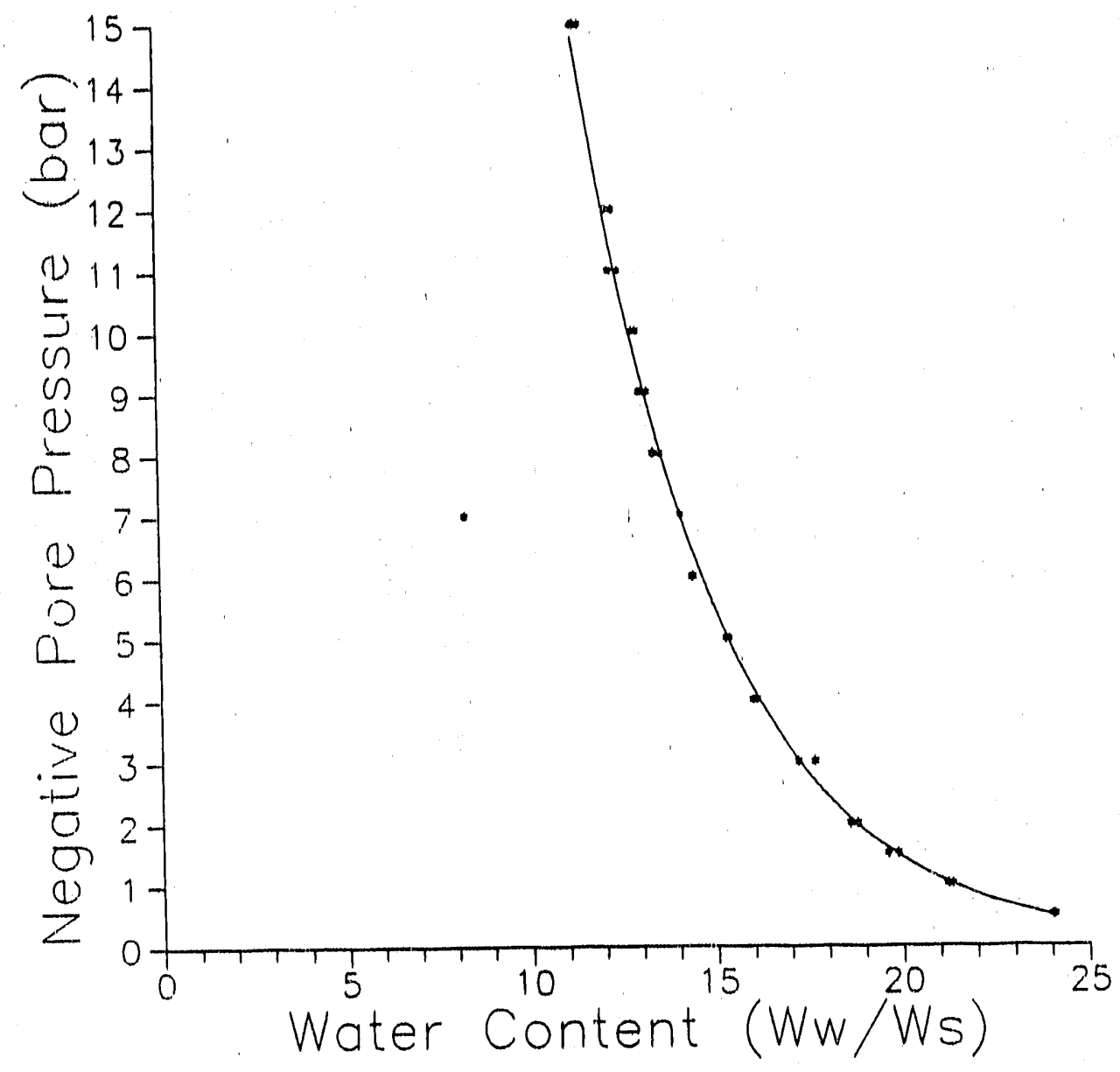

Figure 5.1.2.6.1 Soil moisture characteristic curve for 0 to 15 bar's $(0-1,500 \mathrm{kPa})$. 


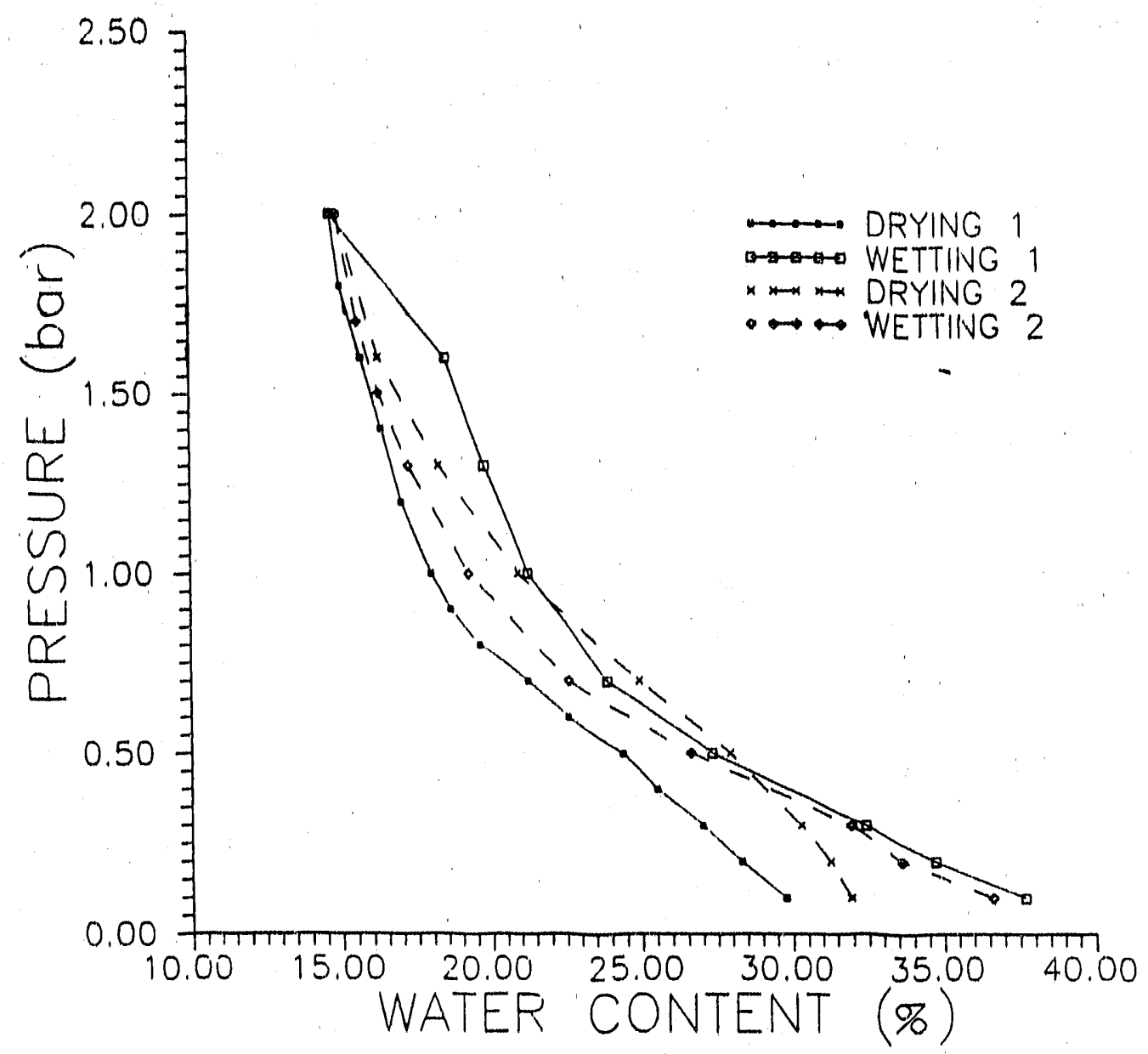

Figure 5.1.2.6.2 Soil-moisture characteristic curve for 0 to 2 bars $(0-200 \mathrm{kPa})$. 
raw ail shale is combusted and then the combusted processed shale is mixad with water.

The inorganio mineral matrix of oll shale from the Green River Formation consists essentially of dolomite, calcite, llite, and quartz, with minor amounts of feldspars, pyrite, and analcime (Prien 1980). Dolomite is calcium magnesium carbonate and calcite is calcium carbonate. When calcium carbonate is heated to combustion temperatures, some loss of $\mathrm{CO} 2$ occurs, producing quicklime, $\mathrm{CaO}$. When mixed with water, quicklime forms calcium hydroxide, $\mathrm{Ca}(\mathrm{OH})_{2}$, also referred to as hydrated lime. Hydrated lime reacts with pozzolanic silica and aluminum oxides to form cementitious calcium silicates and calcium aluminates. These compounds are very stable materials that increase in strength with time, and are referred to as hydrous cements (Eglinton 1987). In Green River Formation oil shale, the source of the calcium carbonate for the formation of lime could be calcite and/or dolomite." The pozzolanic silica and aluminum oxides may be derived from the clay mineral illite (aluminum silica) and/or quartz $\left(\mathrm{SiO}_{2}\right)$, and the thermal decomposition of pyrite may vield sulfur.

Culbertson and others (1970), using Green River Formation oil shale combusted at temperatures ranging from 593 to 927 degrees $C$ and then hydrated at water contents of 5 to 20 percent, identified tobermorite (a gel of calcium silicate hydrates), low sulfate-sulfoaluminate, and ettringite (high-sulfate tricalcium sulfoaluminate), each of which also is present in hydrated Portland cement (Eglinton 1987). Marcus and others (1985), using Green River Formation oil shale from Piceance Basin combusted at 700 degrees $C$, attributed cementation to the growth of crystalline bridges between the processed shale particles. The main mineralogical changes observed during curing at 20 percent water content were the dissolution of anhydrite and hydrolysis of periclase, two minerals present in the combusted shale that are not present in the raw oil shale. The bridging materials were analyzed using scanning electron microscope and consisted of calcium and magnesium carbonates or hydroxycarbonatesand complex aluminum and silicon compounds of the alkaline earth elements. The formation of these bridging materials 
appeared to be time-dependent and corresponded to increases in the unconfined compressive strength, similar to those reported in this paper. Marcus and others (1.985) reported that the mineral ettringite is not present in hydrated processed shale, in disagreement with the results of Culbertson and others (1970).

As part of a cooperative agreement with the U.S. Department of Energy, Western Research Institute (WRI) conducted a study to evaluate the chemical and mineralogical properties of Lurgi processed shale. The ultimate goal was to relate these properties to engineering properties evaluated by this study, including strength and hydraulic conductivity. Although several technical progress reports were issued by WRI, the results were not sufficient to develop correlations between engineering and chemical/mineralogicalproperties. The most recent report (Brown and Brown, 1991) concluded:

"The X-ray diffraction data were difficult to interpret because of the amount of amorphous material present in the samples. A positive identification of the material responsible for the increase in cementation over time was not possible. The XRD data show that calcite $\left(\mathrm{CaCO}_{3}\right)$ is a major component of the system and may in some way be responsible for the cementation process. Minor amounts of gypsum may also contribute to the increase in cementing through the formation of ettringite and other minerals."

The chemical/mineralogical changes that occur when raw shale is combusted and then hydrated have not been determined precisely as a function of combustion temperature, molding water content, and curing time, and are not understood completely. Nevertheless, it is apparent from the chemistry and mineralogy of the raw shale and that of the processed shale that the formation of calcium silicates, calcium aluminates, and possibly calcium and magnesium carbonates are responsible for cementing, and that the time-dependent formation of the 
cementing compounds corresponds to the time-dependent increases in compressive strength and decreases in hydraulio conductivity. From a waste management point of view, it is desirable to exploit the cementitious properties to design stásle and environmentally safe disposal piles.

\subsection{LYSIMETER TESTING PROGRAM}

\subsubsection{HYDROLOGIC ANALYSES}

The method of back calculating unsaturated hydraulic conductivity from in situ water content data was described by Everett et al. (1984). The use of this method as applied in processed oil shale and over the time frames utilized may need to be verified by further analysis. Verification will include the identification of potential sources of error, establishment of specific boundary conditions for application of the method, and the development of a more refined and reliable soil moisture characteristic curve to convert measured water content $\left(\theta_{v}\right)$ to negative pore water pressures. The back calculated values of $k$ will also be compared with in situ methods, including a Guelph permeameter as well as $k$ measured using bench-scale samples prepared in the laboratory.

Tables 5.2.1.1 through 5.2.1.8 summarize the results of hydrologic analyses for each instrument replication at both the RBOSC field site and in the ESL. Figures 5.2.1.1 through 5.2.1.4 are plots of hydraulic conductivity versus water content for ceils 1 and 2 at the field site and cells 1 and 2 of the ESL. There appears to be a general trend of increasing conductivity with increasing water content, but there is too much scatter in the data to make definitive conclusions regarding the relationship between $k$ and water content $\left(\theta_{v}\right)$. 
Iable 5.2.1.1 Hydrologic data analyses by date for cell 1 replication 1 at RBOSC.

\begin{tabular}{|c|c|c|c|c|c|}
\hline $\begin{array}{l}\text { Time } \\
\text { Period }\end{array}$ & $\begin{array}{r}\text { De } \\
\text { Int } \\
10\end{array}$ & & $\begin{array}{c}\text { Mean } \\
\text { Hydraulic } \\
\text { Gradient }\end{array}$ & $\begin{array}{c}\text { Mean } \\
\text { Water } \\
\text { Content } \\
(\%)\end{array}$ & $\begin{array}{l}\text { Mean } \\
\text { Hydraullc } \\
\text { Conductivity } \\
\text { (cm/sec) }\end{array}$ \\
\hline 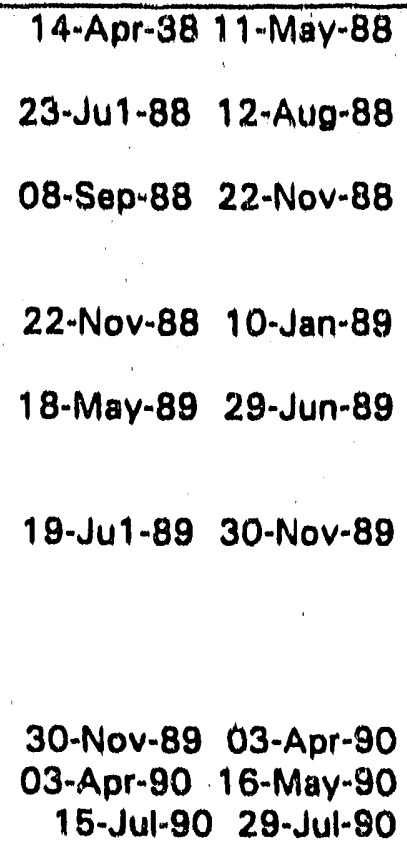 & $\begin{array}{l}30 \\
46 \\
46 \\
61 \\
30 \\
61 \\
76 \\
15 \\
30 \\
15 \\
61 \\
76 \\
15 \\
30 \\
46 \\
61 \\
76 \\
76 \\
76 \\
15\end{array}$ & $\begin{array}{r}46 \\
61 \\
61 \\
76 \\
61 \\
76 \\
168 \\
30 \\
46 \\
30 \\
76 \\
168 \\
30 \\
46 \\
61 \\
76 \\
168 \\
168 \\
168 \\
30\end{array}$ & $\begin{array}{r}1.3 \\
-3.5 \\
-7.7 \\
7.7 \\
-4.2 \\
5.6 \\
-10.9 \\
-12.3 \\
5.7 \\
9.5 \\
3.3 \\
-12.0 \\
-12.0 \\
1.7 \\
-9.4 \\
10.3 \\
-12.8 \\
-12.9 \\
-8.3 \\
-4.7\end{array}$ & $\begin{array}{l}30.2 \\
30.2 \\
28.0 \\
28.4 \\
26.7 \\
26.8 \\
22.8 \\
24.7 \\
24.0 \\
27.3 \\
26.8 \\
22.4 \\
25.1 \\
24.2 \\
23.8 \\
24.1 \\
20.7 \\
21.2 \\
24.2 \\
25.3\end{array}$ & $\begin{array}{l}2.1 \mathrm{E}-06 \\
8.2 \mathrm{E}-07 \\
6.3 \mathrm{E}-07 \\
4.5 \mathrm{E}-07 \\
7.1 \mathrm{E}-07 \\
3.1 \mathrm{E}-07 \\
5.7 \mathrm{E}-07 \\
4.2 \mathrm{E}-07 \\
7.4 \mathrm{E}-07 \\
3.1 \mathrm{E}-07 \\
7.6 \mathrm{E}-07 \\
9.6 \mathrm{E}-07 \\
6.2 \mathrm{E}-08 \\
6.3 \mathrm{E}-07 \\
1.4 \mathrm{E}-07 \\
1.2 \mathrm{E}-07 \\
4.0 \mathrm{E}-07 \\
5.9 \mathrm{E}-07 \\
7.1 \mathrm{E}-07 \\
2.0 \mathrm{E}-06\end{array}$ \\
\hline
\end{tabular}


Table 5.2.1.2 Hydrologic data anslyses by date for cell 1 replication 2 at RBOSC.

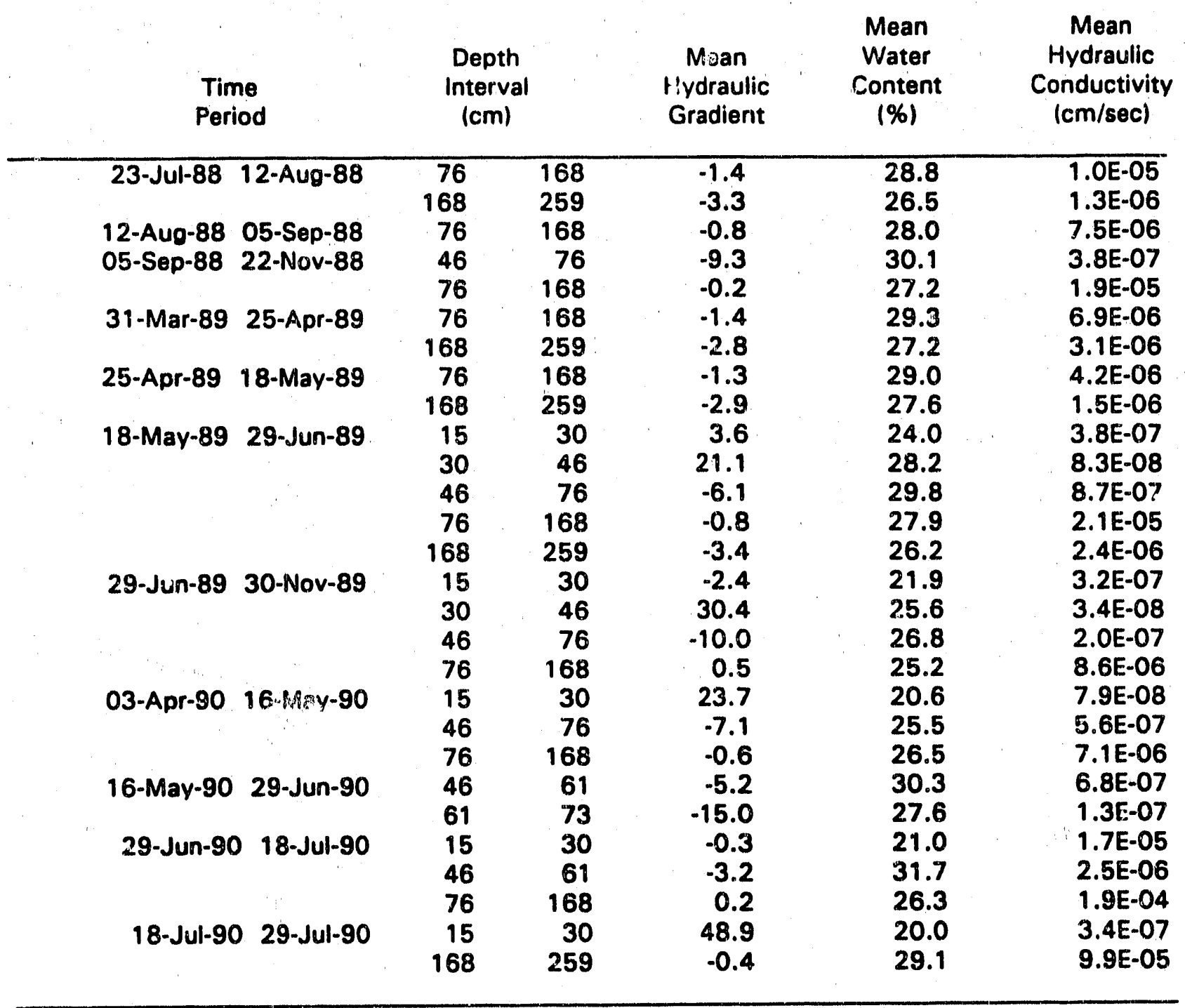


Table 5.2.1.3 Hydrologic data analyses by date for cell 2 replication 1 at RBOSC.

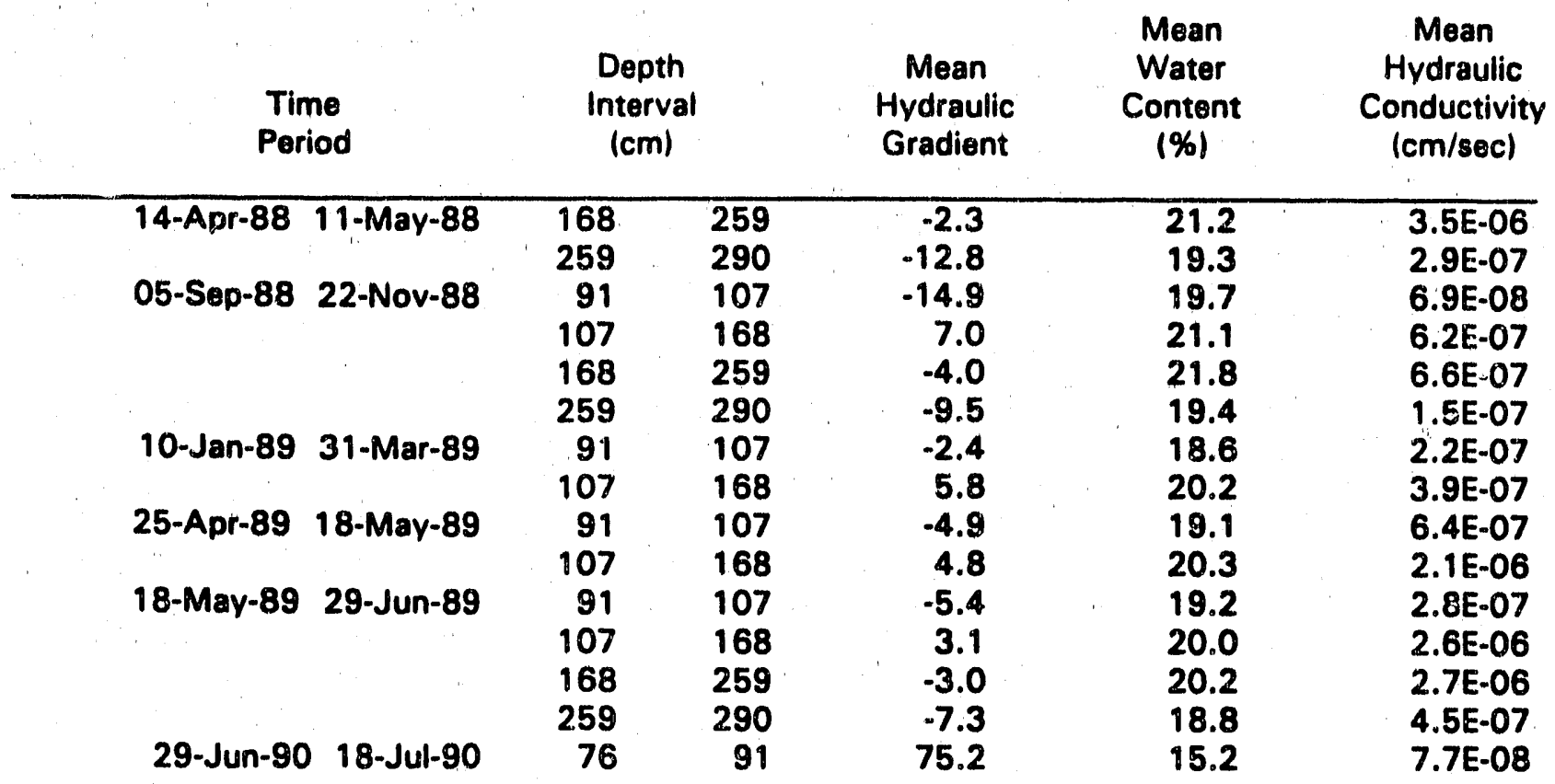

Table 5.2.1.4 Hydrologic data analyses by date for cell 2 replication 2 at RBOSC.

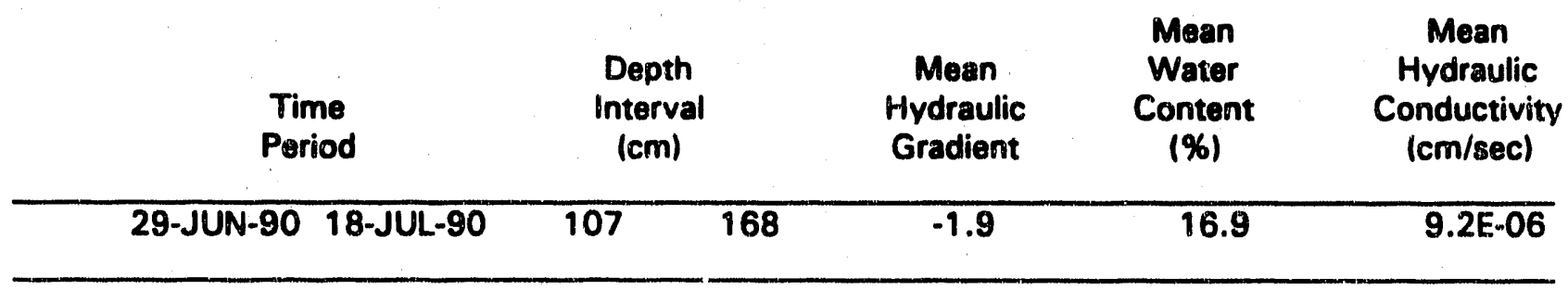


Table 5.2.1.5 Hydrologic data analyses by date for cell 1 replication 1 in the ESL.

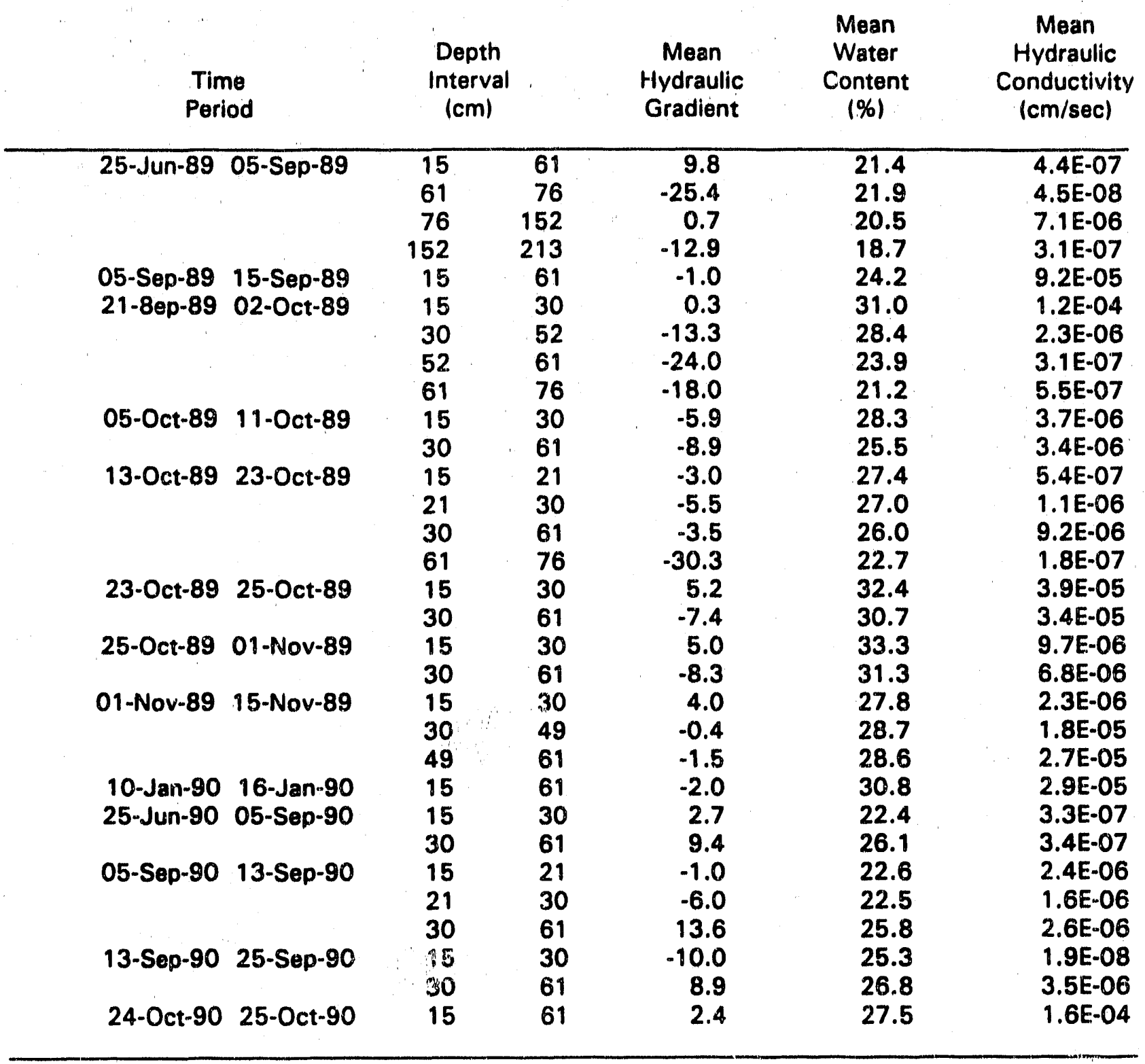


Table 5.2.1.6 Hydrologic data analyses by date for cell 1 replication 2 in the ESL.

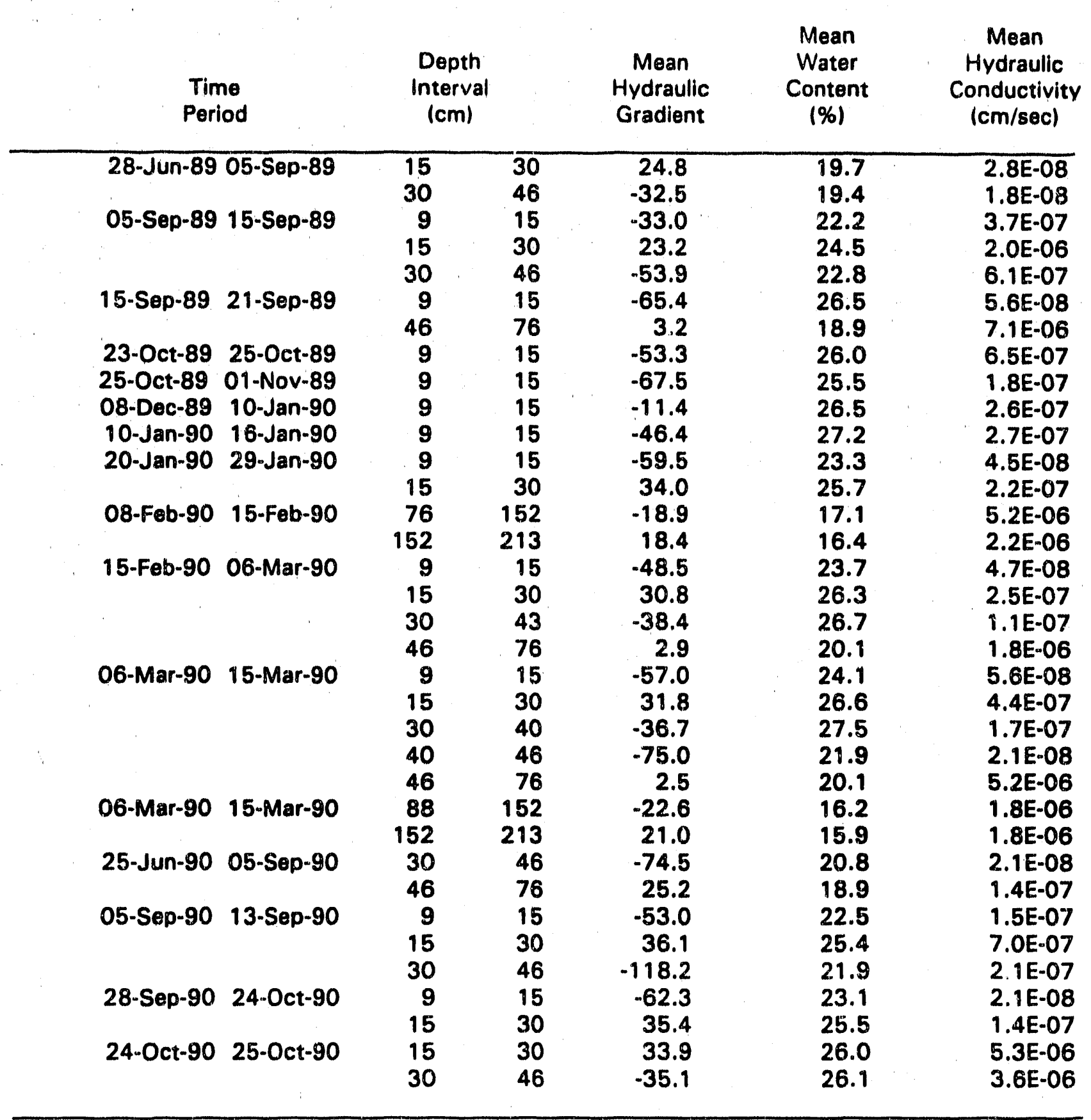


Table 5.2.1.7 Hydrologic data analyses by date for cell 1 replication 3 in the ESL.

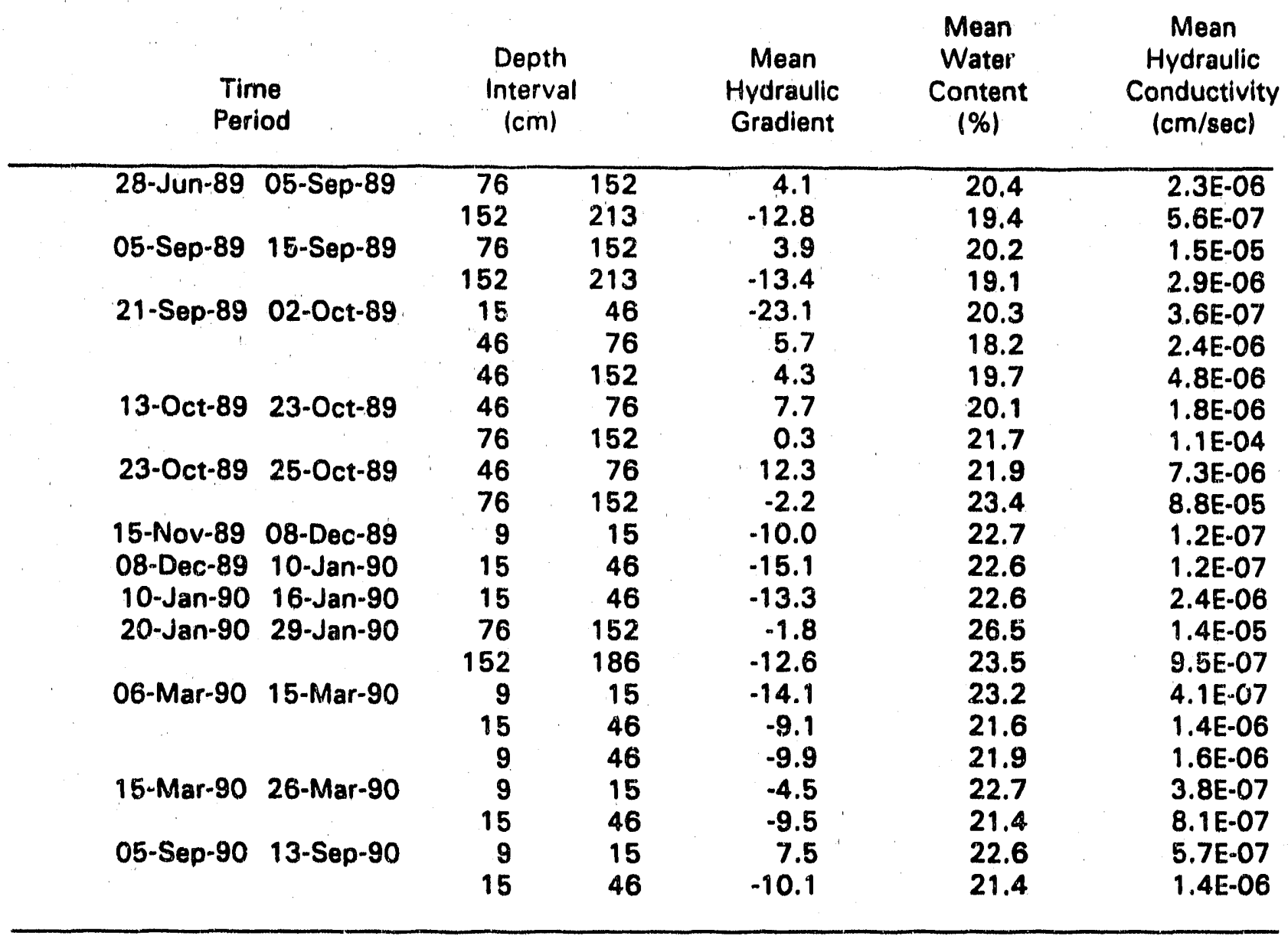


Table 5,2,1.8 Hydrologic data analyses by date for cell 2 replication 1 in the ESL.

\begin{tabular}{|c|c|c|c|c|c|}
\hline $\begin{array}{l}\text { Time } \\
\text { Period }\end{array}$ & $\begin{array}{l}\text { De } \\
\text { Int } \\
\text { Io }\end{array}$ & & $\begin{array}{c}\text { Mean } \\
\text { Hydraulic } \\
\text { Gradient }\end{array}$ & $\begin{array}{c}\text { Mean } \\
\text { Water } \\
\text { Content } \\
(\%)\end{array}$ & $\begin{array}{c}\text { Mean } \\
\text { Hydraulic } \\
\text { Conductivity } \\
(\mathrm{cm} / \mathrm{s} \theta \mathrm{c})\end{array}$ \\
\hline 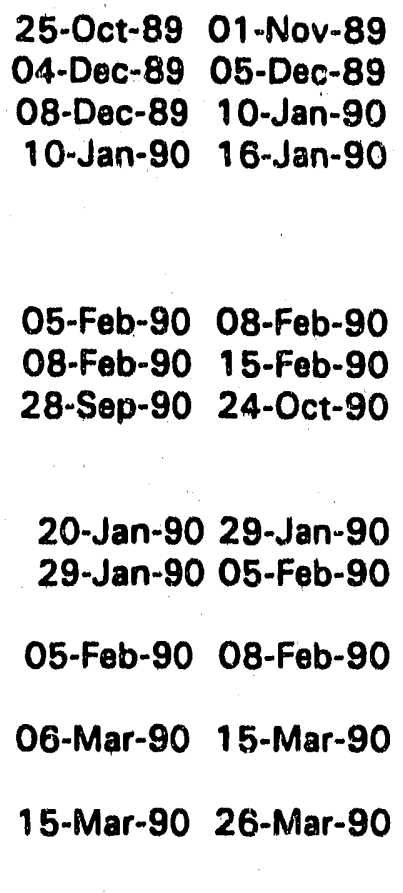 & $\begin{array}{l}30 \\
46 \\
46 \\
46 \\
61 \\
76 \\
61 \\
46 \\
46 \\
9 \\
30 \\
46 \\
76 \\
30 \\
76 \\
30 \\
76 \\
30 \\
76 \\
30 \\
76\end{array}$ & $\begin{array}{r}46 \\
61 \\
61 \\
61 \\
76 \\
213 \\
213 \\
61 \\
61 \\
30 \\
46 \\
61 \\
152 \\
76 \\
152 \\
76 \\
152 \\
76 \\
152 \\
76 \\
152\end{array}$ & $\begin{array}{r}r 4.3 \\
14,4 \\
12.8 \\
4.4 \\
-2.2 \\
-4.3 \\
-4.1 \\
20.1 \\
19.6 \\
17.1 \\
21.9 \\
24.6 \\
-5.2 \\
-5.6 \\
-2.9 \\
-4.8 \\
-3.6 \\
-2.5 \\
-4.5 \\
-2.5 \\
-3.4\end{array}$ & $\begin{array}{l}29.4 \\
30.3 \\
30.1 \\
32.4 \\
33.7 \\
28.2 \\
28.7 \\
30.7 \\
31.3 \\
19.7 \\
24.0 \\
32.1 \\
26.8 \\
28.8 \\
25.2 \\
29.8 \\
25.9 \\
29.2 \\
25.9 \\
26.7 \\
24.7\end{array}$ & $\begin{array}{l}1.8 \mathrm{E}-06 \\
1.6 \mathrm{E}-06 \\
1.8 \mathrm{E}-07 \\
4.4 \mathrm{E}-06 \\
1.0 \mathrm{E}-05 \\
3.1 \mathrm{E}-05 \\
3.8 \mathrm{E}-05 \\
1.7 \mathrm{E}-06 \\
1.1 \mathrm{E}-06 \\
2.9 \mathrm{E}-07 \\
4.7 \mathrm{E}-07 \\
3.4 \mathrm{E}-07 \\
8.3 \mathrm{E}-06 \\
9.0 \mathrm{E}-06 \\
2.0 \mathrm{E}-05 \\
4.1 \mathrm{E}-05 \\
6.3 \mathrm{E}-05 \\
4.1 \mathrm{E}-05 \\
1.8 \mathrm{E}-05 \\
9.9 \mathrm{E}-06 \\
6.6 \mathrm{E}-06\end{array}$ \\
\hline
\end{tabular}




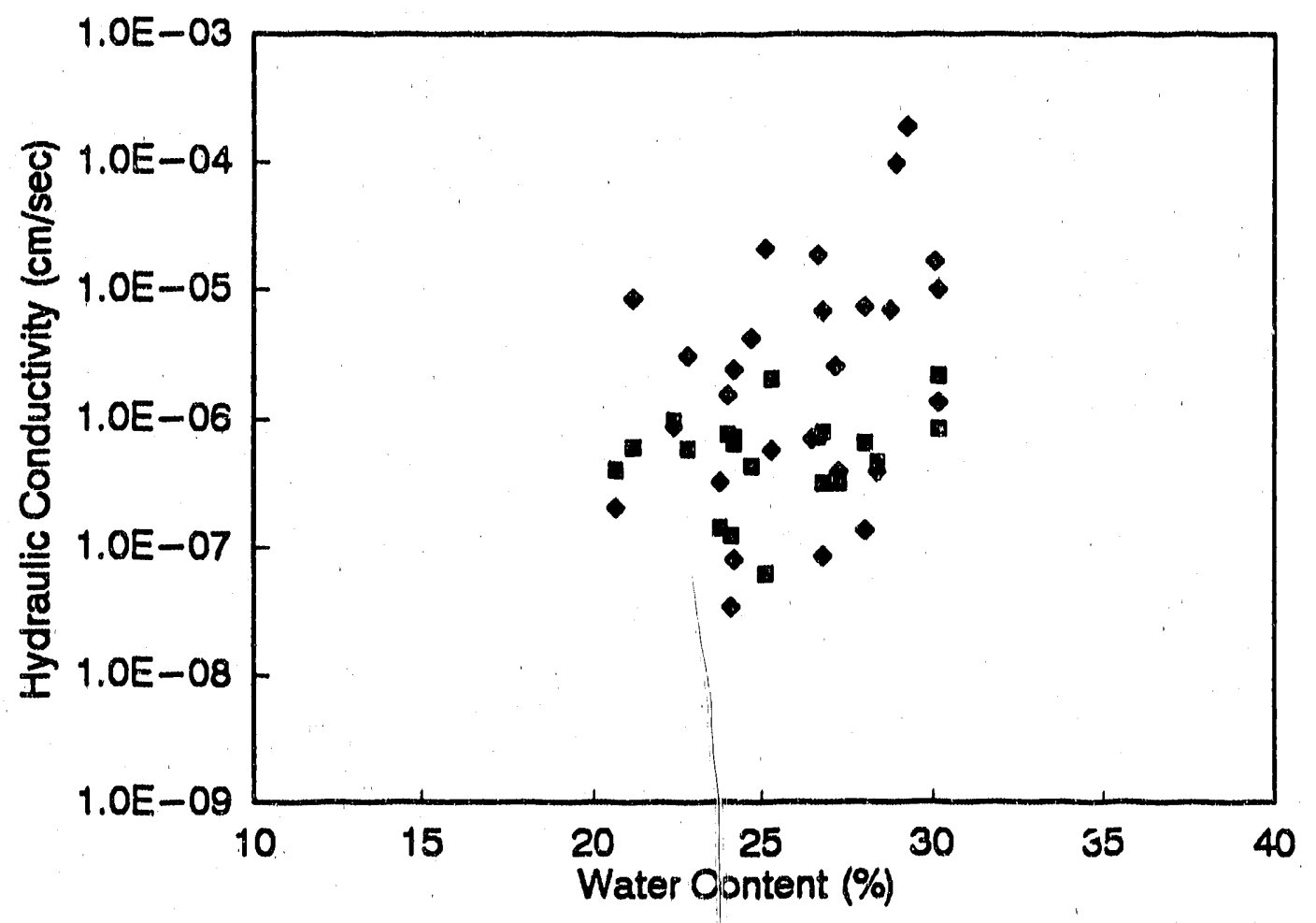

- Rep-1 Rep-2

Figure 5.2.1.1 Unsaturated hydraulic conduct:vity versus water content $\left(\theta_{v}\right)$ for cell 1 at RBOSC. 


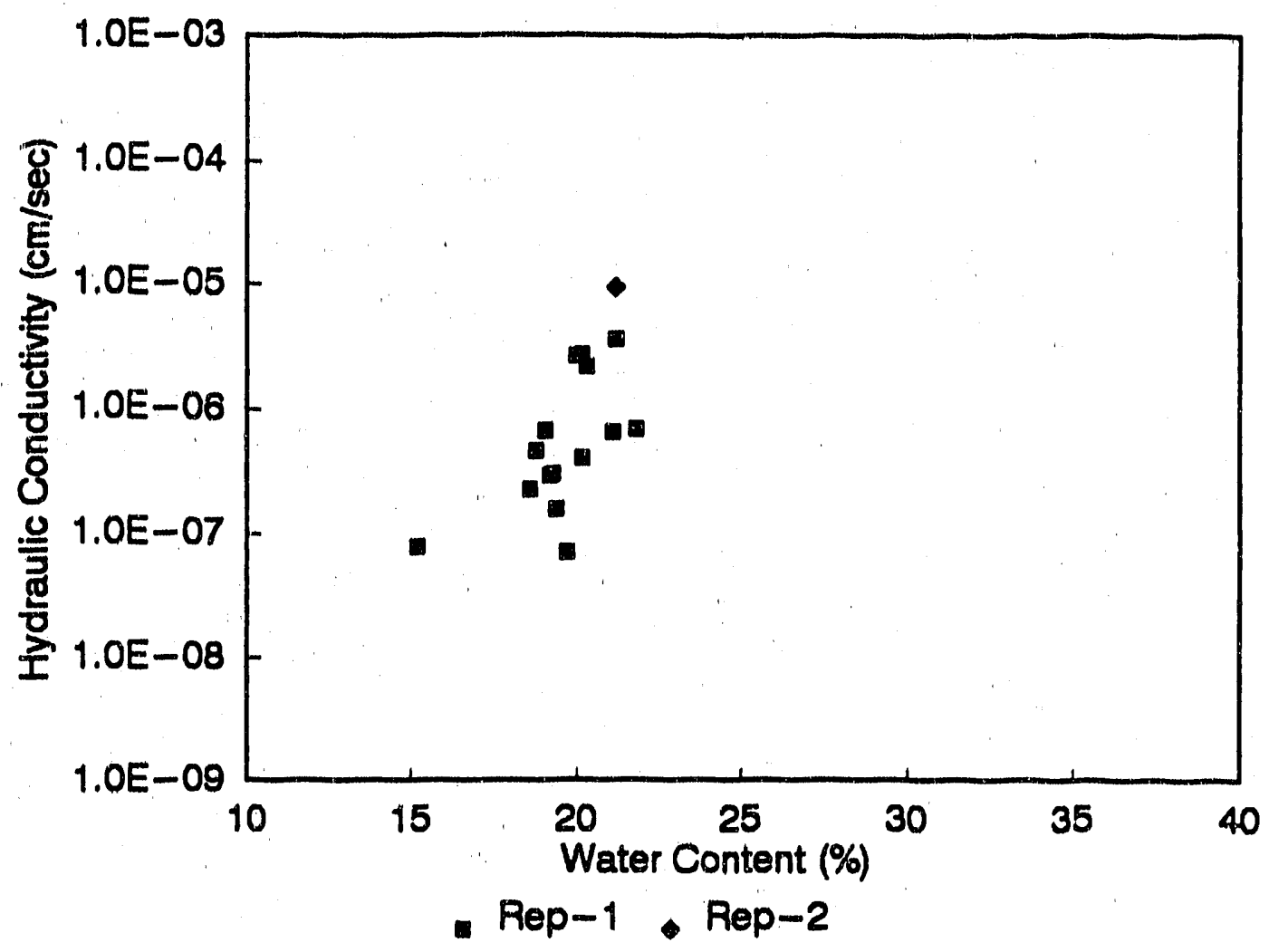

Figure 5.2.1.2 Unsaturated hydraulic conductivity versus water content $\left(\theta_{v}\right)$ for cell 2 at RBOSC. 


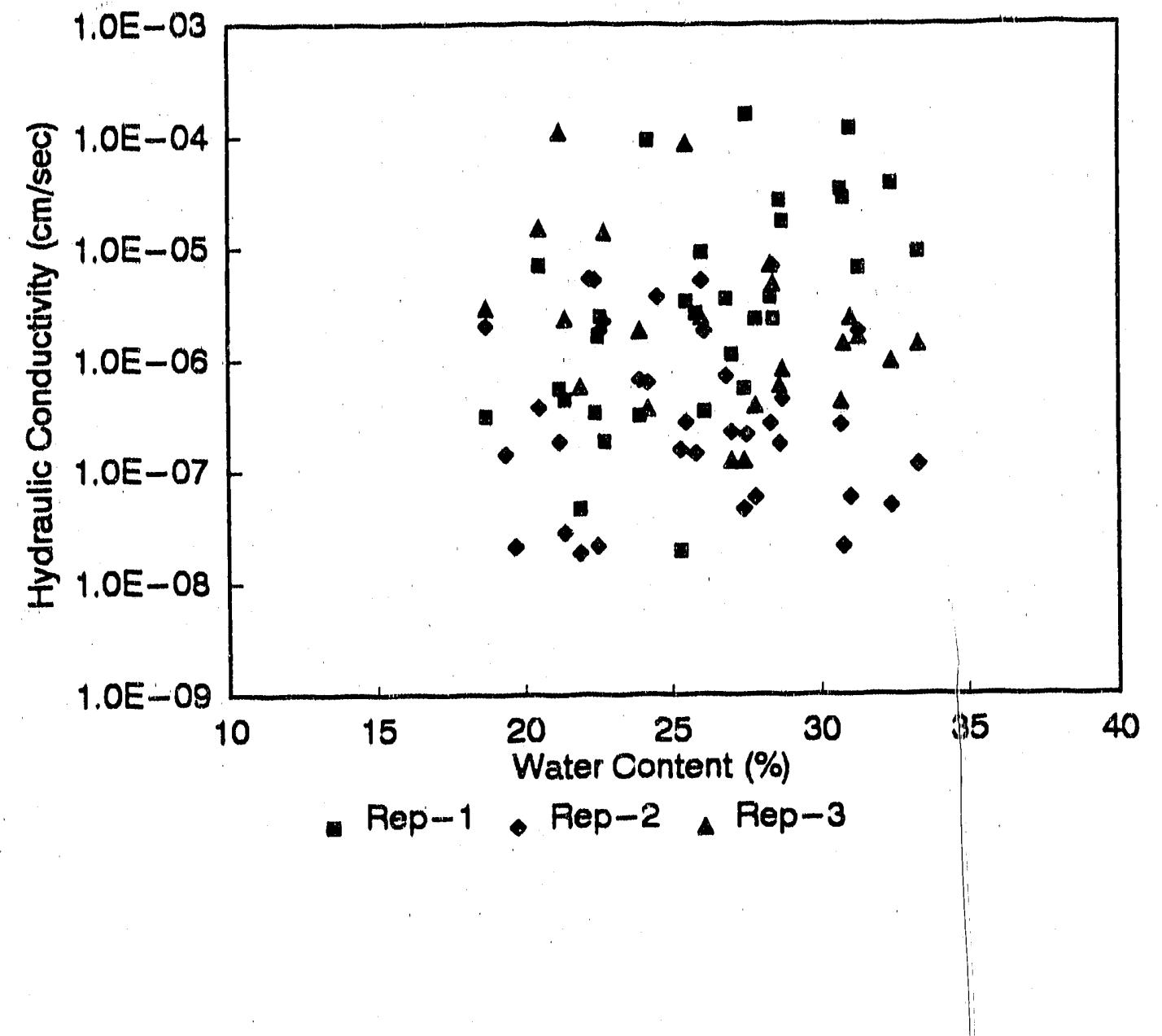

Figure 5.2.1.3 Unsaturated hydraulic conductivity versus water conter $\left(\theta_{v}\right)$ for cell 1 in the ESL. 


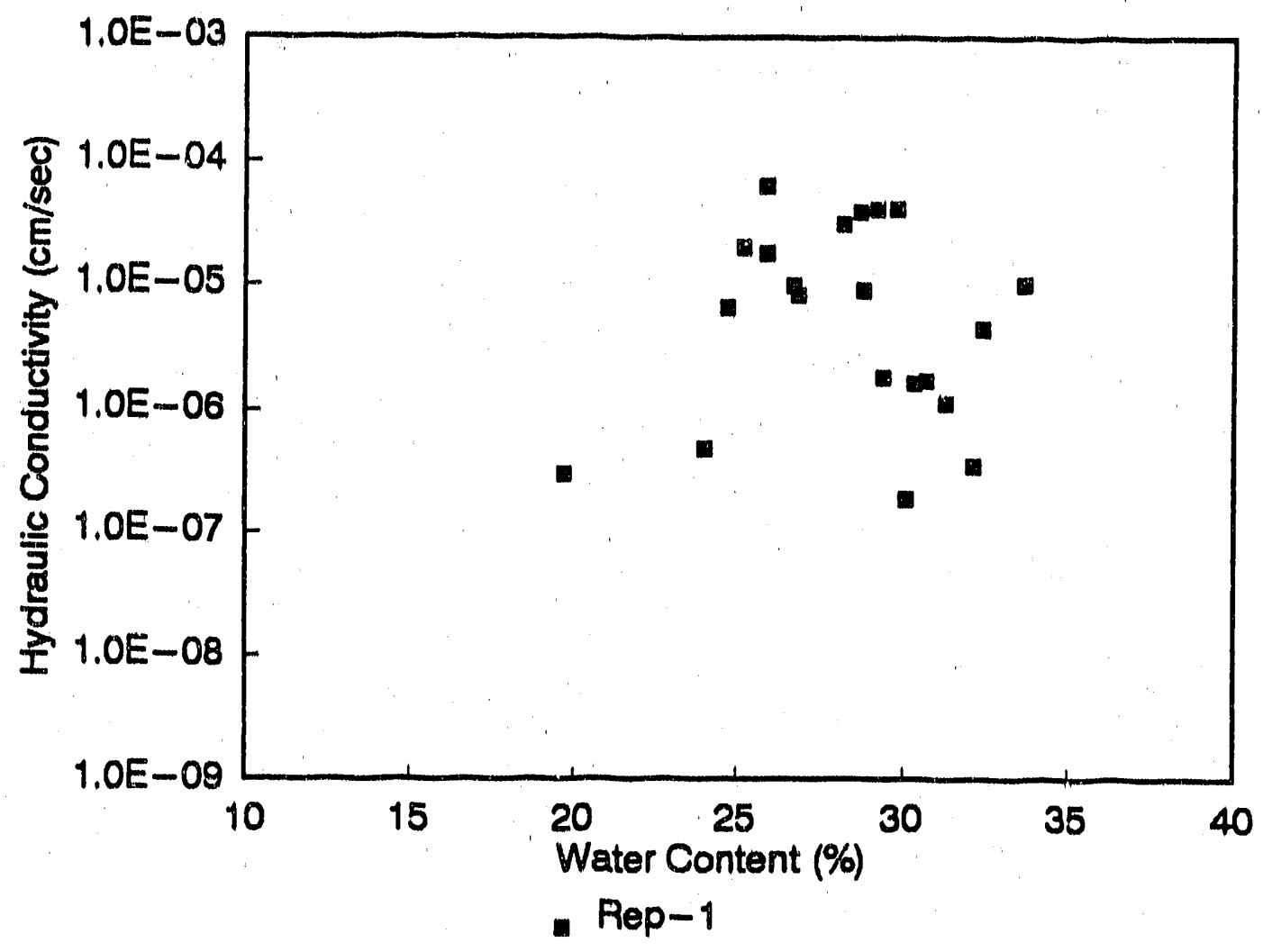

Figure 5.2.1.4 Unsaturated hydraulic conductivity versus water content $\left(\theta_{v}\right)$ for cell 2 in the ESL. 


\subsection{COMPUTER MODELING PROGRAM}

\subsubsection{HYDROLOGIC MODELING}

UNSAT1 was the only hydrogeochemical code selected from the set of one-dimensional codes because of its avallability, ease to run and ability to handle multiple layers. Two dimensional codes selected for evaluation were FEMWATER/FEMWASTE, UNSAT2, and SATURN. FEMWATER/FEMWASTE and UNSAT2 both use a finite element design for their solutions. They were selected because of their general availability and because they have been tested using solid waste material under large disposal scenarios. These codes are both hydrogeochemical codes which can simulate the flow of the leachate and can monitor solute migration. The SATURN code is also a finite element code which can simulate the flow and transport of solute in an unsaturated porous media.

Table 5.3.1.1 lists geochemical codes evaluated and reasons for their selection or rejection. Geochemical codes that predict the chemistry of the leachate material under given conditions and which are readily available are GEOCHEM and MINTEO. GEOCHEM and MINTEO were selected because of their availabilicy and capability of handling more species than other codes available, as well as the hydrogeochemical code selected above.

The development of the hydrogeochemical code(s) for use in the evaluation of the Iysimeter data being obtained under this project is currently ongoing and will be completed as a part of the two year extension of this project. The evaluation must be done during this extension because the data for comparison with the model will only be available from data being collected as a part of the contract extension. The preliminary evaluation of the computer code FEMWATER/FEMWASTE using hydrological data developed as a part of this project has been completrod and runs have been made with the model but data is not available at present to evaliate and calibrate the model to Iysimeter conditions. 
Table 5.3.1.1 Geochemical codes evaluated and reasons for selection or rejection.

Model Selection Reasoning

GEOCHEM Yo

Avallable in the public domain. Documentation marginal but acceptable. Recently updated with new and improved speciation coefficients. Database probably the largest available.

MINTEO Yos

Available in the public domain. Well documented. Includes adsorption analysis. Niodular construction. Database is very well documented and is one of the largest available.

EQUILIB No

EPRI proprietary code. Well documented. Models precipitation but not adsorption. Database quite extensive and reasonably well documented. Can use other databases. Method of solution involves unique elements.

EQ3/EQ6

No

Publicly avallable. Documentation available for $\mathrm{EQ} 3$ only. Contains precipitation analysis but no adsorption analysis.

CHEMIST No

Publicly available. Old and very inadequately documentation. No precipitation/adsorption. No unique modeling. 


\subsection{SUMMARY}

This report discusses and summarizes results from scientific efforts conducted in this research program between October 1986 and March 1991. The research program combines bench scale testing with a large scale lysimeter research program. This is an interim project report which presents final results from task 8 arid objectives which have been concluded to date, and partial/interim results from tasks still in progress or partially completed,

Results from the bench scale research program, primarily designed to describe the initial physical, chemical and hydrologic properties of the Lurgi processed oil shale, are principally complete and presented in this report. These data include potential leachate cheinistry (Objective 2.11, mechanical and constitutive properties such as grain size distribution, Atterberg limits, moisture density relationships, shear strength, and saturated and unsaturated hydraulic conductivity (Objectives 1.1 and 3.1 ).

Results which have been presented in this report from the large scale lysimeter research program and the computer modeling research program are interim or partially complete at this date. These data include in situ hydrologic analyses for infiltration, flux and hydraulic properties (Objectives 1.2, 1.3 and 1.4), in situ chemical analyses (Objective 2.2, 2.3 and 2.4), in situ stress analysis, and those from the computer model research program (Objective 4.0 and 5.0 ). Final results from these research programs are dependent on completion of all in situ tests and the final destructive sampling of the processed shale in the lysimeters at the conclusion of the research program.

A complete discussion and presentation of conclusions from this research program can not. be presented at this time, however, the following discussion consolidates and summarizes the results presented in this report: 
The design and construction of large scale engineered waste embankments must result in cost effective struotures that are physically stable. while preventing the release of potentially harmful leachates or other effluents. The physical stability must be sufficient to prevent mass movements such as landslides and depends to a large degree on the shear strength of the processed shald. Rothwell (1989) demonstrated the application of shear strength properties of processed shale to slope stability analysis.

Several different scenarios have been proposed for the construction of oll shale waste embankments in the Piceance Basin (Miller 1987). These fall into two general categories: 1) canyon fills at the heads of canyons and 2) embankments on the tops of flat mesas. In either scenario, physical stability must be provided by making sure that the material has adequate shear strength for the slope angles and for the loading conditions that will exist during the construction, long-term, and transient stages of the life of the embankment. During construction, the undrained or short-term strength properties of the processed shale are the appropriate parameters for analyzing slope stability using limit equilibrium methods. The results of undrained triaxial tests on the Lurgi processed spent shale of this study yield a friction angle of 14 degrees and a cohesion of $162 \mathrm{kNim}^{2}$. Alternatively, the unconfined compressive sirength presented by this study can be used to evaluate undrained loading and may be more appropriate for unsaturated conditions. This study and others have demonstrated that the unconfined compressive strength of Lurgi-processed Western oil shale is highly dependent upon initial water content and compaction effort. To exploit the cementing characteristics, it is recommended that combusted shales be mixed with water sufficient to obtain maximum dry densities. Figure 5.1.2.2.1 can be used as a guide for combusted shales similar to the Lurgi processed shale of this study. Figure 5.1.2.3.3 can be used to determine the resulting unconfined compressive strength. 
For the long-term stage of embankment life, when the final geometry and loads have been established, the drained shear strength is appropriate for analyzing slope stability. The results of twenty-five consolidated drained triaxial tests on samples prepared and compacted at 15 percent water content yield a drained friction angle of 38 degrees and a cohesion of $12 \mathrm{kN} / \mathrm{m}^{2}$. The friction angle was found to decrease with increasing confining stress. This decrease in friction angle with increasing overburden stress can be taken into account by decreasing the friction angle by one degree for every $2,000 \mathrm{kN} / \mathrm{m}^{2}$ of effective overburden stress.

Transient loading conditions may occur during either the construction or long-term stages if the embankment is subjected to an earthquake or blasting (e.g., due to mining operations). The shear strength of combusted shale under dynamic loading conditions should be evaluated to provide a thorough analysis of embankment stability. Evaluation of dynamic properties and modeling of embankment behavior under dynamic loads will be conducted during the next phase of this research program.

To minimize the flow of leachate from waste embankments, it is desirable to minimize the hydraulic conductivity of the material. Hydraulic conductivity can range from approximately $10^{-3}$ $\mathrm{cm} / \mathrm{sec}$ to $10^{-8} \mathrm{~cm} / \mathrm{sec}$, and depends upon the water content used for mixing and curing, curing time, the compactive effort and resulting density. If mixed and cured at water contents below approximately 25 percent, aggregated particles consisting of a cemented outer shell are formed, resulting in a coarse texture with high porosity. This material yields relatively high hydraulic conductivities. If mixed, compacted, and cured at water contents over 25 percent, the processed shale hardens into a relatively impermeable material with hydraulic conductivities on the order of $10^{-8} \mathrm{~cm} / \mathrm{sec}$. The effect of compaction effort on the hydraulic conductivity of samples cured at room temperature and humidity was evaluated and it was found that increasing the dry density from $12.5 \mathrm{kN} / \mathrm{m}^{3}$ to $14.4 \mathrm{kN} / \mathrm{m}^{3}$ decreases the conductivity by three orders of magnitude (from $10^{-3}$ to $10^{.6} \mathrm{~cm} / \mathrm{sec}$ ), as shown in Figure 5.1.2.4.1. 
The cost and availability of water in the arid regions where Western oil shale deposits exist may make it cost prohibitive to mix the processed shale with enough water to optimize the cementing characteristics. In this case, compaction at water contents below optimum, will yield lower strengths and higher hydraulic conductivities. The design of stable embankments must account for lower shear strengths by utilizing lower slope angles. For very large embankments, possibly covering areas over 1 mile square, this could increase the cost of disposal by increasing land requirements. A tradeoff between the cost and availability of water and the cost of the land required or available for disposal will then be necessary.

The control of leachate from waste embankments may not require that the entire embankment be "impermeable". Strategically located layers of low hydraulic conduçivity can be created within the embankment by mixing at higher water contents and curing the processed shale. Modeling of fluid flow through the embankment, taking into account precipitation, evaporation, infiltration, runoff, groundwater conditions, geometry of the embankment, and hydraulic conductivity of the processed shale, will be required to determine the optimum location and thickness of designed "impermeable" layers.

One factor which has not been taken into account in any previously published studies is the possible change in material properties of processed shale over long periods of time. For example, it is not known whether cementitious bonds will break down or deteriorate with time under field conditions which include many cycles of freeze/thaw or wet/dry. This possible deterioration could cause the hydraulic conductivity to increase and the strength to decrease significantly. The hydraulic conductivities of several compacted clay liners for landfills have been observed to be 10 to 1,000 times greater than values obtained from laboratory permeability tests (Daniel 1984). Laboratory samples do not contain a representative distribution of fractures, fissures, or other geohydrologic variations that may be present in commercial embankments. Fractures or cracks may be a problem using hydraulic barriers of compacted processed shale 
because the material is quite brittle when cemented. In situ measurements on large samples of processed shale in field test embankments subject to weathering are recommended to address these potential long term effects.

The effects of wet-dry and freeze-thaw weathering on the strength and hydraulic conductivity of laboratory samples of Lurgi processed shale are inconclusive at this time. Further studies aimed at 2 ddressing this problem are in progress.

Finally, the most cost-effective and optirnum methods of waste embankment design and construction must also be based upon experience. All the required data and information is not available since no large, full-scale commercial waste embankment of Lurgi processed shale has been constructed to date. First generation projects should be based upon the laboratory and field information that is available, experience with similar materials (such as coal waste), and good judgment. 


\subsection{LITERATURE CITED}

Annual Book of ASTM Standards. 1985. Vol. 04.08, American Society for Testing and Materials, Philadelphia, PA.

Brown, M., and Brown, T. 1991. Solution Chemistry and Mineralogy of Spent Shale Samples Subjected to Weathering Tests. Report WRI-91-R040, Western Research Institute, L.aramie, WY, $17 \mathrm{p}$.

Boynton, S.S., and D.E. Daniel. 1985. Hydraulic conductivity tests on compacted clay. J. Geotech. Eng., ASCE, 111(4):465-478.

Culbertson, W.J., Jr., Nevens, T.D., and R.D. Hollingshead. 1970. Disposal of oil shale ash. Quart. Colorado School of Mines, 65(4):89-132.

Daniel, D.E. 1984. Predicting hydraulic conductivity of clay liners. J. Geotech. Eng., ASCE, 110(2):285-300.

Eglinton, M.S. 1987. Concrete and its chemical behavior. London, Thomas Telford Ltd, 136 p.

Everett, L.G., L.G. Wilson, and E.W. Hoylman. 1984. Vadose zone monitoring for hazardous waste sites. Noyes Data Corporation, Park Ridge, Nevw Jersey, USA, 358 p.

Marcus, D., Sangrey, D.A., and S.A. Miller. 1985. Effects of cementation process on spent shale stabilization. Trans. Soc. Mining Eng., 278:1225-1232.

Miller, G.A., 1987. Development of the oil shale and associated minerals. In Oil shale, water resources, and valuable minerals of the Piceance Basin, Colorado: the challenge and choices of development. U.S.G.S. Prof. Paper 1310, p. 29-42.

Prien, C.H. 1980. Oil Shale Resources. In Environmental perspective on the emerging oil shale industry, E.R. Bates and T.L. Thoem, eds., p 2-11. US Environmental Protection Agency Report EPA-600/2-80-205a.

Reeves, T.L. Rainfall simulation and hydrologic monitoring of a combusted western oil shale in large scale lysimeters. In Proceedings of the 1989 Eastern Oil Shale Symposium, D.J. Lazar, ed, p 394-401. Institute for Mining and Minerais Research, University of Kentucky, Lexington.

Rothwell, R.A. 1989. Initial geotechnical properties of a retorted and combusted oil shale solid waste. M.S. thesis, University of Wyoming Dept. of Civil Eng., Laramie, WY, 168 p.

Sri Ranjan, R. 1989. Water movement in Lurgi-combusted oil shale affected by time-dependent hydraulic properties: PhD dissertation, Colorado State University Dept. of Agr. and Chem. Eng., Fort Collins, CO, 88 p. 
Sri Ranjan, R., McWhorter, D.B., and G.H. Watson. 1989. Hydraulic properties of combusted oil shale affected by cementitious reactions. Draft manuscript provided by Rio Blanco Oil Shale Co., Inc. 

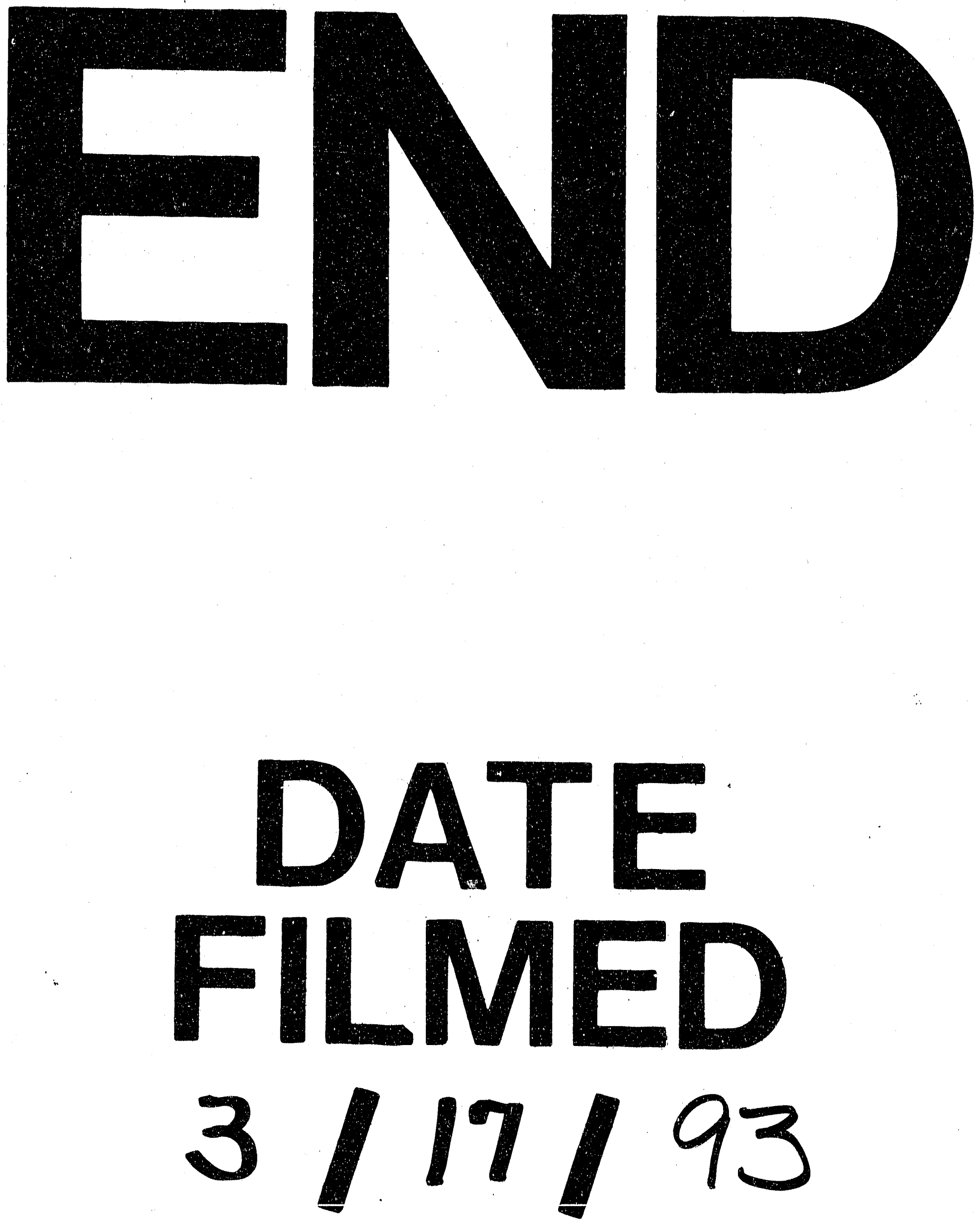
